Face Page - DOE Form F 241.3 
Final Technical Report

\section{Near-Net Shape Fabrication Using Low-Cost Titanium Alloy Powders}

DOE Award Number:

Project Period:

Principal Investigators:

Performing Organization:

Team Members:

Report Date:
DE-EE0003480

August 16, 2010 - December 31, 2011

Dr. David M. Bowden

314-232-1859

david.m.bowden@boeing.com

Dr. William H. Peter

865-241-8113

peterwh@ornl.gov

The Boeing Company

Boeing Research \& Technology

P. O. Box 516

St. Louis, MO 63166

Oak Ridge National Laboratory (ORNL) APCI, Inc.

31 March, 2012 
This report is based upon work supported by the U. S. Department of Energy under Award No. DE-EE0003840.

Disclaimer: "Any findings, opinions, and conclusions or recommendations expressed in this report are those of the author(s) and do not necessarily reflect the views of the Department of Energy"

Document Availability: Reports are available free via the U.S. Department of Energy (DOE) Information Bridge Website: http://www.osti.gov/bridge

Reports are available to DOE employees, DOE contractors, Energy Technology Data Exchange (ETDE) representatives, and Informational Nuclear Information System (INIS) representatives from the following source:

Office of Scientific and Technical Information

P.O. Box 62

Oak Ridge, TN 37831

Tel: (865) 576-8401

FAX: (865) 576-5728

E-mail: reports@osti.gov

Website: http://www.osti.gov/contract.html 


\section{TABLE OF CONTENTS}

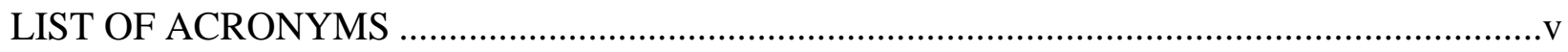

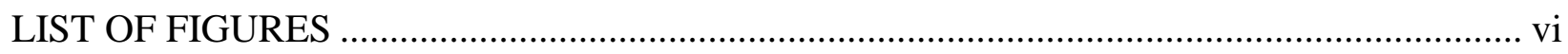

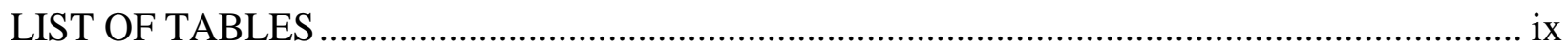

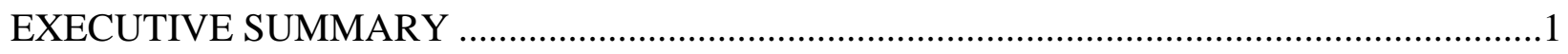

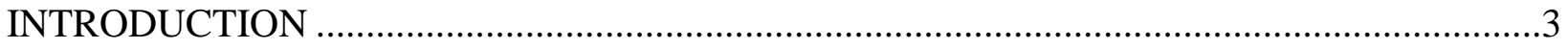

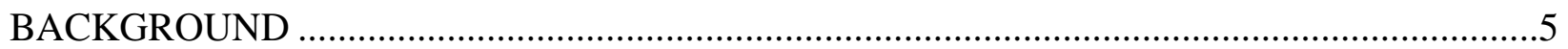

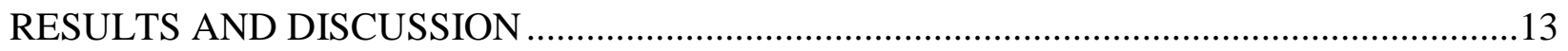

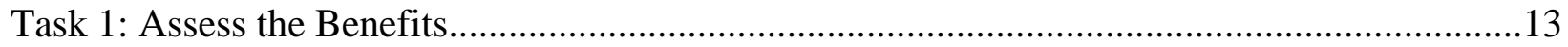

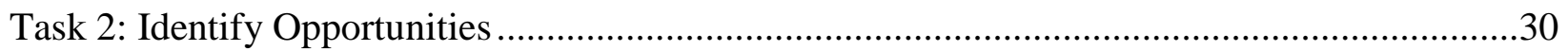

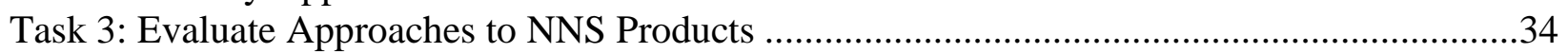

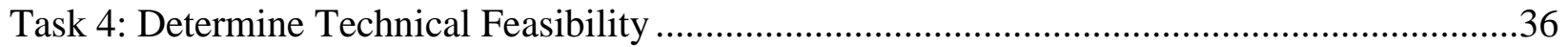

Task 5: Define a Viable Process ...............................................................................................61

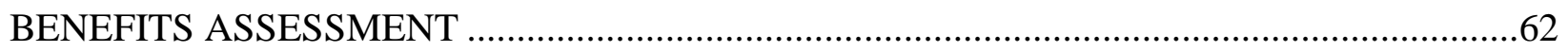

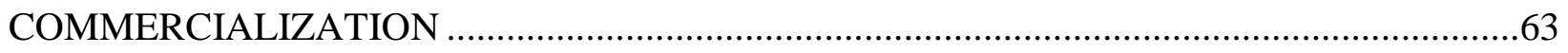

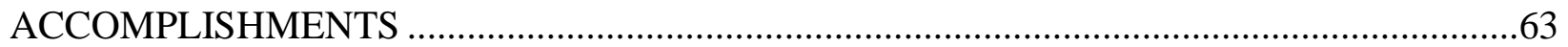

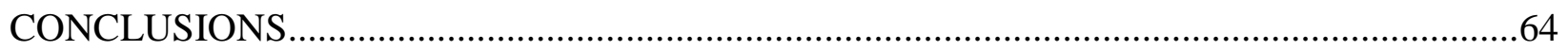

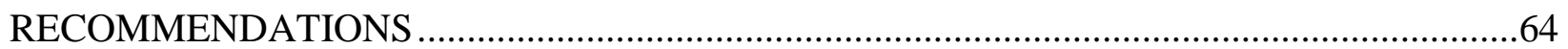

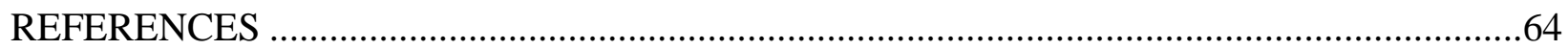




\section{LIST OF ACRONYMS}

PM Powder Metallurgy

ITP International Titanium Powder, Ltd

CIP Cold Isostatic Pressing

HIP Hot Isostatic Pressing

HDH Hydride-dehydride powders

BE Blended elemental powders 


\section{LIST OF FIGURES}

Figure 1. Titanium usage in commercial aircraft as a percentage of the Operating Empty Weight (OEW)

Figure 2. Material distribution for the Boeing 787 aircraft 4

Figure 3. Cost of conventional titanium mill products 6

Figure 4. Schematic of the Armstrong Process...............................................................

Figure 5. Titanium powder produced by the Armstrong Process .7

Figure 6. Schematic of the FFC Cambridge Process .......................................................

Figure 7. Cost analysis for the Armstrong and Cambridge Processes .....................................

Figure 8. Near Net Shaped machining preform fabrication............................................. 10

Figure 9. Estimated machining costs as a function of finished part weight for three different buy-to-fly $(\mathrm{B} / \mathrm{F})$ ratios .17

Figure 10. NNS preform and finished part cost as a function of $\mathrm{B} / \mathrm{F}$ ratio.......

Figure 11. Relationship between NNS machining preform cost and finished part cost reduction as a function of $\mathrm{B} / \mathrm{F}$ ratio .30

Figure 12. Relationship between NNS machining preform cost and finished part Cost reduction as a function of $\mathrm{B} / \mathrm{F}$ ratio when the benefits of chip recycling are Factored into cost reduction .32

Figure 13. Distribution of titanium parts as a function of material product form by number of parts and total weight of parts 31

Figure 14. Major Titanium Part Types for NNS Preform Technology

Figure 15. HDH and BE powder metallurgy plate and bar stock used for joining/assembly trials in technical feasibility studies.

Figure 16. Yield analysis for HDH titanium powder HIP cylinders. .36

Figure 17. Examples of HDH titanium HIP billets and cylindrical billets after can removal ......36

Figure 18. Cambridge process titanium from Metalysis Ltd, Rotherham, UK. 37

Figure 19. Cambridge process titanium .37 
Figure 20. Chemical analysis of pure titanium produced by the Cambridge process.

Figure 21. Cambridge titanium after consolidation by vacuum hot pressing..... .38

Figure 22. Laser welds on PM Ti-6Al-4V plate and extrusion samples.

Figure 23. X-ray photographs of laser welds in BE Ti-6Al-4V mill stock produced at and $160 \mathrm{in} / \mathrm{min}$ linear speed.

Figure 24. X-ray photographs of laser welds in HDH Ti-6Al-4V mill stock produced at 20 and $160 \mathrm{in} / \mathrm{min}$ linear speed

Figure 25. Effect of welding speed on weld zone characteristics in BE Ti-6Al-4V plate.

Figure 26. Effect of welding speed on weld zone characteristics in HDH Ti-6Al-4V .

Figure 27. GTA welds and cross sectional views of PM HDH Ti-6Al-4V plate

Figure 28. GTA welds in experimental Armstrong Ti-6Al-4V plate.

Figure 29. Cross section of GTA welded Armstrong Ti-6Al-4V Plate.

Figure 30. Electron beam welded Armstrong Ti-6Al-4V plate.

Figure 31. Optical micrographs of EB welds in Armstrong Ti-6Al-4V plate

Figure 32. Electron Beam (EB) Weld Titanium Test Specimens .48

Figure 33. Electron beam welded Armstrong CP Ti plate.

Figure 34. Electron beam welded Armstrong Ti-6Al-4V PM plate

Figure 35. EB welded HDH Ti-6Al-4V PM plates.

Figure 36. EB welded commercial CP Ti and Ti-6Al-4V plates. .50

Figure 37. Results of temperature-programmed mass spectrometry (TPD-MS) of Armstrong CP Ti powder showing gases driven off during continuous heating.

Figure 38. Results of temperature-programmed mass spectrometry (TPD-MS) of Armstrong CP Ti powder showing gases driven off during continuous heating (expanded scale to show details).

Figure 39. Results of temperature-programmed mass spectrometry (TPD-MS) of Armstrong CP Ti powder showing gases driven off during step heating.... .54

Figure 40. Results of temperature-programmed mass spectrometry (TPD-MS) 
of Armstrong CP Ti powder showing gases driven off during step heating (expanded scale to show details)...

Figure 41. Arc melting experiments of powder metallurgy titanium samples .........................56

Figure 42. Linear Friction Welded (LFW) HDH Ti-6Al-4V specimens .................................59

Figure 43. Processing of titanium powders into mill products ..............................................61 


\section{LIST OF TABLES}

Table 1. Estimated Costs of Various Solid State Mill Products

Produced from Armstrong Powder .11

Table 2. Energy Savings Analysis for NNS Titanium Technology 15

Table 3. Estimated Machining Costs as a Function of Finished Part Weight And Buy-to-Fly Ratio, \$ .16

Table 4. Material + Machining Costs as a Function of Buy-to-Fly Ratio, $\$$ 18

Table 5. Effect of Material Price on Cost Savings (Material + Machining \%

Cost Reduction from B/F of 10 to 2 .

Table 6A. Near Net Shape Machining Preform Cost, B/F from 5 to 2.

$30 \%$ of Material + Machining Cost Savings Applied to Preform Fabrication

Table 6B. Finished Part Cost and Raw Material Reductions, B/F from 5 to 2

$30 \%$ of Material + Machining Cost Savings Applied to Preform Fabrication

Table 7A. Near Net Shape Machining Preform Cost, B/F from 5 to 2

$40 \%$ of Material + Machining Cost Savings Applied to Preform Fabrication.

Table 7B. Finished Part Cost and Raw Material Reductions, B/F from 5 to 2

$40 \%$ of Material + Machining Cost Savings Applied to Preform Fabrication.

Table 8A. Near Net Shape Machining Preform Cost, B/F from 5 to 2

$50 \%$ of Material + Machining Cost Savings Applied to Preform Fabrication.

Table 8B. Finished Part Cost and Raw Material Reductions, B/F from 5 to 2

$50 \%$ of Material + Machining Cost Savings Applied to Preform Fabrication.

Table 9A. Near Net Shape Machining Preform Cost, B/F from 5 to 2

$60 \%$ of Material + Machining Cost Savings Applied to Preform Fabrication.

Table 9B. Finished Part Cost and Raw Material Reductions, B/F from 5 to 2

$60 \%$ of Material + Machining Cost Savings Applied to Preform Fabrication.

Table 10A. Near Net Shape Machining Preform Cost, B/F from 5 to 2

$70 \%$ of Material + Machining Cost Savings Applied to Preform Fabrication

Table 10B. Finished Part Cost and Raw Material Reductions, B/F from 5 to 2

$70 \%$ of Material + Machining Cost Savings Applied to Preform Fabrication.... 
Table 11A. Near Net Shape Machining Preform Cost, B/F from 10 to 2

$30 \%$ of Material + Machining Cost Savings Applied to Preform Fabrication

Table 11B. Finished Part Cost and Raw Material Reductions, B/F from 10 to 2

$30 \%$ of Material + Machining Cost Savings Applied to Preform Fabrication

Table 12A. Near Net Shape Machining Preform Cost, B/F from 10 to 2

$40 \%$ of Material + Machining Cost Savings Applied to Preform Fabrication

Table 12B. Finished Part Cost and Raw Material Reductions, B/F from 10 to 2

$40 \%$ of Material + Machining Cost Savings Applied to Preform Fabrication

Table 13A. Near Net Shape Machining Preform Cost, B/F from 10 to 2

$50 \%$ of Material + Machining Cost Savings Applied to Preform Fabrication

Table 13B. Finished Part Cost and Raw Material Reductions, B/F from 10 to 2

$50 \%$ of Material + Machining Cost Savings Applied to Preform Fabrication

Table 14A. Near Net Shape Machining Preform Cost, B/F from 10 to 2

$60 \%$ of Material + Machining Cost Savings Applied to Preform Fabrication

Table 14B. Finished Part Cost and Raw Material Reductions, B/F from 10 to 2

$60 \%$ of Material + Machining Cost Savings Applied to Preform Fabrication

Table 15A. Near Net Shape Machining Preform Cost, B/F from 10 to 2

$70 \%$ of Material + Machining Cost Savings Applied to Preform Fabrication .28

Table 15B. Finished Part Cost and Raw Material Reductions, B/F from 10 to 2

$70 \%$ of Material + Machining Cost Savings Applied to Preform Fabrication

Table 16. Finished Part Material + Machining Costs as a $\mathrm{f}(\mathrm{B} / \mathrm{F})$ Ratio, $\$$

Includes Credit for Recycled Machining Chips@ @3.00/lb.

Table 17. Chemistry of conventional wrought and powder metallurgy Ti-6Al-4V

specimens before and after melting

Table 18. Chemistry of conventional wrought and powder metallurgy Ti-6Al-4V

specimens before and after melting

Table 19. Tensile data for linear friction welded Ti-6Al-4V alloy subscale

performs. Tests performed per ASTM Standard E8 


\section{EXECUTIVE SUMMARY}

Project DE-EE0003480, entitled Near Net Shape Processing of Low-Cost Titanium Alloy Powders (NearNet), was funded by the U.S. Department of Energy, Office of Energy Efficiency and Renewable Energy (EERE), Industrial Technologies Program. This project seeks to develop a transformational approach to large-scale titanium component fabrication enabled by the availability of low-cost titanium powders produced by emerging methods of titanium extraction which dramatically reduces energy consumption and material and fabrication costs.

The use of titanium in commercial aircraft production has risen steadily over the last half century. This trend is driven in large part by the increasing use of composites in aircraft structure to reduce weight and improve fuel efficiency. Titanium, unlike aluminum, is chemically compatible with carbon fiber. It also matches the thermal expansion and strain capability of the composite material better than aluminum. The combined composite and titanium structure results in a corrosion and fatigue resistant airplane, reducing inspection and maintenance costs to the airlines. The aerospace industry currently accounts for $58 \%$ of the domestic titanium market (DOE-ITP Titanium Report 2007).

Roughly a quarter of a million pounds of titanium mill products are used to produce a single Boeing 787 aircraft (including the engines). However, the completed airplane contains only about $37,500 \mathrm{lbs}$ of finished titanium components. The balance, over 200,000 lbs of titanium, is converted to scrap mostly in the form of machining chips produced during fabrication. This inefficient manufacturing approach consumes large quantities of energy-intensive and expensive material. In addition, the amount of machining required to produce finished parts from conventional titanium mill products generates significant costs, since titanium is difficult to machine and requires expensive machine tools.

The Kroll process, which has been used for over 50 years to produce titanium metal from its mineral form, consumes large quantities of energy. And, methods used to convert the titanium sponge output of the Kroll process into useful mill products also require significant energy resources. These traditional approaches result in product forms that are very expensive, have long lead times of up to a year or more, and require costly operations to fabricate finished parts. Given the increasing role of titanium in commercial aircraft, new titanium technologies are needed to create a more sustainable manufacturing strategy that consumes less energy, requires less material, and significantly reduces material and fabrication costs.

A number of emerging processes are under development which could lead to a breakthrough in extraction technology. Several of these processes produce titanium alloy powder as a product. The availability of low-cost titanium powders may in turn enable a more efficient approach to the manufacture of titanium components using powder metallurgical processing. The objective is to define energy-efficient strategies for manufacturing large scale titanium structures using these low-cost powders as the starting material. Strategies include approaches to powder consolidation to achieve fully dense mill products, and joining technologies such as friction and laser welding to combine those mill products into near net shape (NNS) preforms for machining. The near net shape approach reduces material and machining requirements providing for improved affordability of titanium structures. Energy and cost modeling is used to define those 
approaches that offer the largest energy savings together with the economic benefits needed to drive implementation.

We have analyzed the requirements for titanium in the Boeing 787 as a baseline modern commercial aircraft, and identified opportunities for NNS machining performs. Primary candidates for NNS technology are the over 70,000 lbs of titanium components machined from plate stock, representing $60 \%$ of the titanium structure. We performed a benefits analysis to determine the energy and cost benefits of near net shape titanium technology using emerging titanium powder materials. This analysis indicates by the year 2020 , with $50 \%$ of titanium airframe components utilizing NNS technology, 8.29 million pounds of titanium would be removed from the manufacturing cycle annually at current planned production rates, a reduction of $33 \%$ compared to the current state using conventional mill products.

We have established cost targets for NNS machining performs that will enable successful implementation of the NNS approach to capture the energy benefits of the emerging conversion technologies. The preform cost in $\$ / 1 b$ and the percentage of cost reduction possible thru NNS technology are a function of the initial buy-to-fly ratio for a given part. The machining preform price per pound may be significantly higher than the price of conventional titanium mill stock and still produce significant cost reduction for the finished part. The large reduction in raw material and the concurrent reduction in machining more than makes up for the increased material cost on a per pound basis.

Finally, we performed technical feasibility studies to identify the most viable approach to NNS preform fabrication using basic powder metallurgy mill product forms as the building blocks and advanced joining techniques including fusion and solid state joining to assemble these building blocks into machining performs We determined that powder metallurgy based materials are not fusion weldable, and that solid state joining techniques are required for fabrication of NNS machining performs from PM mill products. Thus, solid state joining technologies such as linear friction welding and friction stir welding would be enabling technologies for the NNS preform approach, where the building blocks for NNS shapes are produced from powder. 


\section{INTRODUCTION}

The use of titanium in commercial aircraft has risen steadily over the last 50 years, as illustrated in Figure 1 for Boeing airplane models. This trend is driven in large part by the increasing use of graphite fiber/epoxy resin composite materials in aircraft structure to reduce weight and improve fuel efficiency. Titanium, unlike aluminum, is chemically compatible with carbon fiber, and also better matches the thermal expansion and strain capability of the composite material. The combined composite and titanium design results in a corrosion and fatigue resistant airplane, improving performance and significantly reducing inspection and maintenance costs to the airlines that own and operate the aircraft. The aerospace industry currently accounts for $58 \%$ of the domestic titanium market (DOE-ITP Titanium Report, 2007).

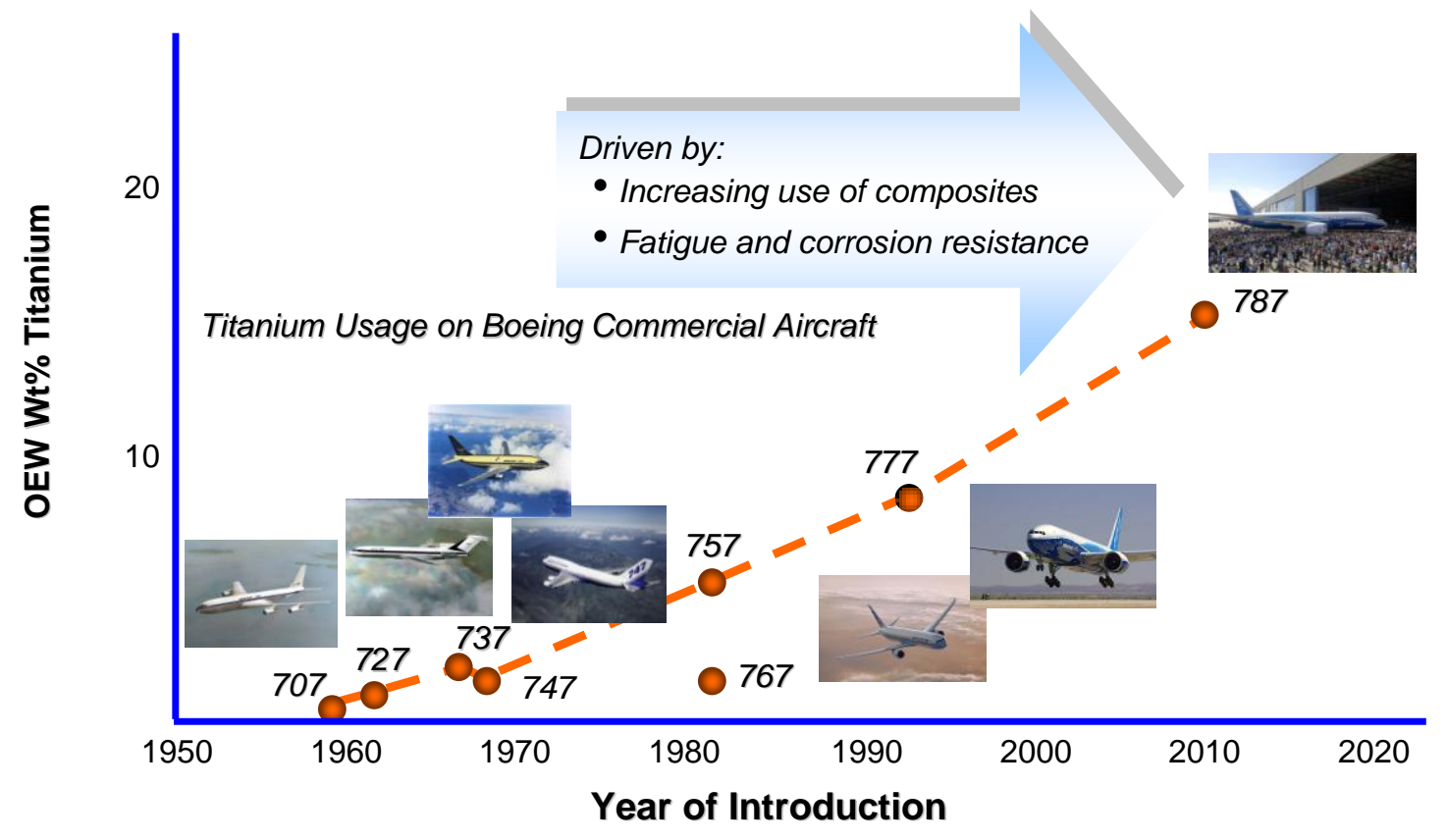

The use of titanium in commercial aircraft has increased steadily over the last 50 years.

Figure 1. Titanium Usage in Commercial Aircraft as a Percentage of the Operating Empty Weight (OEW).

The material distribution for the Boeing 787 is illustrated by the pie chart in Figure 2. This chart shows the material distribution for the airplane as a function of operating empty weight (OEW). Roughly 116,000 pounds of titanium mill products, including plate, bar, extrusions, and forgings, are used to produce the airframe (excluding engines). However, the completed airframe contains only about 19,000 lbs of finished titanium components. The balance of the raw material is scrap, mostly in the form of machining chips generated during part fabrication. The buy-to fly ratio (B/F) for a 787 component, defined as the ratio of the amount of stock material purchased to produce the part to the weight of the finished part, figured from the total vehicle weights above, is on average about 6 to 1 . In specific cases involving complex part designs, the buy-to-fly ratio can be much higher. With an average $\mathrm{B} / \mathrm{F}$ of 6 , about $83 \%$ of the titanium stock used to produce 
a component is reduced to scrap in the form of machining chips. In addition, a significant amount of work and energy is expended to create this scrap. This approach to manufacturing is costly and inefficient, since titanium is expensive, is difficult to machine, and requires expensive machine tools. Machining costs typically represent half of the value of a finished titanium component.

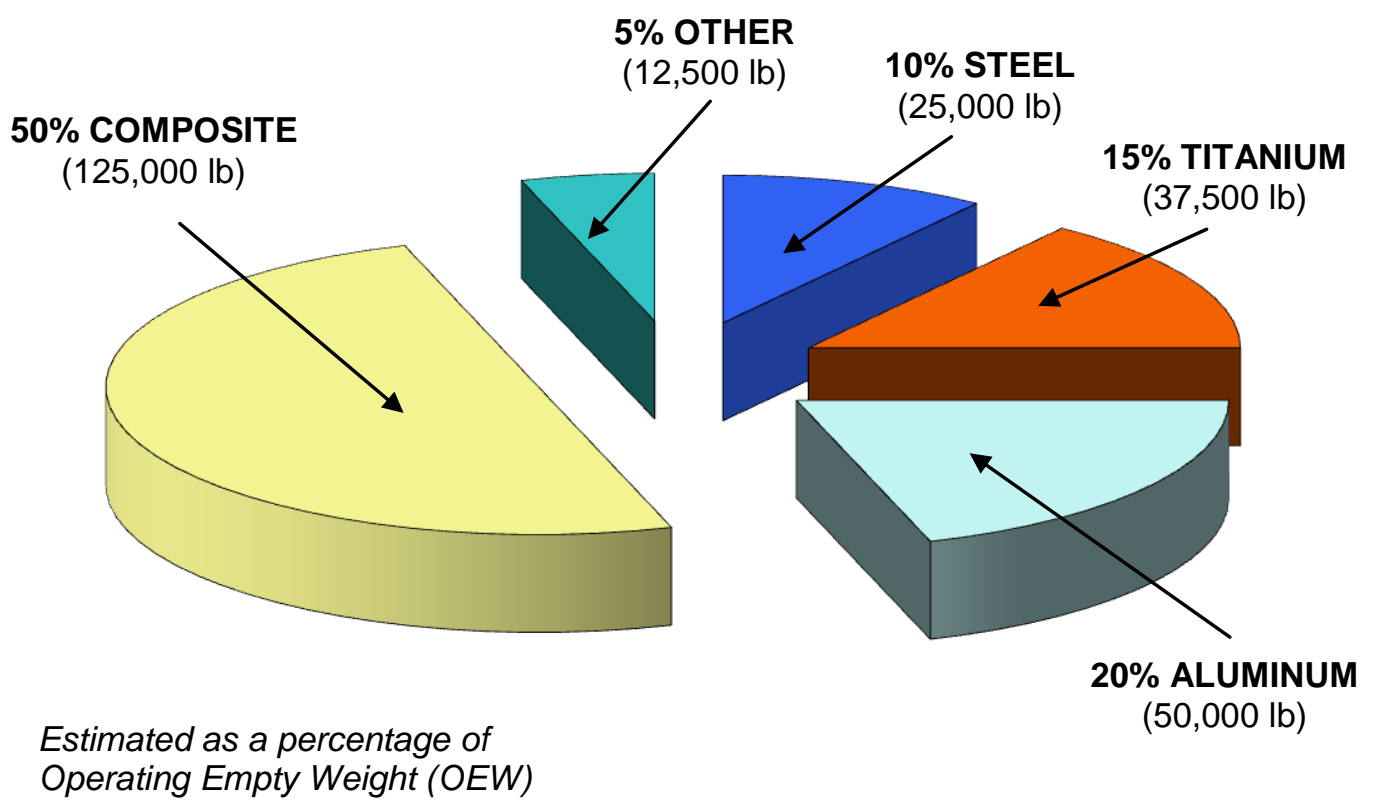

Figure 2. Material Distribution for the Boeing 787 Aircraft.

A new approach to manufacturing is needed that significantly reduces the amount of titanium consumed and the amount of work done to convert that titanium to finished products. A more efficient approach would yield significant reductions in energy consumption as well as manufacturing costs, and lead to a more sustainable aircraft industry. To this end, we proposed this project to develop a transformational approach to titanium component fabrication that utilizes emerging methods of titanium reduction technology which dramatically reduce energy consumption and material costs, and in turn enables the low-cost fabrication of titanium components. This final technical report presents the results of this project performed by Boeing Research \& Technology (BR\&T) and partner Oak Ridge National Laboratory (ORNL). In the following section, the current state of the art is discussed in more detail, and the project objectives and technical approach are presented. 


\section{BACKGROUND}

The Kroll process, which has been used to produce titanium metal commercially for the last half century, is an expensive energy-intensive high-temperature batch process. Titanium dioxide $\left(\mathrm{TiO}_{2}\right)$, mined from heavy mineral sand deposits, is first converted into $\mathrm{TiCl}_{4}$ via a carbochlorination process in which chlorine gas is passed over red-hot $\mathrm{TiO}_{2}$ in the presence of carbon:

$$
\mathrm{TiO}_{2}+2 \mathrm{Cl}_{2}+2 \mathrm{C} \rightarrow \mathrm{TiCl}_{4}+2 \mathrm{CO}
$$

The reaction product $\mathrm{TiCl}_{4}$ (titanium tetrachloride, often referred to as "tickle"), a clear liquid at room temperature, is then converted to titanium sponge by reduction with molten magnesium via the reaction:

$$
\mathrm{TiCl}_{4}+\mathrm{Mg} \rightarrow \mathrm{Ti}+2 \mathrm{MgCl}_{2}
$$

The process is capable of producing up to 10 tons of titanium metal per cycle. However, it requires that the contents of the reaction vessel be held at a temperature of $1472^{\circ} \mathrm{F}\left(800^{\circ} \mathrm{C}\right)$ for a cycle time of up to two weeks. The product of the reaction, termed titanium sponge due to its porous nature, is then ground up and pressed into a billet together with alloying elements which is then melted to produce an alloy ingot. That ingot is then used as the starting material to produce titanium alloy mill products. Titanium alloys are typically melted multiple times to ensure chemical uniformity and cleanliness. The melting process is also energy intensive, since the melting temperature of titanium is just over $3000^{\circ} \mathrm{F}\left(1648^{\circ} \mathrm{C}\right.$ ) and the ingots are large (from 3 to 7 tons). Vacuum arc melting, the standard approach, requires about 25 hours to melt an ingot, and the process is repeated two or three times. The alloy ingot is then worked by forging, rolling, or extrusion to produce conventional mill products which are then heat treated and machined to produce finished components. The long cycle time, multiple processing steps, and high temperatures required for each step in the conversion process all contribute to the high costs of conventional titanium mill products. The cost of titanium plate is illustrated in Figure 3 . The mineral is only $4 \%$ of the cost. Conversion from mineral to metallic titanium sponge represents about $34 \%$ of the cost, ingot melting to form the alloy is $15 \%$, and hot working of alloy ingot into finished mill product and final heat treatment represents $47 \%$ of the cost.

A number of emerging extraction processes are under development which could lead to a replacement for the Kroll approach. Several of these processes produce titanium powder or particulates as a product. The availability of low-cost titanium powders may in turn enable a more efficient approach to the manufacture of titanium components using existing commercial powder metallurgy (PM) processes. Powder metallurgical approaches to component fabrication have not been used to a great extent for titanium structural parts, due to the high cost of powder. Titanium powders produced by methods such as plasma rotating electrode (PREP) and gas atomization (GA) processes require multiple melting steps and typically cost around $\$ 150 / 1 b$. If these new reduction processes can produce titanium powder at significantly lower cost, the PM approach becomes a viable option for fabricating titanium products. The availability of low cost powders enables the fabrication of near net shape (NNS) products, in which powder is consolidated by the application of heat and pressure into a shape that is close to that of the desired finished component. The advantage of the NNS approach is that the amount of material 
required is minimized, the $\mathrm{B} / \mathrm{F}$ is significantly lowered, and thus the amount of machining required for component fabrication is greatly reduced. If the $\mathrm{B} / \mathrm{F}$ can be reduced from an average of 6 down to around 2, the amount of raw material required for part fabrication is cut by $80 \%$. Since machining typically represent $50 \%$ of the cost of a finished titanium component, the use of NNS preforms would result in a significant fabrication cost reduction. Thus, a breakthrough in the titanium extraction process enables a more efficient fabrication approach to achieve both energy efficiency and cost reductions. Two of the most promising innovative processes to primary titanium production currently in the commercialization stage are the Armstrong Process, being developed by International Titanium Powder (ITP), a subsidiary of Cristal Global, and the FFC Cambridge process being developed by Metalysis, Ltd.

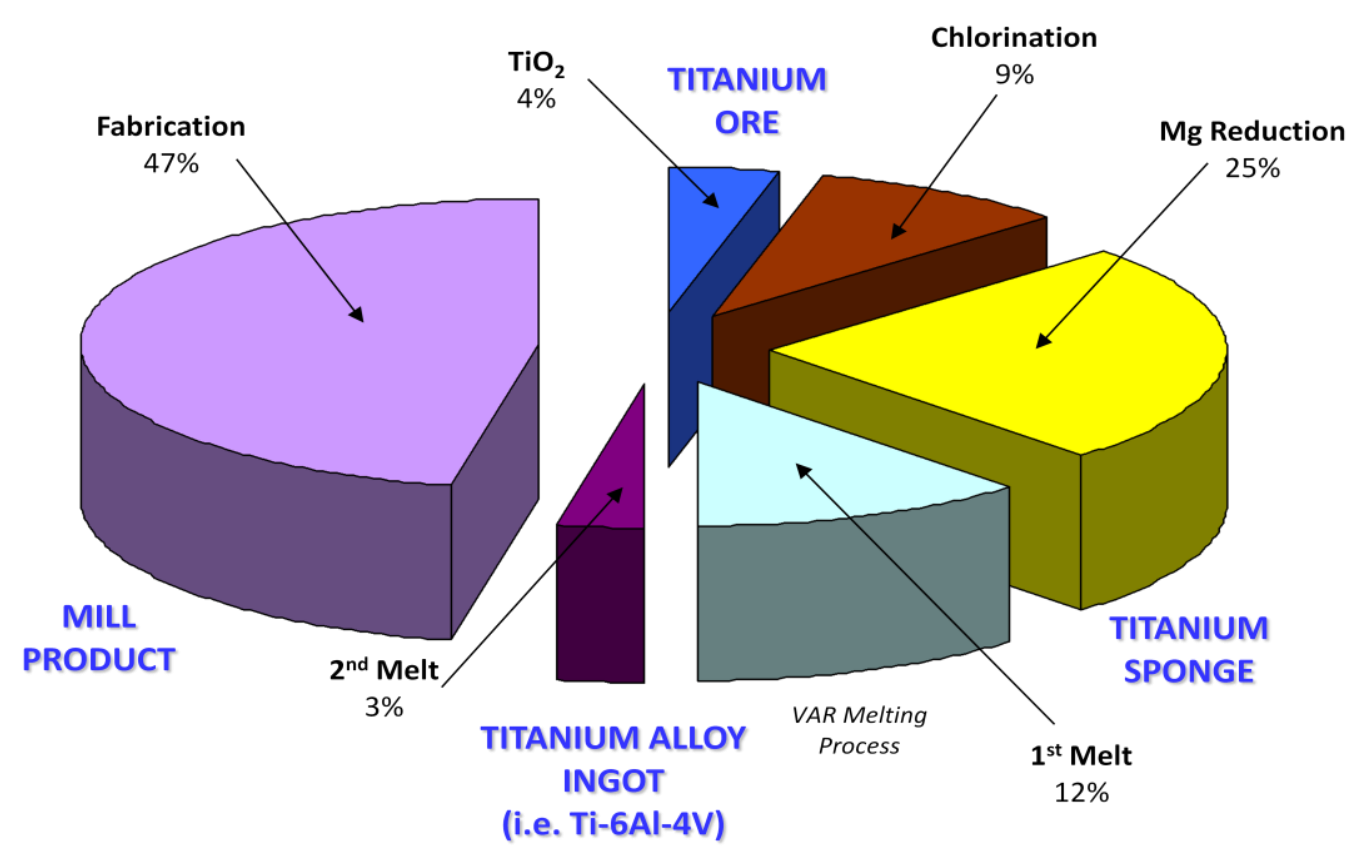

The cost of titanium mill products is roughly split between conversion from mineral to alloy ingot and hot working of ingot into finished mill product.

Figure 3. Cost of Conventional Titanium Mill Products

\section{The Armstrong Process}

In the Armstrong process, shown schematically in Figure 4, $\mathrm{TiCl}_{4}$ is injected as a superheated vapor into a flowing liquid sodium stream, where it is reduced to Ti and salt via the reaction:

$$
\mathrm{TiCl}_{4}+4 \mathrm{Na} \rightarrow \mathrm{Ti}+4 \mathrm{NaCl}
$$

The titanium reaction product forms in the sodium stream as a very fine solid state powder. The excess sodium is then vacuum-distilled away, leaving a cake of Ti powder and salt. This cake is then washed to remove the salt, and the Ti powder is dried. An example of the powder produced by the Armstrong process is show in Figure 5. The Armstrong process offers a number of 
advantages. First, it is a continuous process, and will produce titanium powder as long as liquid sodium flows through the reactor and $\mathrm{TiCl}_{4}$ vapor is injected into the sodium stream. In addition, it can produce titanium alloys directly as powder by injecting the proper stoichiometric mixture of metal halides into the sodium stream. The ability to produce alloy powder directly eliminates the need for the expensive ingot melting steps used to produce conventional alloy mill products. Finally, it is a relatively low-temperature process, operating at a temperature around $392^{\circ} \mathrm{F}$ $\left(200^{\circ} \mathrm{C}\right)$ instead of the $1472^{\circ} \mathrm{F}\left(800^{\circ} \mathrm{C}\right)$ required for the Kroll process, and thus requires significantly less energy. These benefits should result in a relatively low-cost powder product. International Titanium Powder (ITP), a unit of Cristal Global Limited, owns the rights to commercialize the Armstrong process. A pilot plant in Lockport, IL has the capacity to produce up to $500 \mathrm{lbs}$. of powder per batch run. A 4 million lb/year production facility has been constructed and is currently being brought online in Ottowa, IL.

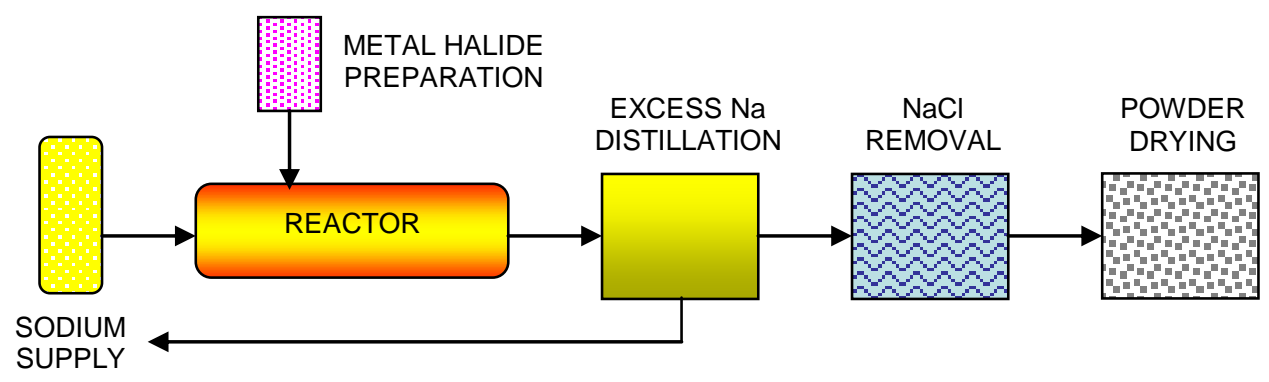

The Armstrong Process can produce alloy powders directly by reduction of the proper mixture of metal halides.

Figure 4. Schematic of the Armstrong Process

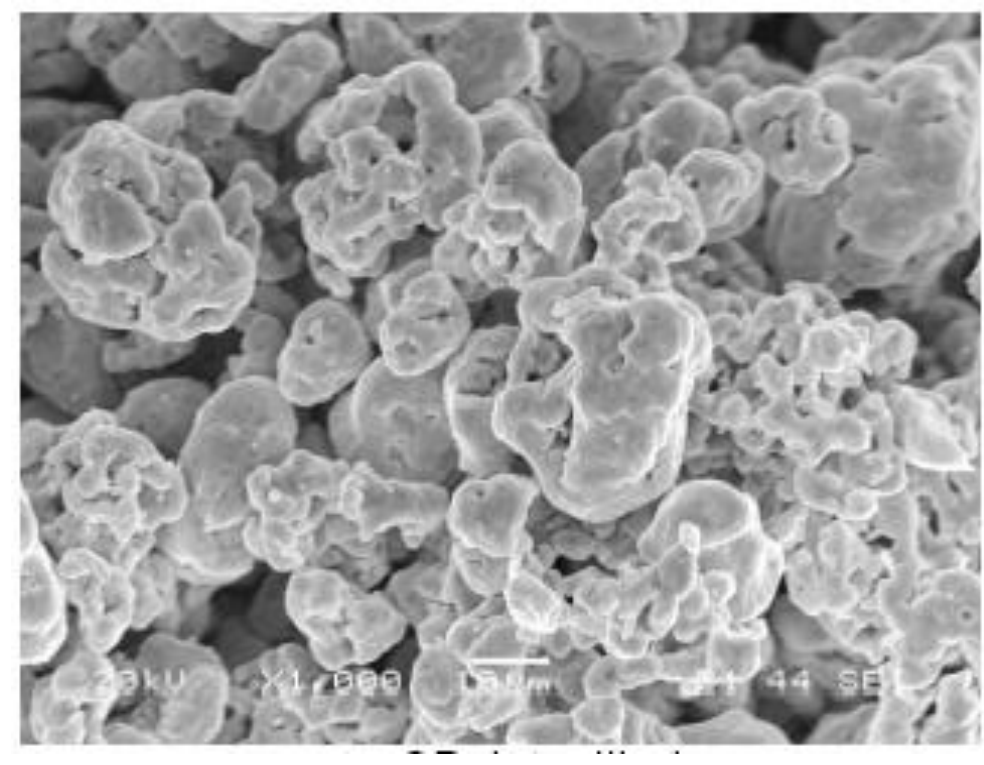

Figure 5. Titanium Powder Produced by the Armstrong Process (jet milled). 


\section{The Cambridge Process}

Another emerging conversion process is the FFC Cambridge process, shown schematically in Figure 6. The Cambridge process, under development by Metalysis Ltd, Rotherham, England, differs from the Armstrong process in that it produces titanium directly from $\mathrm{TiO}_{2}$, eliminating the intermediate high-temperature chlorination step to produce $\mathrm{TiCl}_{4}$. It is an electrolytic process in which a $\mathrm{TiO}_{2}$ electrode, produced by blending oxide powder with a binder and partially sintering, is reduced in molten $\mathrm{CaCl}_{2}$ electrolyte. The process also has the potential to produce titanium alloys directly by mixing metal oxides in the proper ratio to form the electrode. A variety of product forms can be produced, including discs or pellets. The reduced electrode can then be crushed, washed, and dried to produce a powder form.

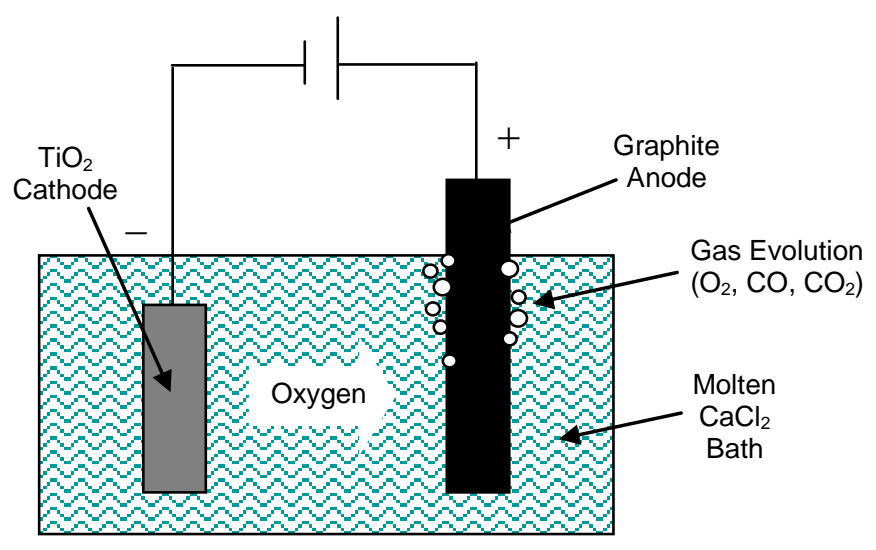

Figure 6. Schematic of the FFC Cambridge Process.

In a report prepared in 2002 for the Northwest Alliance for Transportation Technology, an alliance between Pacific Northwest National Laboratory (PNNL), auto manufacturers, research universities, and the DOE, cost models were developed for the Armstrong and Cambridge processes that could be used to understand the potential economic impact of each approach (Reference 1,2). A number of assumptions were made in the model, including costs for precursor materials such as sodium, $\mathrm{TiO}_{2}$ and $\mathrm{TiCl}_{4}$, energy and labor costs, and production output, which are detailed in their report. Costs per pound of product, broken into various categories, are summarized in Figure 7. This analysis indicated that both Armstrong and FFC Cambridge processes could produce titanium at a cost at least equivalent to conventional $\mathrm{Ti}$ sponge produced by the Kroll process. At the time of the study, the price of titanium sponge had ranged in price from between $\$ 3$ and $\$ 7 / \mathrm{lb}$ over the previous twenty years. However, the price of titanium almost doubled between 2003 and 2006, because increasing demand for titanium exceeded the available supply of scrap and sponge, as well as the capacity of the industry to produce new metal. A major factor in the increased demand was the large number of orders placed for commercial aircraft, and the increased amount of titanium needed to produce those aircraft. It is reasonable to assume that the price of materials produced by the Armstrong and Cambridge processes would also increase in value due to such market forces by a similar amount. However, regardless of market fluctuations in the price of titanium, it is reasonable to assume that the products of these emerging processes should have a price per pound comparable 
to that of conventional titanium sponge. For both processes, the majority of costs are associated with the fixed costs of the facility and raw material.

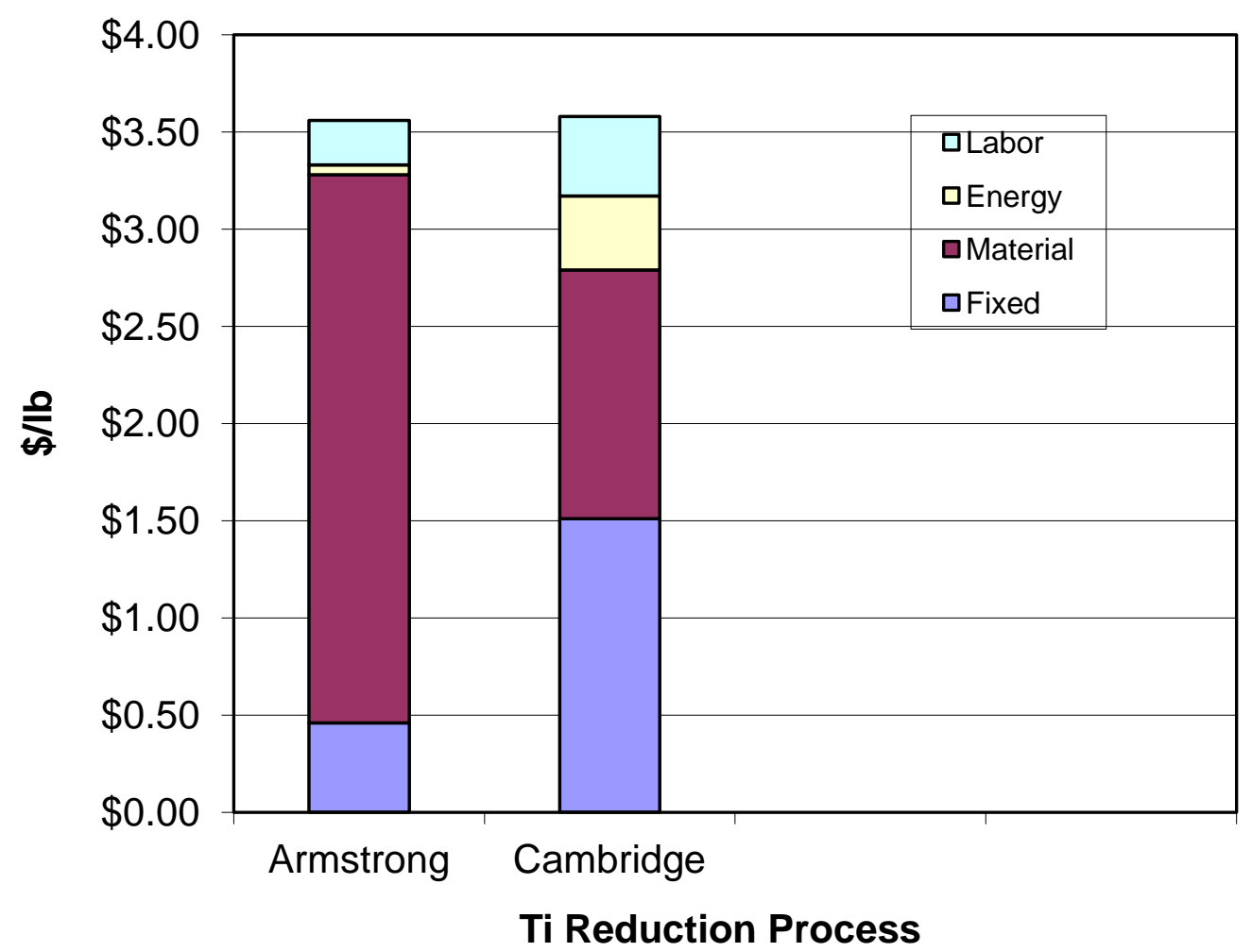

Figure 7. Cost Analysis for the Armstrong and Cambridge Processes.

Beyond developing the reduction processes themselves, the key technical challenge is to create an approach that transforms the low-cost powder produced by these processes into useful products in an efficient and affordable manner. Low-cost powders could be used as a sponge replacement for melting of alloy ingots. However, the primary advantage of these emerging processes is the ability to produce titanium alloys directly during the reduction process. This capability eliminates the need for the multiple ingot melting steps used in conventional processing to add the alloying elements and homogenize the material. Since the powder is prealloyed, it could be transformed into useful mill products directly via powder metallurgy processing to achieve significant cost reductions. Successful development of a manufacturing process that uses the powder in a powder metallurgy approach to fabricate finished titanium components would significantly reduce energy consumption while simultaneously lowering the cost of components. Using the powder as a sponge replacement negates one of the primary benefits of the process, namely that alloy powder can be produced directly without the need for any of the melting steps used to add the alloying elements in conventional materials. If successful, such a process would start with the mineral and end with a finished component without any material ever being melted. This solid state "meltless titanium" approach offers the 
potential for a significant reduction in the energy required for extraction together with cost reductions for finished components.

NNS machining preforms made from metal powders are not limited to as-consolidated shapes. And, many larger aircraft part geometries are not amenable to his approach due to the size limitations of consolidation equipment. In addition, the properties of as-consolidated powders are typically not as good as those for material that has been subjected to further hot working by forging, rolling, or extrusion. To address these issues, low-cost powders could also be used to produce affordable plate and extrusion products, and then machining preforms could be fabricated by assembling various simple geometric forms cut from these mill products into an overall shape as close as possible to the desired finished component. Welding processes such as electron beam and laser welding could be applied for some preform configurations. Solid state joining technologies currently being developed for titanium such as friction stir welding (FSW) and linear friction welding (LFW) could also be used to join the basic geometric forms together and create an efficient preform shape. This approach could be attractive for larger structural components such as airframe components, for which optimum mechanical properties are required for performance. An example of such a processing path to achieve a near net shaped machining preform from more conventional wrought products is illustrated schematically in Figure 8 .

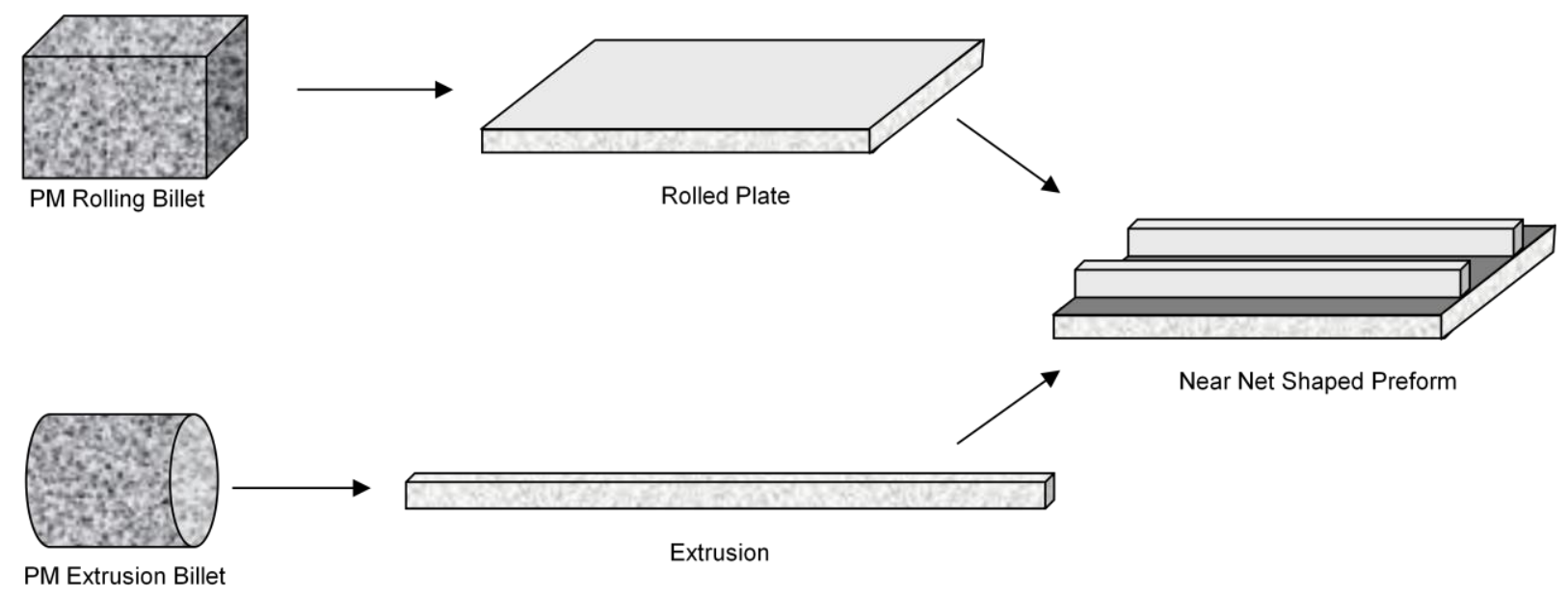

For large airframe structural components, new fabrication technologies such as friction stir welding and linear friction welding may be used to assemble efficient machining preforms.

Figure 8. Near Net Shaped Machining Preform Fabrication

In 2008, Boeing estimated the cost of various product forms produced from low-cost prealloyed powders. Using an estimate of $\$ 7 / \mathrm{lb}$ for Armstrong powder, which was considered a reasonable estimate at the time, plate product produced by hot isostatic pressing (HIP) followed by rolling was predicted to cost $\$ 13.20 / \mathrm{lb}$, including powder, consolidation, can and can removal, heat 
treatment, and inspection costs. This estimate assumes a conservative final yield of useful material of $80 \%$ after can removal and gaging to proper plate thickness. Given that current spot prices for conventional mill products can range up to $\$ 50 / \mathrm{lb}$, the savings potential of the solid state approach is obvious. Even if market prices of conventional mill products were to return to their pre-spike prices of 2002, these estimated costs represent a cost reduction of $50 \%$. Estimates for a number of product forms produced from Armstrong powders are summarized in Table 1.

\begin{tabular}{|c|c|c|c|c|}
\hline COST ELEMENT & $\begin{array}{l}\text { PLATE } \\
\text { Can+Roll }\end{array}$ & $\begin{array}{l}\text { BILLET } \\
\text { Can+HIP }\end{array}$ & $\begin{array}{c}\text { PLATE } \\
\text { Can+HIP+Roll }\end{array}$ & $\begin{array}{l}\text { FORGING } \\
\text { Can+HIP } \\
\text { +Forge }\end{array}$ \\
\hline Powder Type & Prealloyed & Prealloyed & Prealloyed & Prealloyed \\
\hline Product Form & 1" Plate & 8" Dia Billet & 1" Plate & 8" Dia Billet \\
\hline $\begin{array}{l}\text { Powder Type } \\
\text { CP Powder Cost (\$/lb) }\end{array}$ & $\begin{array}{c}\text { ITP } \\
4\end{array}$ & $\begin{array}{c}\text { ITP } \\
4\end{array}$ & $\begin{array}{c}\text { ITP } \\
4\end{array}$ & $\begin{array}{c}\text { ITP } \\
4\end{array}$ \\
\hline $\begin{array}{l}\text { Alloy Powder Cost }(\$ / l b) \\
\text { Blending } \\
\text { Blending Cost }(\$ / l b)\end{array}$ & $\begin{array}{c}7 \\
\text { pre-alloy } \\
0\end{array}$ & $\begin{array}{c}7 \\
\text { pre-alloy } \\
0\end{array}$ & $\begin{array}{c}7 \\
\text { pre-alloy } \\
0\end{array}$ & $\begin{array}{c}7 \\
\text { pre-alloy } \\
0\end{array}$ \\
\hline $\begin{array}{l}\text { Pre-Consolidation } \\
\text { Density } \\
\text { Pre-Con Cost }(\$ / l b)\end{array}$ & $\begin{array}{c}\text { attrit/press } \\
50 \% \\
0.3\end{array}$ & $\begin{array}{c}\text { attrit/press } \\
50 \% \\
0.3\end{array}$ & $\begin{array}{c}\text { attrit/press } \\
50 \% \\
0.3\end{array}$ & $\begin{array}{c}\text { attrit/press } \\
50 \% \\
0.3\end{array}$ \\
\hline $\begin{array}{l}\text { Encapsulation } \\
\text { Encap Can Cost (\$) } \\
\text { Max Encap Len (in) } \\
\text { Max Encap Wid (in) } \\
\text { Max Encap Tkns (in) } \\
\text { Encap Size (lb) }\end{array}$ & $\begin{array}{c}\text { Can } \\
1000 \\
144 \\
48 \\
8 \\
4479 \\
\end{array}$ & $\begin{array}{c}\text { Can } \\
1000 \\
96 \\
20 \\
20 \\
3110 \\
\end{array}$ & $\begin{array}{c}\text { Can } \\
1000 \\
96 \\
58 \\
8 \\
3608 \\
\end{array}$ & $\begin{array}{c}\text { Can } \\
1000 \\
96 \\
20 \\
20 \\
3110 \\
\end{array}$ \\
\hline $\begin{array}{l}\text { Consolidation } \\
\text { Consolid Cost }(\$ / l b)\end{array}$ & $\begin{array}{l}\text { Roll } \\
1.0\end{array}$ & $\begin{array}{l}\text { HIP } \\
1.0 \\
\end{array}$ & $\begin{array}{r}\text { HIP } \\
1.0 \\
\end{array}$ & $\begin{array}{l}\text { HIP } \\
1.0 \\
\end{array}$ \\
\hline $\begin{array}{l}\text { Thermal Treatment } \\
\text { Thermal Treat Cost }(\$ / \mathrm{lb})\end{array}$ & $\begin{array}{c}\text { none } \\
0\end{array}$ & $\begin{array}{c}\text { none } \\
0\end{array}$ & $\begin{array}{c}\text { none } \\
0\end{array}$ & $\begin{array}{c}\text { none } \\
0\end{array}$ \\
\hline $\begin{array}{l}\text { Final Consolidation } \\
\text { Final Consolid Cost }(\$ / \mathrm{lb})\end{array}$ & $\begin{array}{c}\text { none } \\
0\end{array}$ & $\begin{array}{c}\text { none } \\
0\end{array}$ & $\begin{array}{c}\text { none } \\
0\end{array}$ & $\begin{array}{c}\text { none } \\
0\end{array}$ \\
\hline $\begin{array}{l}\text { Gaging } \\
\text { Gaging Cost }(\$ / l b)\end{array}$ & $\begin{array}{l}\text { Roll } \\
0.8\end{array}$ & $\begin{array}{c}\text { none } \\
0.8\end{array}$ & $\begin{array}{l}\text { roll } \\
0.8\end{array}$ & $\begin{array}{c}\text { forge } \\
1.0\end{array}$ \\
\hline $\begin{array}{l}\text { Can Removal } \\
\text { Can Removal Cost }(\$)\end{array}$ & $\begin{array}{l}\text { mill } \\
972\end{array}$ & $\begin{array}{l}\text { turn } \\
500\end{array}$ & $\begin{array}{l}\text { mill } \\
792\end{array}$ & $\begin{array}{l}\text { turn } \\
500\end{array}$ \\
\hline $\begin{array}{l}\text { Heat Treat } \\
\text { Heat Treat Cost }(\$)\end{array}$ & $\begin{array}{c}\text { MA \& VCF } \\
0.3\end{array}$ & $\begin{array}{l}\text { MA } \\
0.3\end{array}$ & $\begin{array}{c}\text { MA \& VCF } \\
0.3\end{array}$ & $\begin{array}{l}\text { MA } \\
0.3\end{array}$ \\
\hline $\begin{array}{l}\text { NDT } \\
\text { NDT Cost }(\$ / l b)\end{array}$ & $\begin{array}{c}\text { Final UT } \\
0.20 \\
\end{array}$ & $\begin{array}{c}\text { Final UT } \\
0.20 \\
\end{array}$ & $\begin{array}{c}\text { Final UT } \\
0.20 \\
\end{array}$ & $\begin{array}{c}\text { Final UT } \\
0.20 \\
\end{array}$ \\
\hline Yield & 0.8 & 0.7 & 0.765 & 0.81 \\
\hline Final Wt. (lb) & 3583 & 2177 & 2760 & 2519 \\
\hline Final Cost $(\$)$ & 43,626 & 31,360 & 36,430 & 31,982 \\
\hline Final Cost (\$/lb) & $\$ 12.18$ & $\$ 14.40$ & $\$ 13.20$ & $\$ 12.70$ \\
\hline
\end{tabular}

Table 1. Estimated Costs of Various Solid State Mill Products Produced from Armstrong Powders. 


\section{Project Objectives}

The project had four main objectives. First, we conducted a survey of titanium airframe parts and part geometries to define the major part types or families and their requirements in terms of overall size and shape. From the results of this survey, we can identify those part types for which the near net shaped approach would have the greatest impact in terms of material and cost reduction.

Our second objective was to define manufacturing strategies for each part type that transform low-cost powders into finished components in the most efficient way. These strategies include powder consolidation, production of intermediate geometric forms, and joining/assembly techniques to produce the optimum NNS preform design. By analyzing energy consumption and costs for each approach and quantifying the benefits, we could identify the most promising strategies.

Our third objective was to perform select experiments with small quantities of low-cost powder or particulates to evaluate the technical feasibility of the various approaches for conversion of powder into NNS machining preforms. Based on the results of these analyses and experiments, our final objective was to define the most technically feasible approaches to component fabrication using low-cost powders and NNS preforms, and establish a project continuation plan to fully development and transition NNS titanium technology to industry.

As the major domestic consumer of titanium, Boeing has active research programs in a variety of technologies directly applicable to the proposed project, the necessary expertise in the metallurgy and processing of titanium, and the experience necessary to develop and transition new technology into production. The project was led by the Advanced Metallics Fabrication group of Boeing Research \& Technology, the advanced research and development organization of The Boeing Company. Oak Ridge National Laboratory (ORNL) was the co-investigator. Boeing and ORNL have worked together for several years to examine various issues related to efficient titanium powder metallurgy processing, including powder characteristics, consolidation, and secondary processing such as plate rolling and heat treatment. This experience was leveraged for the performance of this project.

\section{RESULTS AND DISCUSSION}

The project was organized into six tasks: (1) Assess the Benefits, (2) Identify Opportunities, (3) Evaluate Approaches to Near Net Shape Products, (4) Determine Technical Feasibility, (5) Define a Viable Process, and (6) Manage the Program. Results and discussion for technical tasks 1 through 5 are presented in the following sections.

\section{Task 1: Assess the Benefits}

The objective of this task is to estimate the potential energy and economic benefits of NNS titanium technology using low-cost titanium alloy powders as the starting material. The cost study is a critical element of the benefits analysis, since it would be difficult to realize energy 
benefits that increase manufacturing costs in a business environment where a primary goal is to reduce costs for global competitiveness. Our goal is to define the "benefits space" where a strong economic incentive drives implementation of energy efficient manufacturing approaches.

\section{Energy Benefits}

The energy benefits analysis performed in this task is summarized in Table 2. In performing the analysis, a number of assumptions were made to establish boundary conditions. First, the analysis is based on the availability of low-cost titanium alloy powder produced via the Armstrong process by International Titanium Powder (ITP), since this is the most mature of the emerging processes and a production plant is currently under construction. We have used the production capacity of the new ITP plant of 4 million pounds per year, and projected a growth profile for plant expansion and powder production to 6 million pounds per year in 2020. NNS performs could be fabricated using conventional mill products as the building blocks to achieve cost reductions, but we believe the Armstrong alternative to the Kroll process is needed to achieve significant energy savings.

We have based the impact of titanium NNS technology on the production rates for the Boeing 787 aircraft, which is driving the domestic demand for titanium products in commercial aircraft. The inclusion of additional aircraft in the future may result in increased benefits. While Boeing legacy aircraft such as the 757,767 , and 747 also incorporate titanium components, the amount of titanium required is much less than for the 787 , and so the 787 dominates the analysis of future benefits. Focusing the analysis on the 787 provides us with a conservative estimate of the benefits. We assumed that each 787 airframe (excluding engines) requires approximately $116,000 \mathrm{lbs}$ of titanium mill products which yield roughly 19,000 lbs of finished machined parts. While machining chips are recycled for melting into new alloy ingot, we have not included recycling in the energy analysis due to the fact that only a small fraction of most fresh ingot is comprised of recycled material. We also assumed that using the near-net approach, the typical $\mathrm{B} / \mathrm{F}$ ratio, which is the ratio of the amount of mill stock used to the weight of the finished part, can be reduced from the average 6:1 down to 2:1.

We assumed a conversion energy (to convert mineral to metal) of $165 \mathrm{MBtu} /$ ton for Armstrong powder, compared to $355 \mathrm{MBtu} /$ ton for conventional titanium produced via the Kroll process (Reference 3). This conversion energy contributes by far the greatest amount to the overall process of converting $\mathrm{TiO}_{2}$ into useful titanium products. However, we have included estimates for each step in processing, including conversion, ingot melting, hot working into mill product, powder consolidation, and heat treatment, in the analysis. For estimating energy consumed in each processing step, we used the following estimates for the energy requirements for conventional titanium: $355 \mathrm{MBtu} /$ ton for conversion from mineral to metal via the Kroll process, 6.14 MBtu/ton for ingot melting (assumes triple melting for aerospace grade material), 13.27 MBtu/ton for primary fabrication (hot rolling), 2.3 MBtu/ton for heat treatment, and 3.54 MBtu/ton for machining. Using Armstrong alloy powders, the energy required for alloying through multiple ingot melting steps is eliminated, and primary fabrication includes the energy required for consolidation of powder into billet by hot pressing. We also assumed a material yield loss of $40 \%$ in converting titanium sponge into mill products. In determining overall 
energy savings, we assumed the energy required for joining to build a machining preform is negligibly small compared to that consumed by the material processing steps.

The amount of conventional titanium mill stock required for the given 787 production rate is based on the results of the survey performed in Task 2: Identify Opportunities (see Figure 12). This survey indicated that plate stock accounts for $59.9 \%$ of the titanium used by weight, extrusion $16.7 \%$, bar stock $5.9 \%$, and forgings $15.9 \%$. Together these products account for over $98 \%$ of the titanium used in the 787 airframe. The balance of titanium used is in the form of sheet and hydraulic tubing. While there may be a large number of sheet metal and tubing parts, they contribute only a small fraction to the total weight of the aircraft. In the absence of NNS technology, the amount of conventional titanium (all product forms) required for 787 production rises from 16.5 million pounds in 2010 to 24.8 million pounds in 2020 at currently projected build rates.

The benefits analysis also assumes a technology penetration profile. Several years will be required to fully qualify NNS preforms for service. A commercial supplier of powder must be available to provide a quantity of material sufficient to establish statistically-based design allowables (physical and mechanical properties obtained by testing multiple powder heats, multiple product lots, etc.). In addition, standard material and processing specifications are required for procurement of preforms. Also, given a standard preform, time and resources are required to qualify individual components for service. This component qualification process typically utilizes a building block approach, beginning with coupon testing followed by structural tests on subscale structural elements and finally prototype components, which also requires time and resources. We are investigating approaches to rapid qualification that will reduce the time and resources required for part qualification without compromising the statistically based confidence in product performance that is required. We assumed initial technology transition to production in 2015 with $5 \%$ of titanium parts transitioning to NNS machining preforms, and a growth in penetration of from 5 to $10 \%$ per year to a peak of $50 \%$ in the year 2020. This penetration profile assumes a strong economic benefit to drive the transition. The analysis indicates by the year 2020 , with $50 \%$ of titanium airframe components utilizing NNS technology, 8.29 million pounds of titanium will be removed from the manufacturing cycle for the year, a reduction of $33 \%$ compared to the current state using conventional mill products. Using current manufacturing strategy, 24.87 million pounds of titanium mill products will be required to satisfy the production rate in 2020. Reducing the B/F from 6 to 2 with NNS technology eliminates 12.44 million pounds of conventional mill products, replacing them with 4.15 million pounds of NNS machining performs, for a net reduction of 8.29 million pounds of titanium. For the period from 2015 to 2020, titanium usage will have been reduced by 25.56 million pounds. Energy consumption required to produce titanium products will have decreased from 7.68 TBtu per year for conventional mill products to 5.55 TBtu per year for NNS machining performs, a reduction of 2.13 TBtu per year or $28 \%$. These values for titanium raw material reduction and energy savings will vary from part to part, depending on the $\mathrm{B} / \mathrm{F}$ for a particular geometry.

The recycling of machining chips and other scrap metal will have some effect on the energy required to produce titanium products. Many titanium producers do not divulge the fraction of recycled material used in the melting of fresh alloy ingots. For the sake of discussion, the impact 
of recycling on energy is estimated for the case where $10 \%$ of the furnace charge is recycled metal. The scrap reduces the amount of fresh titanium sponge used in melting, and thus the amount of energy consumed by the Kroll process to produce that sponge, by $10 \%$. The impact of using recycled material on the energy required for ingot melting is unchanged, since the same amount of metal is melted regardless of whether it is fresh sponge or recycled material. The impact on the total energy required to produce the amount of conventional titanium required in Table 2 is a reduction of $9.6 \%$. Every additional $1 \%$ of recycled furnace charge equates to an additional reduction in energy of $0.96 \%$.

\section{Economic Benefits}

A cost analysis was performed to quantify the economic benefits of NNS manufacturing and establish target costs for NNS performs. Again, our goal is to reduce the B/F ratio from an average of 6 for titanium machined parts to a value of 2 through the use of NNS machining preforms. Estimated machining costs are summarized in Figure 9 for varying component weights as a function of the $\mathrm{B} / \mathrm{F}$ ratio. To illustrate the impact of varying $\mathrm{B} / \mathrm{F}$ for specific part geometries, we have examined $\mathrm{B} / \mathrm{F}$ values of 10,5 , and 2 . The average $\mathrm{B} / \mathrm{F}$ for the 787 is around 6 , and the goal of the NNS approach is to reduce this value to 2. The range from 5 to 10 may be considered a "working region" for modern titanium components. Typical machined components used in the aircraft fuselage frame may weigh between 10 and 200 pounds, while heavier landing gear components can weigh up to $800 \mathrm{lbs}$, so the analysis covers a wide range of finished component weights from 10 to 1,000 pounds.

The machining costs are estimated based on state-of-the art cutting techniques for titanium, assuming that $97 \%$ of the machining is performed as a roughing operation providing for rapid metal removal, and 3\% is accomplished as a detailed finishing operation. We have estimated the cost of rough machining at $\$ 9.37$ per pound of metal removed, and finishing at $\$ 5.87$ per pound of metal removed based on current machining tools and methods. From Table 3, the machining cost reduction relative to a conventional $\mathrm{B} / \mathrm{F}$ of 10 is $56 \%$ at a $\mathrm{B} / \mathrm{F}$ of 5 and $89 \%$ for a $\mathrm{B} / \mathrm{F}$ of 2 . For a conventional $\mathrm{B} / \mathrm{F}$ of 5 , the machining cost reduction is $75 \%$ if the $\mathrm{B} / \mathrm{F}$ can be reduced to 2 .

Because of the reduced $\mathrm{B} / \mathrm{F}$ ratio, a reduction in raw material cost is realized in addition to the cost savings for reduced machining. Table 4 summarizes finished part costs (combined raw material plus machining costs) for the different $\mathrm{B} / \mathrm{F}$ ratios as a function of finished part weight. These dollar values are based on a baseline titanium mill product cost of $\$ 18.00$ per pound. We have used the cost of conventional mill product in this analysis, since powder-based mill product would have to be cost-competitive with conventional materials. If powder products are more expensive, then conventional materials would be used to fabricate the preforms due to the lower cost offered. Cost would drive the decision, rather than any energy considerations. Table 5 illustrates that changes in the price of titanium actually have little influence on the cost savings possible through implementation of NNS technologies, since the cost reduction is dominated by the large reduction in material and machining required for part fabrication. Even a doubling of the price of titanium from $\$ 18.00$ to $\$ 36.00$ per pound results in a difference in cost reduction of less than one percent, regardless of the original $\mathrm{B} / \mathrm{F}$ ratio. 
Table 2. Energy Savings Analysis for NNS Titanium

\begin{tabular}{|c|c|c|c|c|c|c|c|c|c|c|c|c|}
\hline & \multicolumn{12}{|c|}{ PRODUCTION YEAR } \\
\hline & 2010 & 2011 & 2012 & 2013 & 2014 & 2015 & 2016 & 2017 & 2018 & 2019 & 2020 & TOTAL \\
\hline & \multicolumn{12}{|c|}{ PREDICTED BENEFIT: ENERGY SAVINGS } \\
\hline ITP Production Rate, Ib/yr & 0 & $4,000,000$ & $4,000,000$ & $4,000,000$ & $4,000,000$ & $4,000,000$ & $6,000,000$ & $6,000,000$ & $6,000,000$ & $6,000,000$ & $6,000,000$ & \\
\hline 787 Build Rate, $\mathrm{A} / \mathrm{C} / \mathrm{mo}$ & 12 & 12 & 15 & 15 & 15 & 15 & 18 & 18 & 18 & 18 & 18 & \\
\hline Conventional Titanium Plate, Ib/yr & $10,098,144$ & $10,098,144$ & $12,622,680$ & $12,622,680$ & $12,622,680$ & $12,622,680$ & $15,147,216$ & $15,147,216$ & $15,147,216$ & $15,147,216$ & $15,147,216$ & $146,423,088$ \\
\hline Conventional Titanium Bar Product, Ib/yr & 991,152 & 991,152 & $1,238,940$ & $1,238,940$ & $1,238,940$ & $1,238,940$ & $1,486,728$ & $1,486,728$ & $1,486,728$ & $1,486,728$ & $1,486,728$ & $14,371,704$ \\
\hline Conventional Titanium Extrusion Product, It/yr & $2,819,520$ & $2,819,520$ & $3,524,400$ & $3,524,400$ & $3,524,400$ & $3,524,400$ & $4,229,280$ & $4,229,280$ & $4,229,280$ & $4,229,280$ & $4,229,280$ & $40,883,040$ \\
\hline Conventional Titanium Forged Product, Ib/yr & $2,671,200$ & $2,671,200$ & $3,339,000$ & $3,339,000$ & $3,339,000$ & $3,339,000$ & $4,006,800$ & $4,006,800$ & $4,006,800$ & $4,006,800$ & $4,006,800$ & $38,732,400$ \\
\hline Total Conventional Titanium, Ib/yr & $16,580,016$ & $16,580,016$ & $20,725,020$ & $20,725,020$ & $20,725,020$ & $20,725,020$ & $24,870,024$ & $24,870,024$ & $24,870,024$ & $24,870,024$ & $24,870,024$ & $240,410,232$ \\
\hline TiSponge Required @60\% Yield, Ib/yr & $27,633,360$ & $27,633,360$ & $34,541,700$ & $34,541,700$ & $34,541,700$ & $34,541,700$ & $41,450,040$ & $41,450,040$ & $41,450,040$ & $41,450,040$ & $41,450,040$ & $400,683,720$ \\
\hline Energy to Produce Sponge Required, MBtu & $4,904,921$ & $4,904,921$ & $6,131,152$ & $6,131,152$ & $6,131,152$ & $6,131,152$ & $7,357,382$ & $7,357,382$ & $7,357,382$ & $7,357,382$ & $7,357,382$ & $71,121,360$ \\
\hline Alloying Energy ( $3 \times$ Melt) Sponge to Ingot, MBtu & 84,862 & 84,862 & 106,078 & 106,078 & 106,078 & 106,078 & 127,293 & 127,293 & 127,293 & 127,293 & 127,293 & $1,230,500$ \\
\hline F abrication Energy, Ingot to Plate, MBtu/yr & 67,001 & 67,001 & 83,751 & 83.751 & 83,751 & 83.751 & 100,502 & 100,502 & 100,502 & 100,502 & 100,502 & 971,517 \\
\hline Fabrication Energy, Ingot to Bar, MEtu/yr & 6,576 & 6,576 & 8.220 & 8.220 & 8,220 & 8.220 & 9,864 & 9,864 & 9,864 & 9,864 & 9.864 & 95,356 \\
\hline F abrication Energy, Ingot to Extrusion, MEtu/yr & 18,708 & 18,708 & 23,384 & 23,384 & 23,384 & 23,384 & 28,061 & 28,061 & 28,061 & 28,061 & 28,061 & 271,259 \\
\hline Fabrication Energy, Ingot to Forging, MBtu/yr & 17,723 & 17,723 & 22,154 & 22,154 & 22,154 & 22,154 & 26,585 & 26,585 & 26,585 & 26,585 & 26,585 & 256,989 \\
\hline Heat Treatment Energy. MBtu/yr & 19,067 & 19,067 & 23,834 & 23,834 & 23,834 & 23,834 & 28,601 & 28,601 & 28,601 & 28,601 & 28,601 & 276,472 \\
\hline Total Conventional Energy, MBtu/yr & $5,118,859$ & $5,118,859$ & $6,398,574$ & $6,398,574$ & $6,398,574$ & $6,398,574$ & $7,678,288$ & $7,678,288$ & $7,678,288$ & $7,678,288$ & $7,678,288$ & $74,223,454$ \\
\hline NNS Penetration (fraction of parts converted) & 0.00 & 0.00 & 0.00 & 0.00 & 0.00 & 0.05 & 0.10 & 0.20 & 0.30 & 0.40 & 0.50 & \\
\hline Conventional Titanium Removed, Ib/yr & 0 & 0 & 0 & 0 & 0 & $1,036,251$ & $2,487,002$ & $4,974,005$ & $7,461,007$ & $9,948,010$ & $12,435,012$ & $38,341,287$ \\
\hline NearNet Ti Added, Ib/yr $\mathrm{B} / \mathrm{F}=6$ & 0 & 0 & 0 & 0 & 0 & 345,417 & 829,001 & $1,658,002$ & $2,487,002$ & $3,316,003$ & $4,145,004$ & $12,780,429$ \\
\hline Net Reduction in Titanium Stock, lbs $B / F=6$ & 0 & 0 & 0 & 0 & 0 & 690,834 & $1,658,002$ & $3,316,003$ & $4,974,005$ & $6,632,006$ & $8,290,008$ & $25,560,858$ \\
\hline WConventional Ti Removed, $\$ / y r$ B/F=6 & 0 & 0 & 0 & 0 & 0 & 3 & 7 & 13 & 20 & 27 & 33 & \\
\hline Conv. Ti Energy Avoided, MEtu/yr $\mathrm{B} / \mathrm{F}=6$ & 0 & 0 & 0 & 0 & 0 & 213,286 & 511,886 & $1,023,772$ & $1,535,658$ & $2,047,544$ & $2,559,429$ & $7,891,574$ \\
\hline NearNet Energy Added (Powder), MBtu/yr $B / F=6$ & 0 & 0 & 0 & 0 & 0 & 28.497 & 68,393 & 136,785 & 205,178 & 273,570 & 341,963 & \\
\hline NearNet Energy Added(Consolidation), MBtuhyr & 0 & 0 & 0 & 0 & 0 & 4,318 & 10,363 & 20,725 & 31,088 & 41,450 & 51,813 & \\
\hline NearNet Energy Added (F abrication), MBtu/yr & 0 & 0 & 0 & 0 & 0 & 2,292 & 5,500 & 11,001 & 16,501 & 22,002 & 27,502 & \\
\hline NearNet Energy Added (Joining), MEtu/yr & 0 & 0 & 0 & 0 & 0 & 250 & 300 & 300 & 300 & 300 & 300 & \\
\hline NearNet Energy Added (Heat Treat), MBtu/yr & 0 & 0 & 0 & 0 & 0 & 397 & 953 & 1,907 & 2,860 & 3.813 & 4,767 & \\
\hline Total Ne arNet Energy, MEtuhyr & 0 & 0 & 0 & 0 & 0 & 35.754 & 85,509 & 170,718 & 255,927 & 341,135 & 426,344 & \\
\hline Net Energy Savings, Preform, MEtu/yr $B / F=6$ & 0 & 0 & 0 & 0 & 0 & 177,532 & 426,377 & 853,054 & $1,279.731$ & $1,706,408$ & $2,133,085$ & $6,576,188$ \\
\hline
\end{tabular}




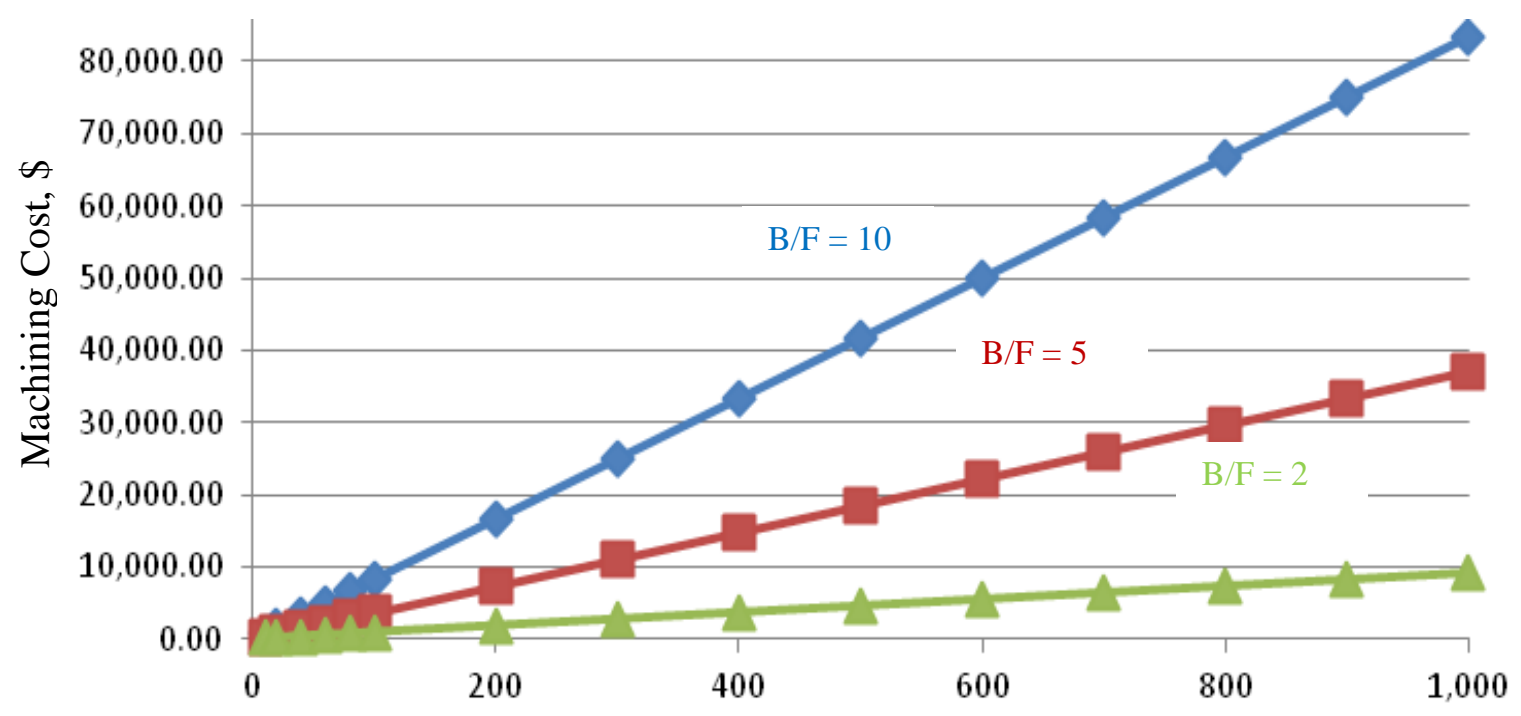

Finished Component Weight, lbs

Figure 9. Estimated machining costs as a function of finished part weight for three different buy-to-fly $(\mathrm{B} / \mathrm{F})$ ratios.

Table 4. Finished Part Material + Machining Costs as a $\mathrm{f}(\mathrm{B} / \mathrm{F})$ Ratio, $\$$

\begin{tabular}{cccc}
\hline Part Wt, lbs & \multicolumn{1}{c}{ B/F } & 2 \\
10 & 10 & 5 & 452.70 \\
20 & $2,634.29$ & $1,270.79$ & 905.40 \\
40 & $5,268.57$ & $2,541.59$ & $1,810.79$ \\
60 & $10,537.15$ & $5,083.18$ & $2,716.19$ \\
80 & $15,805.72$ & $7,624.76$ & $3,621.59$ \\
100 & $21,074.29$ & $10,166.35$ & $4,526.99$ \\
200 & $26,342.87$ & $12,707.94$ & $9,053.97$ \\
300 & $52,685.73$ & $25,415.88$ & $13,580.96$ \\
400 & $79,028.60$ & $38,123.82$ & $18,107.94$ \\
500 & $105,371.46$ & $50,831.76$ & $22,634.93$ \\
600 & $131,714.33$ & $63,539.70$ & $27,161.91$ \\
700 & $158,057.19$ & $76,247.64$ & $31,688.90$ \\
800 & $184,400.06$ & $88,955.58$ & $36,215.88$ \\
900 & $210,742.92$ & $101,663.52$ & $40,742.87$ \\
1,000 & $237,085.79$ & $114,371.46$ & $45,269.85$ \\
\hline
\end{tabular}




\begin{tabular}{ccccc}
\hline \multicolumn{4}{c}{ Table 5. Effect of Material Price on Cost Savings } \\
& Material + Machining Percent Cost Reduction from B/F of 10 to 2) & \\
\hline & 18.00 & Titanium Raw Material Price, \$/lb & 36.00 \\
$\begin{array}{c}\text { \% Cost Savings } \\
\text { B/F = 5>2 }\end{array}$ & 64.38 & 25.00 & 63.00 & 62.56 \\
$\% \begin{array}{c}\text { Cost Savings } \\
\text { B/F 10>2 }\end{array}$ & 82.82 & 82.22 & 81.93 & 81.67 \\
\hline
\end{tabular}

We have estimated NNS machining preform costs and the finished part cost savings achievable at those preform costs for a variety of scenarios. Material and machining cost savings achieved by reducing $\mathrm{B} / \mathrm{F}$ are partially offset by the cost of fabricating the preform, which reduce the total savings achievable. We have estimated preform costs and part savings for the case where from $30 \%$ to $70 \%$ of the material and machining savings are expended on preform fabrication. Results are summarized in Tables $6 \mathrm{~A}$ and $6 \mathrm{~B}$ through $10 \mathrm{~A}$ and $10 \mathrm{~B}$ for a reduction in $\mathrm{B} / \mathrm{F}$ from 5 to 2 , and in Tables $11 \mathrm{~A}$ and $11 \mathrm{~B}$ through $15 \mathrm{~A}$ and $15 \mathrm{~B}$ for a $\mathrm{B} / \mathrm{F}$ reduction from 10 to 2 . Target preform costs as a function of part weight are presented in tables $6 \mathrm{~A}$ through $15 \mathrm{~A}$, and finished part costs and cost savings are shown in Tables 6B through $15 \mathrm{~B}$ as a function of part weight. While the preform cost depends on the part weight, the cost per pound is independent of actual part weight for a given preform cost scenario. For example, using a NNS preform to reduce the $\mathrm{B} / \mathrm{F}$ from 5 to 2 , with $30 \%$ of the material and machining savings consumed for preform fabrication, a preform cost of $\$ 30.27 / \mathrm{lb}$ is determined (Table 6A). From Table 6B, this preform cost results in a finished part cost reduction of just over $45 \%$ and a reduction in the amount of titanium required for part fabrication of $60 \%$. Astual preform costs as a function of part weight are also given in Table 6A, and finished part costs as a function of part weight are presented in Table 6B. Similar estimates are found in Tables 7A and B through 15A and B for the other cost scenarios. 


\begin{tabular}{|c|c|c|c|c|c|c|}
\hline \multicolumn{7}{|c|}{$\begin{array}{l}\text { Table 6A. Near Net Shape Machining Preform Cost, B/F from } 5 \text { to } 2 \\
\text { 30\% of Material + Machining Cost Savings Applied to Preform Fabrication }\end{array}$} \\
\hline $\begin{array}{l}\text { Finished } \\
\text { Part } \\
\text { Weight, lb }\end{array}$ & $\begin{array}{l}\text { Savings } 5>2 \\
\text { B/F ratio }\end{array}$ & $\begin{array}{l}\text { Preform } \\
\text { Fabrication } \\
\quad @ 30 \%\end{array}$ & $\begin{array}{l}\text { Preform } \\
\text { Fabrication } \\
\quad \$ / l b\end{array}$ & $\begin{array}{c}\text { Preform } \\
\text { Material Cost, } \\
\$\end{array}$ & $\begin{array}{c}\text { Preform Cost } \\
\$\end{array}$ & $\begin{array}{l}\text { Preform } \\
\text { Cost } \$ / \mathrm{lb}\end{array}$ \\
\hline 10 & 818.10 & 245.43 & 30.27 & 360.00 & 605.43 & 30.27 \\
\hline 20 & 1636.19 & 490.86 & 30.27 & 720.00 & 1210.86 & 30.27 \\
\hline 40 & 3272.38 & 981.71 & 30.27 & 1440.00 & 2421.71 & 30.27 \\
\hline 60 & 4908.57 & 1472.57 & 30.27 & 2160.00 & 3632.57 & 30.27 \\
\hline 80 & 6544.76 & 1963.43 & 30.27 & 2880.00 & 4843.43 & 30.27 \\
\hline 100 & 8180.96 & 2454.29 & 30.27 & 3600.00 & 6054.29 & 30.27 \\
\hline 200 & 16361.91 & 4908.57 & 30.27 & 7200.00 & 12108.57 & 30.27 \\
\hline 300 & 24542.87 & 7362.86 & 30.27 & 10800.00 & 18162.86 & 30.27 \\
\hline 400 & 32723.82 & 9817.15 & 30.27 & 14400.00 & 24217.15 & 30.27 \\
\hline 500 & 40904.78 & 12271.43 & 30.27 & 18000.00 & 30271.43 & 30.27 \\
\hline 600 & 49085.73 & 14725.72 & 30.27 & 21600.00 & 36325.72 & 30.27 \\
\hline 700 & 57266.69 & 17180.01 & 30.27 & 25200.00 & 42380.01 & 30.27 \\
\hline 800 & 65447.64 & 19634.29 & 30.27 & 28800.00 & 48434.29 & 30.27 \\
\hline 900 & 73628.60 & 22088.58 & 30.27 & 32400.00 & 54488.58 & 30.27 \\
\hline 1000 & 81809.55 & 24542.87 & 30.27 & 36000.00 & 60542.86 & 30.27 \\
\hline
\end{tabular}

\begin{tabular}{|c|c|c|c|c|c|c|c|c|}
\hline \multicolumn{9}{|c|}{$\begin{array}{l}\text { Table 6B. Finished Part Cost and Raw Material Reductions, B/F from } 5 \text { to } 2 \\
30 \% \text { of Material + Machining Cost Savings Applied to Preform Fabrication }\end{array}$} \\
\hline $\begin{array}{c}\text { Finished } \\
\text { Part } \\
\text { Weight, } \\
\text { lb }\end{array}$ & $\begin{array}{c}\text { Preform } \\
\text { Cost, } \$\end{array}$ & $\begin{array}{l}\text { Preform } \\
\text { Machining } \\
\text { Cost, } \$\end{array}$ & $\begin{array}{l}\text { Finished } \\
\text { Part Cost, } \\
\quad \$\end{array}$ & $\begin{array}{c}\text { Cost } \\
\text { per Part } \\
\text { Lb, } \$\end{array}$ & $\begin{array}{c}\text { Cost } \\
\text { Savings, } \$\end{array}$ & $\begin{array}{c}\text { Cost } \\
\text { Savings, } \\
\%\end{array}$ & $\begin{array}{l}\text { Titanium } \\
\text { Reduction, } \\
\quad \mathrm{lb}\end{array}$ & $\begin{array}{l}\text { Titanium } \\
\text { Reduction, } \\
\quad \%\end{array}$ \\
\hline 10 & 605.43 & 92.70 & 698.13 & 69.81 & 572.67 & 45.06 & 30 & 60 \\
\hline 20 & 1210.86 & 185.40 & 1396.25 & 69.81 & 1145.33 & 45.06 & 60 & 60 \\
\hline 40 & 2421.71 & 370.79 & 2792.51 & 69.81 & 2290.67 & 45.06 & 120 & 60 \\
\hline 60 & 3632.57 & 556.19 & 4188.76 & 69.81 & 3436.00 & 45.06 & 180 & 60 \\
\hline 80 & 4843.43 & 741.59 & 5585.02 & 69.81 & 4581.33 & 45.06 & 240 & 60 \\
\hline 100 & 6054.29 & 926.99 & 6981.27 & 69.81 & 5726.67 & 45.06 & 300 & 60 \\
\hline 200 & 12108.57 & $1,853.97$ & 13962.54 & 69.81 & 11453.34 & 45.06 & 600 & 60 \\
\hline 300 & 18162.86 & $2,780.96$ & 20943.81 & 69.81 & 17180.01 & 45.06 & 900 & 60 \\
\hline 400 & 24217.15 & $3,707.94$ & 27925.09 & 69.81 & 22906.67 & 45.06 & 1200 & 60 \\
\hline 500 & 30271.43 & $4,634.93$ & 34906.36 & 69.81 & 28633.34 & 45.06 & 1500 & 60 \\
\hline 600 & 36325.72 & $5,561.91$ & 41887.63 & 69.81 & 34360.01 & 45.06 & 1800 & 60 \\
\hline 700 & 42380.01 & $6,488.90$ & 48868.90 & 69.81 & 40086.68 & 45.06 & 2100 & 60 \\
\hline 800 & 48434.29 & $7,415.88$ & 55850.17 & 69.81 & 45813.35 & 45.06 & 2400 & 60 \\
\hline 900 & 54488.58 & $8,342.87$ & 62831.44 & 69.81 & 51540.02 & 45.06 & 2700 & 60 \\
\hline 1000 & 60542.86 & $9,269.85$ & 69812.72 & 69.81 & 57266.69 & 45.06 & 3000 & 60 \\
\hline
\end{tabular}




\begin{tabular}{|c|c|c|c|c|c|c|}
\hline \multicolumn{7}{|c|}{$\begin{array}{l}\text { Table 7A. Near Net Shape Machining Preform Cost, B/F from } 5 \text { to } 2 \\
40 \% \text { of Material + Machining Cost Savings Applied to Preform Fabrication }\end{array}$} \\
\hline $\begin{array}{l}\text { Finished } \\
\text { Part } \\
\text { Weight, lb }\end{array}$ & $\begin{array}{l}\text { Savings } 10>2 \\
\text { B/F ratio }\end{array}$ & $\begin{array}{l}\text { Preform } \\
\text { Fabrication } \\
\text { @ } 40 \%\end{array}$ & $\begin{array}{l}\text { Preform } \\
\text { Fabrication } \\
\quad \$ / 1 b\end{array}$ & $\begin{array}{c}\text { Preform } \\
\text { Material Cost, } \\
\$\end{array}$ & $\begin{array}{l}\text { Preform Cost } \\
\$\end{array}$ & $\begin{array}{l}\text { Preform } \\
\text { Cost } \$ / l b\end{array}$ \\
\hline 10 & 818.10 & 327.24 & 16.36 & 360.00 & 687.24 & 34.36 \\
\hline 20 & 1636.19 & 654.48 & 16.36 & 720.00 & 1374.48 & 34.36 \\
\hline 40 & 3272.38 & 1308.95 & 16.36 & 1440.00 & 2748.95 & 34.36 \\
\hline 60 & 4908.57 & 1963.43 & 16.36 & 2160.00 & 4123.43 & 34.36 \\
\hline 80 & 6544.76 & 2617.91 & 16.36 & 2880.00 & 5497.91 & 34.36 \\
\hline 100 & 8180.96 & 3272.38 & 16.36 & 3600.00 & 6872.38 & 34.36 \\
\hline 200 & 16361.91 & 6544.76 & 16.36 & 7200.00 & 13744.76 & 34.36 \\
\hline 300 & 24542.87 & 9817.15 & 16.36 & 10800.00 & 20617.15 & 34.36 \\
\hline 400 & 32723.82 & 13089.53 & 16.36 & 14400.00 & 27489.53 & 34.36 \\
\hline 500 & 40904.78 & 16361.91 & 16.36 & 18000.00 & 34361.91 & 34.36 \\
\hline 600 & 49085.73 & 19634.29 & 16.36 & 21600.00 & 41234.29 & 34.36 \\
\hline 700 & 57266.69 & 22906.67 & 16.36 & 25200.00 & 48106.67 & 34.36 \\
\hline 800 & 65447.64 & 26179.06 & 16.36 & 28800.00 & 54979.06 & 34.36 \\
\hline 900 & 73628.60 & 29451.44 & 16.36 & 32400.00 & 61851.44 & 34.36 \\
\hline 1000 & 81809.55 & 32723.82 & 16.36 & 36000.00 & 68723.82 & 34.36 \\
\hline
\end{tabular}

\begin{tabular}{|c|c|c|c|c|c|c|c|c|}
\hline \multicolumn{9}{|c|}{$\begin{array}{l}\text { Table 7B. Finished Part Cost and Raw Material Reductions, B/F from } 5 \text { to } 2 \\
40 \% \text { of Material + Machining Cost Savings Applied to Preform Fabrication }\end{array}$} \\
\hline $\begin{array}{l}\text { Finished } \\
\text { Part } \\
\text { Weight, } \\
\text { lb }\end{array}$ & $\begin{array}{l}\text { Preform } \\
\text { Cost, } \$\end{array}$ & $\begin{array}{l}\text { Preform } \\
\text { Machining } \\
\text { Cost, } \$\end{array}$ & $\begin{array}{l}\text { Finished } \\
\text { Part Cost, } \$\end{array}$ & $\begin{array}{c}\text { Cost } \\
\text { per Part } \\
\text { Lb, \$ }\end{array}$ & $\begin{array}{c}\text { Cost } \\
\text { Savings, } \$\end{array}$ & $\begin{array}{c}\text { Cost } \\
\text { Savings, } \\
\%\end{array}$ & $\begin{array}{c}\text { Titanium } \\
\text { Reduction, } \\
\text { lb }\end{array}$ & $\begin{array}{c}\text { Titanium } \\
\text { Reduction, } \\
\%\end{array}$ \\
\hline 10 & 687.24 & 92.70 & 779.94 & 77.99 & 490.86 & 38.63 & 30.00 & 60.00 \\
\hline 20 & 1374.48 & 185.40 & 1559.87 & 77.99 & 981.71 & 38.63 & 60.00 & 60.00 \\
\hline 40 & 2748.95 & 370.79 & 3119.75 & 77.99 & 1963.43 & 38.63 & 120.00 & 60.00 \\
\hline 60 & 4123.43 & 556.19 & 4679.62 & 77.99 & 2945.14 & 38.63 & 180.00 & 60.00 \\
\hline 80 & 5497.91 & 741.59 & 6239.49 & 77.99 & 3926.86 & 38.63 & 240.00 & 60.00 \\
\hline 100 & 6872.38 & 926.99 & 7799.37 & 77.99 & 4908.57 & 38.63 & 300.00 & 60.00 \\
\hline 200 & 13744.76 & $1,853.97$ & 15598.73 & 77.99 & 9817.15 & 38.63 & 600.00 & 60.00 \\
\hline 300 & 20617.15 & $2,780.96$ & 23398.10 & 77.99 & 14725.72 & 38.63 & 900.00 & 60.00 \\
\hline 400 & 27489.53 & $3,707.94$ & 31197.47 & 77.99 & 19634.29 & 38.63 & 1200.00 & 60.00 \\
\hline 500 & 34361.91 & $4,634.93$ & 38996.84 & 77.99 & 24542.87 & 38.63 & 1500.00 & 60.00 \\
\hline 600 & 41234.29 & $5,561.91$ & 46796.20 & 77.99 & 29451.44 & 38.63 & 1800.00 & 60.00 \\
\hline 700 & 48106.67 & $6,488.90$ & 54595.57 & 77.99 & 34360.01 & 38.63 & 2100.00 & 60.00 \\
\hline 800 & 54979.06 & $7,415.88$ & 62394.94 & 77.99 & 39268.58 & 38.63 & 2400.00 & 60.00 \\
\hline 900 & 61851.44 & $8,342.87$ & 70194.30 & 77.99 & 44177.16 & 38.63 & 2700.00 & 60.00 \\
\hline 1000 & 68723.82 & $9,269.85$ & 77993.67 & 77.99 & 49085.73 & 38.63 & 3000.00 & 60.00 \\
\hline
\end{tabular}




\begin{tabular}{|c|c|c|c|c|c|c|}
\hline \multicolumn{7}{|c|}{$\begin{array}{l}\text { Table 8A. Near Net Shape Machining Preform Cost, B/F from } 5 \text { to } 2 \\
50 \% \text { of Material + Machining Cost Savings Applied to Preform Fabrication }\end{array}$} \\
\hline $\begin{array}{l}\text { Finished } \\
\text { Part } \\
\text { Weight, lb }\end{array}$ & $\begin{array}{l}\text { Savings5 }>2 \\
\text { B/F ratio }\end{array}$ & $\begin{array}{l}\text { Preform } \\
\text { Fabrication } \\
\text { @ } 50 \%\end{array}$ & $\begin{array}{l}\text { Preform } \\
\text { Fabrication } \\
\quad \$ / 1 b\end{array}$ & $\begin{array}{c}\text { Preform } \\
\text { Material Cost, } \\
\$\end{array}$ & $\begin{array}{l}\text { Preform Cost } \\
\$\end{array}$ & $\begin{array}{l}\text { Preform } \\
\text { Cost } \$ / l b\end{array}$ \\
\hline 10 & 818.10 & 409.05 & 20.45 & 360.00 & 769.05 & 38.45 \\
\hline 20 & 1636.19 & 818.10 & 20.45 & 720.00 & 1538.10 & 38.45 \\
\hline 40 & 3272.38 & 1636.19 & 20.45 & 1440.00 & 3076.19 & 38.45 \\
\hline 60 & 4908.57 & 2454.29 & 20.45 & 2160.00 & 4614.29 & 38.45 \\
\hline 80 & 6544.76 & 3272.38 & 20.45 & 2880.00 & 6152.38 & 38.45 \\
\hline 100 & 8180.96 & 4090.48 & 20.45 & 3600.00 & 7690.48 & 38.45 \\
\hline 200 & 16361.91 & 8180.96 & 20.45 & 7200.00 & 15380.96 & 38.45 \\
\hline 300 & 24542.87 & 12271.43 & 20.45 & 10800.00 & 23071.43 & 38.45 \\
\hline 400 & 32723.82 & 16361.91 & 20.45 & 14400.00 & 30761.91 & 38.45 \\
\hline 500 & 40904.78 & 20452.39 & 20.45 & 18000.00 & 38452.39 & 38.45 \\
\hline 600 & 49085.73 & 24542.87 & 20.45 & 21600.00 & 46142.87 & 38.45 \\
\hline 700 & 57266.69 & 28633.34 & 20.45 & 25200.00 & 53833.34 & 38.45 \\
\hline 800 & 65447.64 & 32723.82 & 20.45 & 28800.00 & 61523.82 & 38.45 \\
\hline 900 & 73628.60 & 36814.30 & 20.45 & 32400.00 & 69214.30 & 38.45 \\
\hline 1000 & 81809.55 & 40904.78 & 20.45 & 36000.00 & 76904.78 & 38.45 \\
\hline
\end{tabular}

\begin{tabular}{|c|c|c|c|c|c|c|c|c|}
\hline \multicolumn{9}{|c|}{$\begin{array}{l}\text { Table 8B. Finished Part Cost and Raw Material Reductions, B/F from } 5 \text { to } 2 \\
50 \% \text { of Material + Machining Cost Savings Applied to Preform Fabrication }\end{array}$} \\
\hline $\begin{array}{c}\text { Finished } \\
\text { Part } \\
\text { Weight, } \\
\text { lb }\end{array}$ & $\begin{array}{c}\text { Preform } \\
\text { Cost, } \$\end{array}$ & $\begin{array}{l}\text { Preform } \\
\text { Machining } \\
\text { Cost, } \$\end{array}$ & $\begin{array}{l}\text { Finished } \\
\text { Part Cost, } \\
\quad \$\end{array}$ & $\begin{array}{c}\text { Cost } \\
\text { per Part } \\
\text { Lb, } \$\end{array}$ & $\begin{array}{c}\text { Cost } \\
\text { Savings, } \$\end{array}$ & $\begin{array}{l}\text { Cost } \\
\text { Savings, } \\
\%\end{array}$ & $\begin{array}{l}\text { Titanium } \\
\text { Reduction, } \\
\quad \mathrm{lb}\end{array}$ & $\begin{array}{l}\text { Titanium } \\
\text { Reduction, } \\
\quad \%\end{array}$ \\
\hline 10 & 769.05 & 92.70 & 861.75 & 86.17 & 409.05 & 32.19 & 30 & 60 \\
\hline 20 & 1538.10 & 185.40 & 1723.49 & 86.17 & 818.10 & 32.19 & 60 & 60 \\
\hline 40 & 3076.19 & 370.79 & 3446.99 & 86.17 & 1636.19 & 32.19 & 120 & 60 \\
\hline 60 & 4614.29 & 556.19 & 5170.48 & 86.17 & 2454.29 & 32.19 & 180 & 60 \\
\hline 80 & 6152.38 & 741.59 & 6893.97 & 86.17 & 3272.38 & 32.19 & 240 & 60 \\
\hline 100 & 7690.48 & 926.99 & 8617.46 & 86.17 & 4090.48 & 32.19 & 300 & 60 \\
\hline 200 & 15380.96 & $1,853.97$ & 17234.93 & 86.17 & 8180.96 & 32.19 & 600 & 60 \\
\hline 300 & 23071.43 & $2,780.96$ & 25852.39 & 86.17 & 12271.43 & 32.19 & 900 & 60 \\
\hline 400 & 30761.91 & $3,707.94$ & 34469.85 & 86.17 & 16361.91 & 32.19 & 1200 & 60 \\
\hline 500 & 38452.39 & $4,634.93$ & 43087.31 & 86.17 & 20452.39 & 32.19 & 1500 & 60 \\
\hline 600 & 46142.87 & $5,561.91$ & 51704.78 & 86.17 & 24542.87 & 32.19 & 1800 & 60 \\
\hline 700 & 53833.34 & $6,488.90$ & 60322.24 & 86.17 & 28633.34 & 32.19 & 2100 & 60 \\
\hline 800 & 61523.82 & $7,415.88$ & 68939.70 & 86.17 & 32723.82 & 32.19 & 2400 & 60 \\
\hline 900 & 69214.30 & $8,342.87$ & 77557.16 & 86.17 & 36814.30 & 32.19 & 2700 & 60 \\
\hline 1000 & 76904.78 & $9,269.85$ & 86174.63 & 86.17 & 40904.78 & 32.19 & 3000 & 60 \\
\hline
\end{tabular}




\begin{tabular}{|c|c|c|c|c|c|c|}
\hline \multicolumn{7}{|c|}{$\begin{array}{l}\text { Table 9A. Near Net Shape Machining Preform Cost, B/F from } 5 \text { to } 2 \\
60 \% \text { of Material + Machining Cost Savings Applied to Preform Fabrication }\end{array}$} \\
\hline $\begin{array}{l}\text { Finished } \\
\text { Part } \\
\text { Weight, lb }\end{array}$ & $\begin{array}{l}\text { Savings } 10>2 \\
\text { B/F ratio }\end{array}$ & $\begin{array}{l}\text { Preform } \\
\text { Fabrication } \\
\text { @60\% }\end{array}$ & $\begin{array}{l}\text { Preform } \\
\text { Fabrication } \\
\quad \$ / 1 b\end{array}$ & $\begin{array}{c}\text { Preform } \\
\text { Material Cost, } \\
\$\end{array}$ & $\begin{array}{l}\text { Preform Cost } \\
\$\end{array}$ & $\begin{array}{l}\text { Preform } \\
\text { Cost } \$ / 1 b\end{array}$ \\
\hline 10 & 818.10 & 490.86 & 24.54 & 360.00 & 850.86 & 42.54 \\
\hline 20 & 1636.19 & 981.71 & 24.54 & 720.00 & 1701.71 & 42.54 \\
\hline 40 & 3272.38 & 1963.43 & 24.54 & 1440.00 & 3403.43 & 42.54 \\
\hline 60 & 4908.57 & 2945.14 & 24.54 & 2160.00 & 5105.14 & 42.54 \\
\hline 80 & 6544.76 & 3926.86 & 24.54 & 2880.00 & 6806.86 & 42.54 \\
\hline 100 & 8180.96 & 4908.57 & 24.54 & 3600.00 & 8508.57 & 42.54 \\
\hline 200 & 16361.91 & 9817.15 & 24.54 & 7200.00 & 17017.15 & 42.54 \\
\hline 300 & 24542.87 & 14725.72 & 24.54 & 10800.00 & 25525.72 & 42.54 \\
\hline 400 & 32723.82 & 19634.29 & 24.54 & 14400.00 & 34034.29 & 42.54 \\
\hline 500 & 40904.78 & 24542.87 & 24.54 & 18000.00 & 42542.86 & 42.54 \\
\hline 600 & 49085.73 & 29451.44 & 24.54 & 21600.00 & 51051.44 & 42.54 \\
\hline 700 & 57266.69 & 34360.01 & 24.54 & 25200.00 & 59560.01 & 42.54 \\
\hline 800 & 65447.64 & 39268.58 & 24.54 & 28800.00 & 68068.58 & 42.54 \\
\hline 900 & 73628.60 & 44177.16 & 24.54 & 32400.00 & 76577.16 & 42.54 \\
\hline 1000 & 81809.55 & 49085.73 & 24.54 & 36000.00 & 85085.73 & 42.54 \\
\hline
\end{tabular}

\begin{tabular}{|c|c|c|c|c|c|c|c|c|}
\hline \multicolumn{9}{|c|}{$\begin{array}{l}\text { Table 9B. Finished Part Cost and Raw Material Reductions, B/F from } 5 \text { to } 2 \\
60 \% \text { of Material + Machining Cost Savings Applied to Preform Fabrication }\end{array}$} \\
\hline $\begin{array}{c}\text { Finished } \\
\text { Part } \\
\text { Weight, } \\
\text { lb }\end{array}$ & $\begin{array}{l}\text { Preform } \\
\text { Cost, } \$\end{array}$ & $\begin{array}{l}\text { Preform } \\
\text { Machining } \\
\text { Cost, } \$\end{array}$ & $\begin{array}{l}\text { Finished } \\
\text { Part Cost, } \$\end{array}$ & $\begin{array}{l}\text { Cost } \\
\text { per Part } \\
\text { Lb, \$ }\end{array}$ & $\begin{array}{c}\text { Cost } \\
\text { Savings, } \$\end{array}$ & $\begin{array}{c}\text { Cost } \\
\text { Savings, } \\
\%\end{array}$ & $\begin{array}{c}\text { Titanium } \\
\text { Reduction, } \\
\text { lb }\end{array}$ & $\begin{array}{c}\text { Titanium } \\
\text { Reduction, } \\
\%\end{array}$ \\
\hline 10 & 850.86 & 92.70 & 943.56 & 94.36 & 327.24 & 25.75 & 30.00 & 60.00 \\
\hline 20 & 1701.71 & 185.40 & 1887.11 & 94.36 & 654.48 & 25.75 & 60.00 & 60.00 \\
\hline 40 & 3403.43 & 370.79 & 3774.22 & 94.36 & 1308.95 & 25.75 & 120.00 & 60.00 \\
\hline 60 & 5105.14 & 556.19 & 5661.33 & 94.36 & 1963.43 & 25.75 & 180.00 & 60.00 \\
\hline 80 & 6806.86 & 741.59 & 7548.45 & 94.36 & 2617.91 & 25.75 & 240.00 & 60.00 \\
\hline 100 & 8508.57 & 926.99 & 9435.56 & 94.36 & 3272.38 & 25.75 & 300.00 & 60.00 \\
\hline 200 & 17017.15 & $1,853.97$ & 18871.12 & 94.36 & 6544.76 & 25.75 & 600.00 & 60.00 \\
\hline 300 & 25525.72 & $2,780.96$ & 28306.67 & 94.36 & 9817.15 & 25.75 & 900.00 & 60.00 \\
\hline 400 & 34034.29 & $3,707.94$ & 37742.23 & 94.36 & 13089.53 & 25.75 & 1200.00 & 60.00 \\
\hline 500 & 42542.86 & $4,634.93$ & 47177.79 & 94.36 & 16361.91 & 25.75 & 1500.00 & 60.00 \\
\hline 600 & 51051.44 & $5,561.91$ & 56613.35 & 94.36 & 19634.29 & 25.75 & 1800.00 & 60.00 \\
\hline 700 & 59560.01 & $6,488.90$ & 66048.91 & 94.36 & 22906.67 & 25.75 & 2100.00 & 60.00 \\
\hline 800 & 68068.58 & $7,415.88$ & 75484.46 & 94.36 & 26179.06 & 25.75 & 2400.00 & 60.00 \\
\hline 900 & 76577.16 & $8,342.87$ & 84920.02 & 94.36 & 29451.44 & 25.75 & 2700.00 & 60.00 \\
\hline 1000 & 85085.73 & $9,269.85$ & 94355.58 & 94.36 & 32723.82 & 25.75 & 3000.00 & 60.00 \\
\hline
\end{tabular}




\begin{tabular}{|c|c|c|c|c|c|c|}
\hline \multicolumn{7}{|c|}{$\begin{array}{l}\text { Table 10A. Near Net Shape Machining Preform Cost, B/F from } 5 \text { to } 2 \\
70 \% \text { of Material + Machining Cost Savings Applied to Preform Fabrication }\end{array}$} \\
\hline $\begin{array}{l}\text { Finished } \\
\text { Part } \\
\text { Weight, lb }\end{array}$ & $\begin{array}{l}\text { Savings } 10>2 \\
\text { B/F ratio }\end{array}$ & $\begin{array}{l}\text { Preform } \\
\text { Fabrication } \\
\text { @ } 70 \%\end{array}$ & $\begin{array}{l}\text { Preform } \\
\text { Fabrication } \\
\quad \$ / 1 b\end{array}$ & $\begin{array}{c}\text { Preform } \\
\text { Material Cost, } \\
\$\end{array}$ & $\begin{array}{l}\text { Preform Cost } \\
\$\end{array}$ & $\begin{array}{l}\text { Preform } \\
\text { Cost } \$ / l b\end{array}$ \\
\hline 10 & 818.10 & 572.67 & 28.63 & 360 & 932.67 & 46.63 \\
\hline 20 & 1636.19 & 1145.33 & 28.63 & 720 & 1865.33 & 46.63 \\
\hline 40 & 3272.38 & 2290.67 & 28.63 & 1440 & 3730.67 & 46.63 \\
\hline 60 & 4908.57 & 3436.00 & 28.63 & 2160 & 5596.00 & 46.63 \\
\hline 80 & 6544.76 & 4581.33 & 28.63 & 2880 & 7461.33 & 46.63 \\
\hline 100 & 8180.96 & 5726.67 & 28.63 & 3600 & 9326.67 & 46.63 \\
\hline 200 & 16361.91 & 11453.34 & 28.63 & 7200 & 18653.34 & 46.63 \\
\hline 300 & 24542.87 & 17180.01 & 28.63 & 10800 & 27980.01 & 46.63 \\
\hline 400 & 32723.82 & 22906.67 & 28.63 & 14400 & 37306.67 & 46.63 \\
\hline 500 & 40904.78 & 28633.34 & 28.63 & 18000 & 46633.34 & 46.63 \\
\hline 600 & 49085.73 & 34360.01 & 28.63 & 21600 & 55960.01 & 46.63 \\
\hline 700 & 57266.69 & 40086.68 & 28.63 & 25200 & 65286.68 & 46.63 \\
\hline 800 & 65447.64 & 45813.35 & 28.63 & 28800 & 74613.35 & 46.63 \\
\hline 900 & 73628.60 & 51540.02 & 28.63 & 32400 & 83940.02 & 46.63 \\
\hline 1000 & 81809.55 & 57266.69 & 28.63 & 36000 & 93266.69 & 46.63 \\
\hline
\end{tabular}

\begin{tabular}{|c|c|c|c|c|c|c|c|c|}
\hline \multicolumn{9}{|c|}{$\begin{array}{l}\text { Table 10B. Finished Part Cost and Raw Material Reductions, B/F from } 5 \text { to } 2 \\
70 \% \text { of Material + Machining Cost Savings Applied to Preform Fabrication }\end{array}$} \\
\hline $\begin{array}{l}\text { Finished } \\
\text { Part } \\
\text { Weight, } \\
\text { lb }\end{array}$ & $\begin{array}{l}\text { Preform } \\
\text { Cost, } \$\end{array}$ & $\begin{array}{l}\text { Preform } \\
\text { Machining } \\
\text { Cost, } \$\end{array}$ & $\begin{array}{l}\text { Finished } \\
\text { Part Cost, \$ }\end{array}$ & $\begin{array}{c}\text { Cost } \\
\text { per Part } \\
\text { Lb, \$ }\end{array}$ & $\begin{array}{c}\text { Cost } \\
\text { Savings, } \$\end{array}$ & $\begin{array}{c}\text { Cost } \\
\text { Savings, } \\
\%\end{array}$ & $\begin{array}{c}\text { Titanium } \\
\text { Reduction, } \\
\mathrm{lb}\end{array}$ & $\begin{array}{c}\text { Titanium } \\
\text { Reduction, } \\
\%\end{array}$ \\
\hline 10 & 932.67 & 92.70 & 1025.37 & 102.54 & 245.43 & 19.31 & 30.00 & 60.00 \\
\hline 20 & 1865.33 & 185.40 & 2050.73 & 102.54 & 490.86 & 19.31 & 60.00 & 60.00 \\
\hline 40 & 3730.67 & 370.79 & 4101.46 & 102.54 & 981.71 & 19.31 & 120.00 & 60.00 \\
\hline 60 & 5596.00 & 556.19 & 6152.19 & 102.54 & 1472.57 & 19.31 & 180.00 & 60.00 \\
\hline 80 & 7461.33 & 741.59 & 8202.92 & 102.54 & 1963.43 & 19.31 & 240.00 & 60.00 \\
\hline 100 & 9326.67 & 926.99 & 10253.65 & 102.54 & 2454.29 & 19.31 & 300.00 & 60.00 \\
\hline 200 & 18653.34 & $1,853.97$ & 20507.31 & 102.54 & 4908.57 & 19.31 & 600.00 & 60.00 \\
\hline 300 & 27980.01 & $2,780.96$ & 30760.96 & 102.54 & 7362.86 & 19.31 & 900.00 & 60.00 \\
\hline 400 & 37306.67 & $3,707.94$ & 41014.61 & 102.54 & 9817.15 & 19.31 & 1200.00 & 60.00 \\
\hline 500 & 46633.34 & $4,634.93$ & 51268.27 & 102.54 & 12271.43 & 19.31 & 1500.00 & 60.00 \\
\hline 600 & 55960.01 & $5,561.91$ & 61521.92 & 102.54 & 14725.72 & 19.31 & 1800.00 & 60.00 \\
\hline 700 & 65286.68 & $6,488.90$ & 71775.57 & 102.54 & 17180.01 & 19.31 & 2100.00 & 60.00 \\
\hline 800 & 74613.35 & $7,415.88$ & 82029.23 & 102.54 & 19634.29 & 19.31 & 2400.00 & 60.00 \\
\hline 900 & 83940.02 & $8,342.87$ & 92282.88 & 102.54 & 22088.58 & 19.31 & 2700.00 & 60.00 \\
\hline 1000 & 93266.69 & $9,269.85$ & 102536.54 & 102.54 & 24542.87 & 19.31 & 3000.00 & 60.00 \\
\hline
\end{tabular}




\begin{tabular}{|c|c|c|c|c|c|c|}
\hline \multicolumn{7}{|c|}{$\begin{array}{l}\text { Table } 11 \mathrm{~A} . \text { Near Net Shape Machining Preform Cost, B/F from } 10 \text { to } 2 \\
30 \% \text { of Material + Machining Cost Savings Applied to Preform Fabrication }\end{array}$} \\
\hline $\begin{array}{l}\text { Finished } \\
\text { Part } \\
\text { Weight, lb }\end{array}$ & $\begin{array}{l}\text { Savings } 10>2 \\
\text { B/F ratio }\end{array}$ & $\begin{array}{l}\text { Preform } \\
\text { Fabrication } \\
\quad @ 30 \%\end{array}$ & $\begin{array}{l}\text { Preform } \\
\text { Fabrication } \\
\quad \$ / l b\end{array}$ & $\begin{array}{c}\text { Preform } \\
\text { Material Cost, } \\
\$\end{array}$ & $\underset{\$}{\text { Preform Cost }}$ & $\begin{array}{l}\text { Preform } \\
\text { Cost } \$ / 1 b\end{array}$ \\
\hline 10 & 2181.59 & 654.48 & 32.72 & 360 & 1014.48 & 50.72 \\
\hline 20 & 4363.18 & 1308.95 & 32.72 & 720 & 2028.95 & 50.72 \\
\hline 40 & 8726.35 & 2617.91 & 32.72 & 1440 & 4057.91 & 50.72 \\
\hline 60 & 13089.53 & 3926.86 & 32.72 & 2160 & 6086.86 & 50.72 \\
\hline 80 & 17452.7 & 5235.81 & 32.72 & 2880 & 8115.81 & 50.72 \\
\hline 100 & 21815.88 & 6544.76 & 32.72 & 3600 & 10144.76 & 50.72 \\
\hline 200 & 43631.76 & 13089.53 & 32.72 & 7200 & 20289.53 & 50.72 \\
\hline 300 & 65447.64 & 19634.29 & 32.72 & 10800 & 30434.29 & 50.72 \\
\hline 400 & 87263.52 & 26179.06 & 32.72 & 14400 & 40579.06 & 50.72 \\
\hline 500 & 109079.4 & 32723.82 & 32.72 & 18000 & 50723.82 & 50.72 \\
\hline 600 & 130895.28 & 39268.58 & 32.72 & 21600 & 60868.58 & 50.72 \\
\hline 700 & 152711.16 & 45813.35 & 32.72 & 25200 & 71013.35 & 50.72 \\
\hline 800 & 174527.04 & 52358.11 & 32.72 & 28800 & 81158.11 & 50.72 \\
\hline 900 & 196342.92 & 58902.88 & 32.72 & 32400 & 91302.88 & 50.72 \\
\hline 1000 & 218158.8 & 65447.64 & 32.72 & 36000 & 101447.64 & 50.72 \\
\hline
\end{tabular}

\begin{tabular}{|c|c|c|c|c|c|c|c|c|}
\hline \multicolumn{9}{|c|}{$\begin{array}{l}\text { Table 11B. Finished Part Cost and Raw Material Reductions, B/F from } 10 \text { to } 2 \\
30 \% \text { of Material + Machining Cost Savings Applied to Preform Fabrication }\end{array}$} \\
\hline $\begin{array}{c}\text { Finished } \\
\text { Part } \\
\text { Weight, } \\
\text { lb }\end{array}$ & $\begin{array}{l}\text { Preform } \\
\text { Cost, } \$\end{array}$ & $\begin{array}{l}\text { Preform } \\
\text { Machining } \\
\text { Cost, } \$\end{array}$ & $\begin{array}{l}\text { Finished } \\
\text { Part Cost, } \$\end{array}$ & $\begin{array}{c}\text { Cost } \\
\text { per Part } \\
\text { Lb, \$ }\end{array}$ & $\begin{array}{c}\text { Cost } \\
\text { Savings, } \$\end{array}$ & $\begin{array}{c}\text { Cost } \\
\text { Savings, } \\
\%\end{array}$ & $\begin{array}{c}\text { Titanium } \\
\text { Reduction, } \\
\mathrm{lb}\end{array}$ & $\begin{array}{c}\text { Titanium } \\
\text { Reduction, } \\
\%\end{array}$ \\
\hline 10 & 1014.48 & 92.70 & 1107.18 & 110.72 & 1527.11 & 58.0 & 80 & 80 \\
\hline 20 & 2028.95 & 185.40 & 2214.35 & 110.72 & 3054.22 & 58.0 & 160 & 80 \\
\hline 40 & 4057.91 & 370.79 & 4428.70 & 110.72 & 6108.45 & 58.0 & 320 & 80 \\
\hline 60 & 6086.86 & 556.19 & 6643.05 & 110.72 & 9162.669 & 58.0 & 480 & 80 \\
\hline 80 & 8115.81 & 741.59 & 8857.40 & 110.72 & 12216.89 & 58.0 & 640 & 80 \\
\hline 100 & 10144.76 & 926.99 & 11071.75 & 110.72 & 15271.12 & 58.0 & 800 & 80 \\
\hline 200 & 20289.53 & $1,853.97$ & $22,143.50$ & 110.72 & $30,542.23$ & 58.0 & 1600 & 80 \\
\hline 300 & 30434.29 & $2,780.96$ & $33,215.25$ & 110.72 & $45,813.35$ & 58.0 & 2400 & 80 \\
\hline 400 & 40579.06 & $3,707.94$ & $44,287.00$ & 110.72 & $61,084.46$ & 58.0 & 3200 & 80 \\
\hline 500 & 50723.82 & $4,634.93$ & $55,358.75$ & 110.72 & $76,355.58$ & 58.0 & 4000 & 80 \\
\hline 600 & 60868.58 & $5,561.91$ & $66,430.49$ & 110.72 & $91,626.70$ & 58.0 & 4800 & 80 \\
\hline 700 & 71013.35 & $6,488.90$ & $77,502.25$ & 110.72 & $106,897.81$ & 58.0 & 5600 & 80 \\
\hline 800 & 81158.11 & $7,415.88$ & $88,573.99$ & 110.72 & $122,168.93$ & 58.0 & 6400 & 80 \\
\hline 900 & 91302.88 & $8,342.87$ & $99,645.75$ & 110.72 & $137,440.04$ & 58.0 & 7200 & 80 \\
\hline 1000 & 101447.64 & $9,269.85$ & $110,717.49$ & 110.72 & $152,711.16$ & 58.0 & 8000 & 80 \\
\hline
\end{tabular}




\begin{tabular}{|c|c|c|c|c|c|c|}
\hline \multicolumn{7}{|c|}{$\begin{array}{l}\text { Table 12A. Near Net Shape Machining Preform Cost, B/F from } 10 \text { to } 2 \\
40 \% \text { of Material + Machining Cost Savings Applied to Preform Fabrication }\end{array}$} \\
\hline $\begin{array}{l}\text { Finished } \\
\text { Part } \\
\text { Weight, lb }\end{array}$ & $\begin{array}{l}\text { Savings } 10>2 \\
\text { B/F ratio }\end{array}$ & $\begin{array}{l}\text { Preform } \\
\text { Fabrication } \\
\quad @ 40 \%\end{array}$ & $\begin{array}{l}\text { Preform } \\
\text { Fabrication } \\
\quad \$ / l b\end{array}$ & $\begin{array}{c}\text { Preform } \\
\text { Material Cost, } \\
\$\end{array}$ & $\underset{\$}{\text { Preform Cost }}$ & $\begin{array}{l}\text { Preform } \\
\text { Cost } \$ / l b\end{array}$ \\
\hline 10 & 2181.59 & 872.64 & 43.63 & 360 & 1232.64 & 61.63 \\
\hline 20 & 4363.18 & 1745.27 & 43.63 & 720 & 2465.27 & 61.63 \\
\hline 40 & 8726.35 & 3490.54 & 43.63 & 1440 & 4930.54 & 61.63 \\
\hline 60 & 13089.53 & 5235.81 & 43.63 & 2160 & 7395.81 & 61.63 \\
\hline 80 & 17452.7 & 6981.08 & 43.63 & 2880 & 9861.08 & 61.63 \\
\hline 100 & 21815.88 & 8726.35 & 43.63 & 3600 & 12326.35 & 61.63 \\
\hline 200 & 43631.76 & 17452.70 & 43.63 & 7200 & 24652.70 & 61.63 \\
\hline 300 & 65447.64 & 26179.06 & 43.63 & 10800 & 36979.06 & 61.63 \\
\hline 400 & 87263.52 & 34905.41 & 43.63 & 14400 & 49305.41 & 61.63 \\
\hline 500 & 109079.4 & 43631.76 & 43.63 & 18000 & 61631.76 & 61.63 \\
\hline 600 & 130895.28 & 52358.11 & 43.63 & 21600 & 73958.11 & 61.63 \\
\hline 700 & 152711.16 & 61084.46 & 43.63 & 25200 & 86284.46 & 61.63 \\
\hline 800 & 174527.04 & 69810.82 & 43.63 & 28800 & 98610.82 & 61.63 \\
\hline 900 & 196342.92 & 78537.17 & 43.63 & 32400 & 110937.17 & 61.63 \\
\hline 1000 & 218158.8 & 87263.52 & 43.63 & 36000 & 123263.52 & 61.63 \\
\hline
\end{tabular}

\begin{tabular}{|c|c|c|c|c|c|c|c|c|}
\hline \multicolumn{9}{|c|}{$\begin{array}{l}\text { Table 12B. Finished Part Cost and Raw Material Reductions, B/F from } 10 \text { to } 2 \\
40 \% \text { of Material + Machining Cost Savings Applied to Preform Fabrication }\end{array}$} \\
\hline $\begin{array}{l}\text { Finished } \\
\text { Part } \\
\text { Weight, } \\
\text { lb }\end{array}$ & $\begin{array}{l}\text { Preform } \\
\text { Cost, } \$\end{array}$ & $\begin{array}{l}\text { Preform } \\
\text { Machining } \\
\text { Cost, } \$\end{array}$ & $\begin{array}{l}\text { Finished } \\
\text { Part Cost, } \$\end{array}$ & $\begin{array}{c}\text { Cost } \\
\text { per Part } \\
\text { Lb, \$ }\end{array}$ & $\begin{array}{c}\text { Cost } \\
\text { Savings, } \$\end{array}$ & $\begin{array}{c}\text { Cost } \\
\text { Savings, } \\
\%\end{array}$ & $\begin{array}{c}\text { Titanium } \\
\text { Reduction, } \\
\text { lb }\end{array}$ & $\begin{array}{c}\text { Titanium } \\
\text { Reduction, } \\
\%\end{array}$ \\
\hline 10 & 1232.64 & 92.70 & 1325.34 & 132.53 & 1308.95 & 49.7 & 80 & 80 \\
\hline 20 & 2465.27 & 185.40 & 2650.67 & 132.53 & 2617.90 & 49.7 & 160 & 80 \\
\hline 40 & 4930.54 & 370.79 & 5301.33 & 132.53 & 5235.82 & 49.7 & 320 & 80 \\
\hline 60 & 7395.81 & 556.19 & 7952 & 132.53 & 7853.72 & 49.7 & 480 & 80 \\
\hline 80 & 9861.08 & 741.59 & 10602.67 & 132.53 & 10471.62 & 49.7 & 640 & 80 \\
\hline 100 & 12326.35 & 926.99 & 13253.34 & 132.53 & 13089.53 & 49.7 & 800 & 80 \\
\hline 200 & 24652.70 & $1,853.97$ & $26,506.67$ & 132.53 & $26,179.06$ & 49.7 & 1600 & 80 \\
\hline 300 & 36979.06 & $2,780.96$ & $39,760.02$ & 132.53 & $39,268.58$ & 49.7 & 2400 & 80 \\
\hline 400 & 49305.41 & $3,707.94$ & $53,013.35$ & 132.53 & $52,358.11$ & 49.7 & 3200 & 80 \\
\hline 500 & 61631.76 & $4,634.93$ & $66,266.69$ & 132.53 & $65,447.64$ & 49.7 & 4000 & 80 \\
\hline 600 & 73958.11 & $5,561.91$ & $79,520.02$ & 132.53 & $78,537.17$ & 49.7 & 4800 & 80 \\
\hline 700 & 86284.46 & $6,488.90$ & $92,773.36$ & 132.53 & $91,626.70$ & 49.7 & 5600 & 80 \\
\hline 800 & 98610.82 & $7,415.88$ & $106,026.70$ & 132.53 & $104,716.22$ & 49.7 & 6400 & 80 \\
\hline 900 & 110937.17 & $8,342.87$ & $119,280.04$ & 132.53 & $117,805.75$ & 49.7 & 7200 & 80 \\
\hline 1000 & 123263.52 & $9,269.85$ & $132,533.37$ & 132.53 & $130,895.28$ & 49.7 & 8000 & 80 \\
\hline
\end{tabular}




\begin{tabular}{|c|c|c|c|c|c|c|}
\hline \multicolumn{7}{|c|}{$\begin{array}{l}\text { Table 13A. Near Net Shape Machining Preform Cost, B/F from } 10 \text { to } 2 \\
50 \% \text { of Material + Machining Cost Savings Applied to Preform Fabrication }\end{array}$} \\
\hline $\begin{array}{l}\text { Finished } \\
\text { Part } \\
\text { Weight, lb }\end{array}$ & $\begin{array}{l}\text { Savings } 10>2 \\
\text { B/F ratio }\end{array}$ & $\begin{array}{l}\text { Preform } \\
\text { Fabrication } \\
\quad @ 50 \%\end{array}$ & $\begin{array}{l}\text { Preform } \\
\text { Fabrication } \\
\quad \$ / l b\end{array}$ & $\begin{array}{c}\text { Preform } \\
\text { Material Cost, } \\
\$\end{array}$ & $\underset{\$}{\text { Preform Cost }}$ & $\begin{array}{l}\text { Preform } \\
\text { Cost } \$ / l b\end{array}$ \\
\hline 10 & 2181.59 & 1090.79 & 54.54 & 360 & 1450.79 & 72.54 \\
\hline 20 & 4363.18 & 2181.59 & 54.54 & 720 & 2901.59 & 72.54 \\
\hline 40 & 8726.35 & 4363.18 & 54.54 & 1440 & 5803.18 & 72.54 \\
\hline 60 & 13089.53 & 6544.76 & 54.54 & 2160 & 8704.76 & 72.54 \\
\hline 80 & 17452.7 & 8726.35 & 54.54 & 2880 & 11606.35 & 72.54 \\
\hline 100 & 21815.88 & 10907.94 & 54.54 & 3600 & 14507.94 & 72.54 \\
\hline 200 & 43631.76 & 21815.88 & 54.54 & 7200 & 29015.88 & 72.54 \\
\hline 300 & 65447.64 & 32723.82 & 54.54 & 10800 & 43523.82 & 72.54 \\
\hline 400 & 87263.52 & 43631.76 & 54.54 & 14400 & 58031.76 & 72.54 \\
\hline 500 & 109079.4 & 54539.7 & 54.54 & 18000 & 72539.7 & 72.54 \\
\hline 600 & 130895.28 & 65447.64 & 54.54 & 21600 & 87047.64 & 72.54 \\
\hline 700 & 152711.16 & 76355.58 & 54.54 & 25200 & 101555.58 & 72.54 \\
\hline 800 & 174527.04 & 87263.52 & 54.54 & 28800 & 116063.52 & 72.54 \\
\hline 900 & 196342.92 & 98171.46 & 54.54 & 32400 & 130571.46 & 72.54 \\
\hline 1000 & 218158.8 & 109079.4 & 54.54 & 36000 & 145079.4 & 72.54 \\
\hline
\end{tabular}

\begin{tabular}{|c|c|c|c|c|c|c|c|c|}
\hline \multicolumn{9}{|c|}{$\begin{array}{l}\text { Table 13B. Finished Part Cost and Raw Material Reductions, B/F from } 10 \text { to } 2 \\
50 \% \text { of Material + Machining Cost Savings Applied to Preform Fabrication }\end{array}$} \\
\hline $\begin{array}{c}\text { Finished } \\
\text { Part } \\
\text { Weight, } \\
\text { lb }\end{array}$ & $\begin{array}{l}\text { Preform } \\
\text { Cost, } \$\end{array}$ & $\begin{array}{l}\text { Preform } \\
\text { Machining } \\
\text { Cost, } \$\end{array}$ & $\begin{array}{l}\text { Finished } \\
\text { Part Cost, } \\
\quad \$\end{array}$ & $\begin{array}{c}\text { Cost } \\
\text { per Part } \\
\text { Lb, \$ }\end{array}$ & $\begin{array}{c}\text { Cost } \\
\text { Savings, } \$\end{array}$ & $\begin{array}{c}\text { Cost } \\
\text { Savings, } \\
\%\end{array}$ & $\begin{array}{c}\text { Titanium } \\
\text { Reduction, } \\
\text { lb }\end{array}$ & $\begin{array}{c}\text { Titanium } \\
\text { Reduction, } \\
\%\end{array}$ \\
\hline 10 & 1450.79 & 92.70 & 1543.49 & 154.35 & 1090.80 & 41.4 & 80 & 80 \\
\hline 20 & 2901.59 & 185.40 & 3086.99 & 154.35 & 2181.58 & 41.4 & 160 & 80 \\
\hline 40 & 5803.18 & 370.79 & 6173.97 & 154.35 & 4363.18 & 41.4 & 320 & 80 \\
\hline 60 & 8704.76 & 556.19 & 9260.95 & 154.35 & 6544.77 & 41.4 & 480 & 80 \\
\hline 80 & 11606.35 & 741.59 & 12347.94 & 154.35 & 8726.35 & 41.4 & 640 & 80 \\
\hline 100 & 14507.94 & 926.99 & 15434.93 & 154.35 & 10907.94 & 41.4 & 800 & 80 \\
\hline 200 & 29015.88 & $1,853.97$ & $30,869.85$ & 154.35 & $21,815.88$ & 41.4 & 1600 & 80 \\
\hline 300 & 43523.82 & $2,780.96$ & $46,304.78$ & 154.35 & $32,723.82$ & 41.4 & 2400 & 80 \\
\hline 400 & 58031.76 & $3,707.94$ & $61,739.70$ & 154.35 & $43,631.76$ & 41.4 & 3200 & 80 \\
\hline 500 & 72539.7 & $4,634.93$ & $77,174.63$ & 154.35 & $54,539.70$ & 41.4 & 4000 & 80 \\
\hline 600 & 87047.64 & $5,561.91$ & $92,609.55$ & 154.35 & $65,447.64$ & 41.4 & 4800 & 80 \\
\hline 700 & 101555.58 & $6,488.90$ & $108,044.48$ & 154.35 & $76,355.58$ & 41.4 & 5600 & 80 \\
\hline 800 & 116063.52 & $7,415.88$ & $123,479.40$ & 154.35 & $87,263.52$ & 41.4 & 6400 & 80 \\
\hline 900 & 130571.46 & $8,342.87$ & $138,914.33$ & 154.35 & $98,171.46$ & 41.4 & 7200 & 80 \\
\hline 1000 & 145079.4 & $9,269.85$ & $154,349.25$ & 154.35 & $109,079.40$ & 41.4 & 8000 & 80 \\
\hline
\end{tabular}




\begin{tabular}{|c|c|c|c|c|c|c|}
\hline \multicolumn{7}{|c|}{$\begin{array}{l}\text { Table 14A. Near Net Shape Machining Preform Cost, B/F from } 10 \text { to } 2 \\
60 \% \text { of Material + Machining Cost Savings Applied to Preform Fabrication }\end{array}$} \\
\hline $\begin{array}{l}\text { Finished } \\
\text { Part } \\
\text { Weight, lb }\end{array}$ & $\begin{array}{l}\text { Savings } 10>2 \\
\text { B/F ratio }\end{array}$ & $\begin{array}{l}\text { Preform } \\
\text { Fabrication } \\
\text { @60\% }\end{array}$ & $\begin{array}{l}\text { Preform } \\
\text { Fabrication } \\
\quad \$ / 1 b\end{array}$ & $\begin{array}{c}\text { Preform } \\
\text { Material Cost, } \\
\$\end{array}$ & $\begin{array}{l}\text { Preform Cost } \\
\$\end{array}$ & $\begin{array}{l}\text { Preform } \\
\text { Cost } \$ / 1 b\end{array}$ \\
\hline 10 & 2181.59 & 1308.95 & 65.45 & 360 & 1668.95 & 83.45 \\
\hline 20 & 4363.18 & 2617.91 & 65.45 & 720 & 3337.91 & 83.45 \\
\hline 40 & 8726.35 & 5235.81 & 65.45 & 1440 & 6675.81 & 83.45 \\
\hline 60 & 13089.53 & 7853.72 & 65.45 & 2160 & 10013.72 & 83.45 \\
\hline 80 & 17452.7 & 10471.62 & 65.45 & 2880 & 13351.62 & 83.45 \\
\hline 100 & 21815.88 & 13089.53 & 65.45 & 3600 & 16689.53 & 83.45 \\
\hline 200 & 43631.76 & 26179.06 & 65.45 & 7200 & 33379.06 & 83.45 \\
\hline 300 & 65447.64 & 39268.58 & 65.45 & 10800 & 50068.58 & 83.45 \\
\hline 400 & 87263.52 & 52358.11 & 65.45 & 14400 & 66758.11 & 83.45 \\
\hline 500 & 109079.4 & 65447.64 & 65.45 & 18000 & 83447.64 & 83.45 \\
\hline 600 & 130895.28 & 78537.17 & 65.45 & 21600 & 100137.17 & 83.45 \\
\hline 700 & 152711.16 & 91626.70 & 65.45 & 25200 & 116826.70 & 83.45 \\
\hline 800 & 174527.04 & 104716.22 & 65.45 & 28800 & 133516.22 & 83.45 \\
\hline 900 & 196342.92 & 117805.75 & 65.45 & 32400 & 150205.75 & 83.45 \\
\hline 1000 & 218158.8 & 130895.28 & 65.45 & 36000 & 166895.28 & 83.45 \\
\hline
\end{tabular}

\begin{tabular}{|c|c|c|c|c|c|c|c|c|}
\hline \multicolumn{9}{|c|}{$\begin{array}{l}\text { Table 14B. Finished Part Cost and Raw Material Reductions, B/F from } 10 \text { to } 2 \\
60 \% \text { of Material + Machining Cost Savings Applied to Preform Fabrication }\end{array}$} \\
\hline $\begin{array}{c}\text { Finished } \\
\text { Part } \\
\text { Weight, } \\
\text { lb }\end{array}$ & $\begin{array}{l}\text { Preform } \\
\text { Cost, } \$\end{array}$ & $\begin{array}{l}\text { Preform } \\
\text { Machining } \\
\text { Cost, } \$\end{array}$ & $\begin{array}{l}\text { Finished } \\
\text { Part Cost, \$ }\end{array}$ & $\begin{array}{c}\text { Cost } \\
\text { per Part } \\
\text { Lb, \$ }\end{array}$ & $\begin{array}{c}\text { Cost } \\
\text { Savings, } \$\end{array}$ & $\begin{array}{c}\text { Cost } \\
\text { Savings, } \\
\%\end{array}$ & $\begin{array}{c}\text { Titanium } \\
\text { Reduction, } \\
\text { lb }\end{array}$ & $\begin{array}{c}\text { Titanium } \\
\text { Reduction, } \\
\%\end{array}$ \\
\hline 10 & 1668.95 & 92.70 & 1761.65 & 176.17 & 872.64 & 33.13 & 80 & 80 \\
\hline 20 & 3337.91 & 185.40 & 3523.31 & 176.17 & 1745.26 & 31.13 & 160 & 80 \\
\hline 40 & 6675.81 & 370.79 & 7046.60 & 176.17 & 3490.55 & 33.13 & 320 & 80 \\
\hline 60 & 10013.72 & 556.19 & 10569.91 & 176.17 & 5235.81 & 31.13 & 480 & 80 \\
\hline 80 & 13351.62 & 741.59 & 14093.21 & 176.17 & 6981.08 & 33.13 & 640 & 80 \\
\hline 100 & 16689.53 & 926.99 & 17616.52 & 176.17 & 8726.35 & 31.13 & 800 & 80 \\
\hline 200 & 33379.06 & $1,853.97$ & $35,233.03$ & 176.17 & $17,452.70$ & 33.13 & 1600 & 80 \\
\hline 300 & 50068.58 & $2,780.96$ & $52,849.54$ & 176.17 & $26,179.06$ & 31.13 & 2400 & 80 \\
\hline 400 & 66758.11 & $3,707.94$ & $70,466.05$ & 176.17 & $34,905.41$ & 33.13 & 3200 & 80 \\
\hline 500 & 83447.64 & $4,634.93$ & $88,082.57$ & 176.17 & $43,631.76$ & 31.13 & 4000 & 80 \\
\hline 600 & 100137.17 & $5,561.91$ & $105,699.08$ & 176.17 & $52,358.11$ & 33.13 & 4800 & 80 \\
\hline 700 & 116826.70 & $6,488.90$ & $123,315.60$ & 176.17 & $61,084.46$ & 31.13 & 5600 & 80 \\
\hline 800 & 133516.22 & $7,415.88$ & $140,932.10$ & 176.17 & $69,810.82$ & 33.13 & 6400 & 80 \\
\hline 900 & 150205.75 & $8,342.87$ & $158,548.62$ & 176.17 & $78,537.17$ & 31.13 & 7200 & 80 \\
\hline 1000 & 166895.28 & $9,269.85$ & $176,165.13$ & 176.17 & $87,263.52$ & 31.13 & 8000 & 80 \\
\hline
\end{tabular}




\begin{tabular}{|c|c|c|c|c|c|c|}
\hline \multicolumn{7}{|c|}{$\begin{array}{l}\text { Table 15A. Near Net Shape Machining Preform Cost, B/F from } 10 \text { to } 2 \\
70 \% \text { of Material + Machining Cost Savings Applied to Preform Fabrication }\end{array}$} \\
\hline $\begin{array}{l}\text { Finished } \\
\text { Part } \\
\text { Weight, lb }\end{array}$ & $\begin{array}{l}\text { Savings } 10>2 \\
\text { B/F ratio }\end{array}$ & $\begin{array}{l}\text { Preform } \\
\text { Fabrication } \\
\text { @ } 70 \%\end{array}$ & $\begin{array}{l}\text { Preform } \\
\text { Fabrication } \\
\quad \$ / 1 b\end{array}$ & $\begin{array}{c}\text { Preform } \\
\text { Material Cost, } \\
\$\end{array}$ & $\begin{array}{l}\text { Preform Cost } \\
\$\end{array}$ & $\begin{array}{l}\text { Preform } \\
\text { Cost } \$ / 1 b\end{array}$ \\
\hline 10 & 2181.59 & 1527.11 & 76.36 & 360 & 1887.11 & 94.36 \\
\hline 20 & 4363.18 & 3054.22 & 76.36 & 720 & 3774.22 & 94.36 \\
\hline 40 & 8726.35 & 6108.45 & 76.36 & 1440 & 7548.45 & 94.36 \\
\hline 60 & 13089.53 & 9162.67 & 76.36 & 2160 & 11322.67 & 94.36 \\
\hline 80 & 17452.7 & 12216.89 & 76.36 & 2880 & 15096.89 & 94.36 \\
\hline 100 & 21815.88 & 15271.12 & 76.36 & 3600 & 18871.12 & 94.36 \\
\hline 200 & 43631.76 & 30542.23 & 76.36 & 7200 & 37742.23 & 94.36 \\
\hline 300 & 65447.64 & 45813.35 & 76.36 & 10800 & 56613.35 & 94.36 \\
\hline 400 & 87263.52 & 61084.46 & 76.36 & 14400 & 75484.46 & 94.36 \\
\hline 500 & 109079.4 & 76355.58 & 76.36 & 18000 & 94355.58 & 94.36 \\
\hline 600 & 130895.28 & 91626.70 & 76.36 & 21600 & 113226.70 & 94.36 \\
\hline 700 & 152711.16 & 106897.81 & 76.36 & 25200 & 132097.81 & 94.36 \\
\hline 800 & 174527.04 & 122168.93 & 76.36 & 28800 & 150968.93 & 94.36 \\
\hline 900 & 196342.92 & 137440.04 & 76.36 & 32400 & 169840.04 & 94.36 \\
\hline 1000 & 218158.8 & 152711.16 & 76.36 & 36000 & 188711.16 & 94.36 \\
\hline
\end{tabular}

\begin{tabular}{|c|c|c|c|c|c|c|c|c|}
\hline \multicolumn{9}{|c|}{$\begin{array}{l}\text { Table 15B. Finished Part Cost and Raw Material Reductions, B/F from } 10 \text { to } 2 \\
70 \% \text { of Material + Machining Cost Savings Applied to Preform Fabrication }\end{array}$} \\
\hline $\begin{array}{c}\text { Finished } \\
\text { Part } \\
\text { Weight, } \\
\text { lb }\end{array}$ & $\begin{array}{l}\text { Preform } \\
\text { Cost, } \$\end{array}$ & $\begin{array}{l}\text { Preform } \\
\text { Machining } \\
\text { Cost, } \$\end{array}$ & $\begin{array}{l}\text { Finished } \\
\text { Part Cost, \$ }\end{array}$ & $\begin{array}{c}\text { Cost } \\
\text { per Part } \\
\text { Lb, \$ }\end{array}$ & $\begin{array}{c}\text { Cost } \\
\text { Savings, } \$\end{array}$ & $\begin{array}{c}\text { Cost } \\
\text { Savings, } \\
\%\end{array}$ & $\begin{array}{c}\text { Titanium } \\
\text { Reduction, } \\
\text { lb }\end{array}$ & $\begin{array}{c}\text { Titanium } \\
\text { Reduction, } \\
\%\end{array}$ \\
\hline 10 & 1887.11 & 92.70 & 1979.81 & 197.98 & 654.48 & 24.84 & 80 & 80 \\
\hline 20 & 3774.22 & 185.40 & 3959.62 & 197.98 & 1308.95 & 24.84 & 160 & 80 \\
\hline 40 & 7548.45 & 370.79 & 7919.24 & 197.98 & 2617.91 & 24.84 & 320 & 80 \\
\hline 60 & 11322.67 & 556.19 & 11878.86 & 197.98 & 3926.86 & 24.84 & 480 & 80 \\
\hline 80 & 15096.89 & 741.59 & 15838.48 & 197.98 & 5235.81 & 24.84 & 640 & 80 \\
\hline 100 & 18871.12 & 926.99 & 19798.11 & 197.98 & 6544.76 & 24.84 & 800 & 80 \\
\hline 200 & 37742.23 & $1,853.97$ & $39,596.20$ & 197.98 & $13,089.53$ & 24.84 & 1600 & 80 \\
\hline 300 & 56613.35 & $2,780.96$ & $59,394.31$ & 197.98 & $19,634.29$ & 24.84 & 2400 & 80 \\
\hline 400 & 75484.46 & $3,707.94$ & $79,192.40$ & 197.98 & $26,179.06$ & 24.84 & 3200 & 80 \\
\hline 500 & 94355.58 & $4,634.93$ & $98,990.51$ & 197.98 & $32,723.82$ & 24.84 & 4000 & 80 \\
\hline 600 & 113226.70 & $5,561.91$ & $118,788.61$ & 197.98 & $39,268.58$ & 24.84 & 4800 & 80 \\
\hline 700 & 132097.81 & $6,488.90$ & $138,586.71$ & 197.98 & $45,813.35$ & 24.84 & 5600 & 80 \\
\hline 800 & 150968.93 & $7,415.88$ & $158,384.81$ & 197.98 & $52,358.11$ & 24.84 & 6400 & 80 \\
\hline 900 & 169840.04 & $8,342.87$ & $178,182.91$ & 197.98 & $58,902.88$ & 24.84 & 7200 & 80 \\
\hline 1000 & 188711.16 & $9,269.85$ & $197,981.01$ & 197.98 & $65,447.64$ & 24.84 & 8000 & 80 \\
\hline
\end{tabular}


Based on the results from Tables 6 thru 15, summarized in Figure 10, NNS machining perform costs may range from a low of $\$ 30.27$ to a high of $\$ 94.36$, depending on the cost of preform fabrication and the starting $\mathrm{B} / \mathrm{F}$ value, and still yield significant cost reduction. This preform cost includes the starting powder, powder consolidation, any secondary fabrication of PM billet, and joining or assembly operations required to form the desired preform shape. For any given preform manufacturing approach, cost models must be developed that demonstrate the preform cost target can be met. Affordable performs can be produced in a variety of ways, including using conventional ingot metallurgy materials, as long as the preform cost is sufficient to yield the desired cost reductions and the properties of the preform are sufficient for the application. In this sense, the cost savings achievable are independent of the starting material. However, in order to achieve significant energy savings, non-Kroll materials such as Armstrong powders must be used since the majority of the energy consumption occurs in the conversion process from mineral to metal.

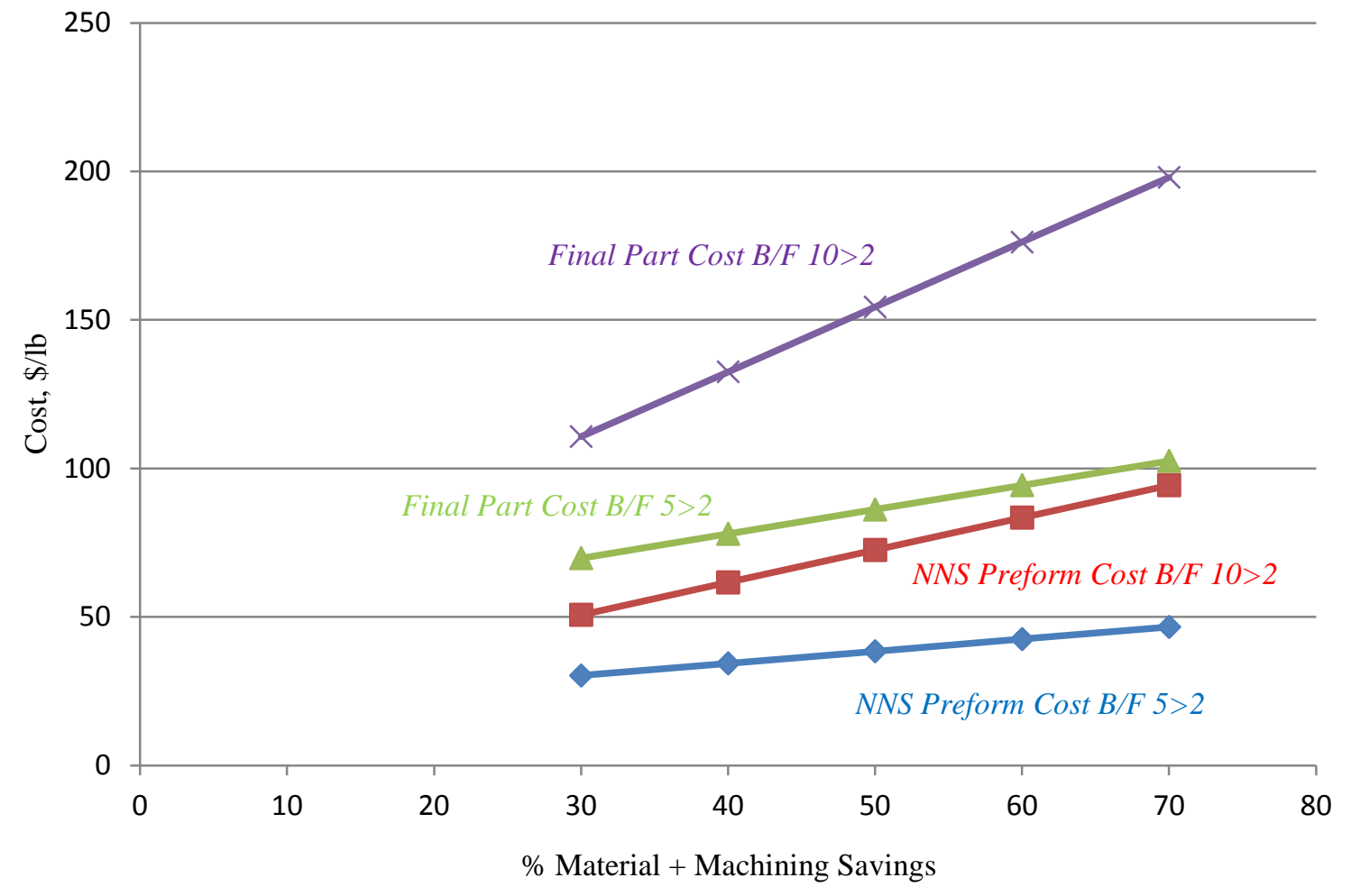

Figure 10. NNS preform and finished part cost as a function of B/F ratio.

Examination of Tables 6 through 15 shows that the preform cost in $\$ / \mathrm{lb}$ and the percentage of cost reduction possible thru NNS technology are independent of actual part weight. These two parameters, \% cost savings versus NNS preform cost in $\$ / \mathrm{lb}$, are plotted in Figure 11 for the two conventional $\mathrm{B} / \mathrm{F}$ values of 10 and 5 and a reduction in $\mathrm{B} / \mathrm{F}$ to a value of 2 with NNS technology. This graph shows that in order to achieve a minimum cost reduction of $25 \%$, the preform cost should not exceed about $\$ 42.00 / \mathrm{lb}$ if the conventional $\mathrm{B} / \mathrm{F}$ is 5 . However, if the $\mathrm{B} / \mathrm{F}$ is 10 , a preform cost can be as high as $\$ 95.00 / \mathrm{lb}$ and still allow a cost reduction of $25 \%$. Conversely, at a preform cost of $\$ 42.00 / \mathrm{lb}$, a finished part cost reduction of $25 \%$ is possible if the original $\mathrm{B} / \mathrm{F}$ is 5 , but savings grows to over $65 \%$ at the same preform cost if the conventional $\mathrm{B} / \mathrm{F}$ is 10 . This 
preform cost includes raw material and any fabrication operations required to produce the machining preform. The preform cost per pound is significantly higher than the cost of conventional titanium mill stock. However, the large reduction in raw material and the concurrent reduction in machining more than makes up for the increased material cost on a per pound basis, yielding substantial manufacturing cost reduction. In the figure, the region between the lines for $\mathrm{B} / \mathrm{F}$ of 5 and 10 may be considered to represent a practical "working zone" for titanium airframe parts. In general, the higher the starting $\mathrm{B} / \mathrm{F}$, the greater savings are possible with NNS machining performs.

It is important to realize, however, the difference between preform cost and price. The cost analysis does not include profit for the manufacturer fabricating the preform. Profit for the fabricator will increase preform price and reduce the ultimate cost reduction to the equipment manufacturer. In general, we would like to realize a minimum net $25 \%$ cost reduction via the implementation of near net shape technologies.

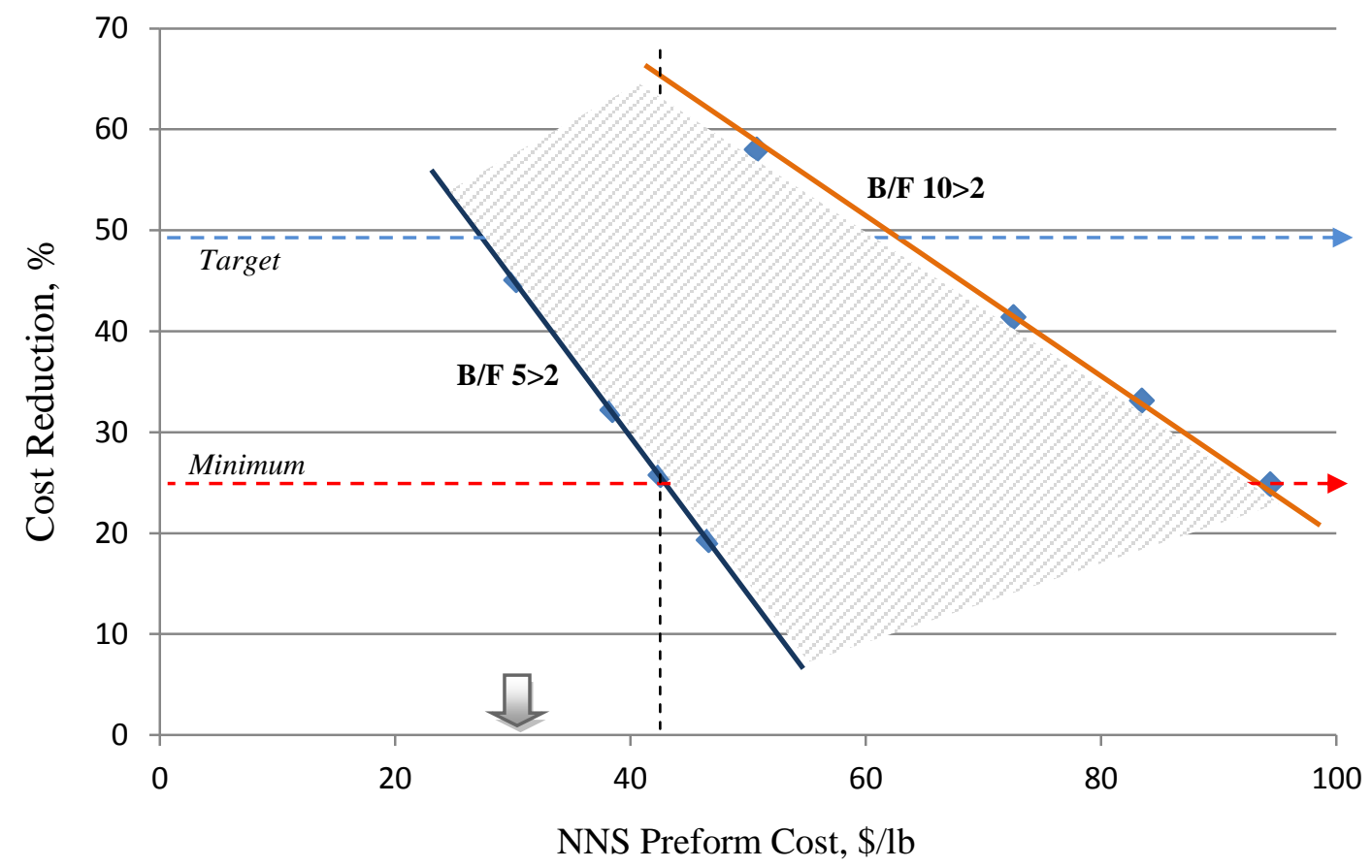

Figure 11. Relationship between NNS machining preform cost and finished part cost reduction as a function of $\mathrm{B} / \mathrm{F}$ ratio.

Manufacturing costs can be offset to some extent by recycling machining chips, which is standard practice at machining facilities that fabricate titanium components. The inclusion of some scrap in the melting of new alloy ingots also creates an energy benefit by reducing the amount of fresh titanium sponge required from the Kroll process, as discussed in the previous section. To estimate the impact of recycling on preform cost, we have assumed a current value of $\$ 3.00 / \mathrm{lb}$ for recycled chips. This value will fluctuate with the market, depending on the price of titanium. 
Combined material and machining costs were presented in Table 4 as a function of part weight and $\mathrm{B} / \mathrm{F}$ ratio. These values are presented again in Table 16, with the recycling credit for machine chips factored in. The higher the $\mathrm{B} / \mathrm{F}$ ratio, the greater the credit for a given part weight, since the quantity of chips available for recycling is a function of the B/F. For a B/F of 10 , chip recycling reduces material + machining costs by $10.3 \%$. This credit is reduced to $9.5 \%$ for a $\mathrm{B} / \mathrm{F}$ of 5 , and to $6.6 \%$ for our target $\mathrm{B} / \mathrm{F}$ of 2 .

\begin{tabular}{cccc}
\hline $\begin{array}{c}\text { Table 16. Finished Part Material + Machining Costs as a f(B/F) Ratio, } \$ \\
\text { Includes Credit for Recycled Machining Chips @ } \$ 3.00 / \text { lb }\end{array}$ \\
\hline Part Wt, lbs & 10 & B/F & 2 \\
10 & $\$ 2,364.27$ & $\$ 1,150.70$ & $\$ 422.82$ \\
20 & $\$ 4,728.54$ & $\$ 2,301.41$ & $\$ 845.64$ \\
40 & $\$ 9,457.09$ & $\$ 4,602.82$ & $\$ 1,691.28$ \\
60 & $\$ 14,185.63$ & $\$ 6,904.22$ & $\$ 2,536.92$ \\
80 & $\$ 18,914.18$ & $\$ 9,205.63$ & $\$ 3,382.56$ \\
100 & $\$ 23,642.72$ & $\$ 11,507.04$ & $\$ 4,228.20$ \\
200 & $\$ 47,285.44$ & $\$ 23,014.08$ & $\$ 8,456.41$ \\
300 & $\$ 70,928.16$ & $\$ 34,521.12$ & $\$ 12,684.61$ \\
400 & $\$ 94,570.89$ & $\$ 46,028.16$ & $\$ 16,912.82$ \\
500 & $\$ 118,213.61$ & $\$ 57,535.20$ & $\$ 21,141.02$ \\
600 & $\$ 141,856.33$ & $\$ 69,042.24$ & $\$ 25,369.22$ \\
700 & $\$ 165,499.05$ & $\$ 80,549.28$ & $\$ 29,597.43$ \\
800 & $\$ 189,141.77$ & $\$ 92,056.32$ & $\$ 33,825.63$ \\
900 & $\$ 212,784.49$ & $\$ 103,563.36$ & $\$ 38,053.84$ \\
1,000 & $\$ 236,427.21$ & $\$ 15,070.40$ & $\$ 42,282.04$ \\
\hline
\end{tabular}

Because the recycling credit is greater at higher $\mathrm{B} / \mathrm{F}$, the savings achieved in reducing $\mathrm{B} / \mathrm{F}$ is decreased. As an example, without chip recycling, the material + machining cost savings possible in reducing $\mathrm{B} / \mathrm{F}$ from 10 to 2 is $\$ 2,181.59$ for a $10 \mathrm{lb}$. part (from Table 4 ). Applying a chip recycling credit of $\$ 3.00 / \mathrm{lb}$ yields a credit of $\$ 270.00$ at a $\mathrm{B} / \mathrm{F}$ of 10 , and a credit of only $\$ 30.00$ at a $\mathrm{B} / \mathrm{F}$ of 2 . The material + machining cost reduction achieved with the chip credit is $\$ 1,941.59$, a reduction of $11 \%$ compared to the cost reduction estimated without applying the chip credit.

In the analyses from Tables 6 thru 15, we calculated preform costs and cost savings achieved thru reduced $\mathrm{B} / \mathrm{F}$ for various preform fabrication cost scenarios. We estimated preform fabrication costs as a percentage of the material + machining cost savings, ranging from 30 to $70 \%$. Since the preform fabrication cost is unchanged by chip recycling, the preform cost on a per pound basis is also unchanged. However, the part savings possible thru reduced $\mathrm{B} / \mathrm{F}$ is impacted, since chip recycling effectively reduces the total material + machining savings possible by reducing net material cost. This effect is illustrated in Figure 12, which plots the finished part cost reduction as a function of preform cost as shown previously in Figure 11. The 
effect of recycling is a function of $\mathrm{B} / \mathrm{F}$, since the higher $\mathrm{B} / \mathrm{F}$ ratio offers more chips for recycling and hence a relatively higher reduction in the material + machining savings possible.

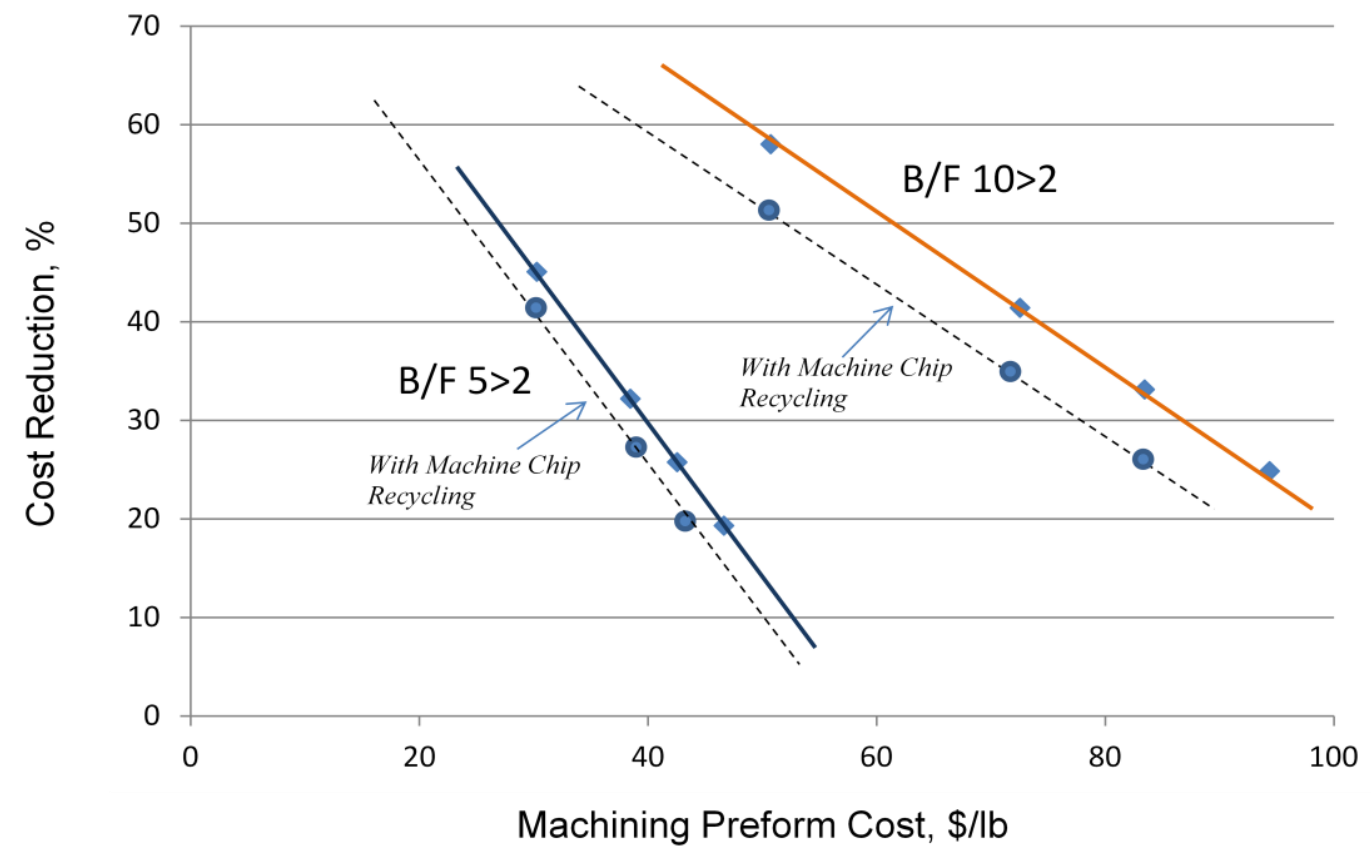

Figure 12. Relationship between NNS machining preform cost and finished part cost reduction as a function of $\mathrm{B} / \mathrm{F}$ ratio when the benefits of chip recycling are factored into cost reduction.

\section{Task 2: Identify Opportunities}

The objectives of this task were to identify opportunities for NNS titanium products in commercial aircraft to achieve significant improvements in energy efficiency and affordability. Airframe structure for the 787 was surveyed to define different part types or families suitable for the NNS approach based on size and geometry. Then, for each part type, manufacturing strategies were defined using NNS performs. These strategies were then analyzed to determine the most promising approach for each part type.

The total number of individual titanium parts identified in the survey is 4,729 , as shown in the distribution charts of Figure 13. Of these parts, sheet metal parts (1,989 parts, $42.4 \%$ of the total) and parts machined from plate stock (1,594 parts, 34\% of the total) comprise the largest fraction by part count. However, sheet metal parts represent only a small fraction of the titanium by weight, only $1.5 \%$ of the total, while parts machined from plate, forgings, extrusion, and rolled bar account for over $98 \%$ of the total weight of titanium and 115, 139 individual parts. This analysis shows that parts fabricated from plate stock and from long product (extrusion and rolled bar) account for the majority of parts (59.9 and $22.6 \%$ respectively). Based on this result, our analysis focused on the part configurations typically fabricated from these titanium mill product forms. Examples of parts fabricated from plate stock and long product are shown in 
Figure 14. Parts fabricated from plate stock are typically flat stiffened panels, while parts machined from long product are beams with various details including flanges and stiffener patterns. These part configurations appear to be amenable to the NNS approach, where the preform is built up from regular geometric mill product forms using various joining techniques.

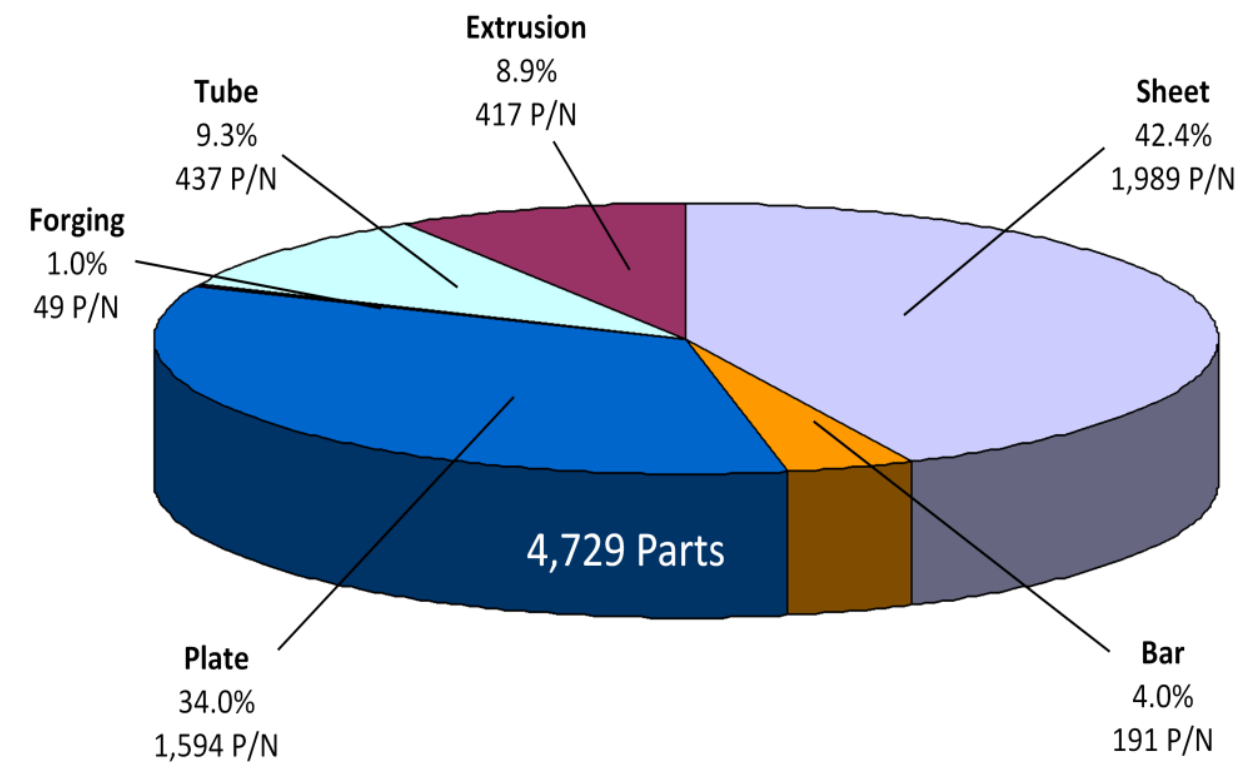

Titanium Part Distribution by Number of Parts

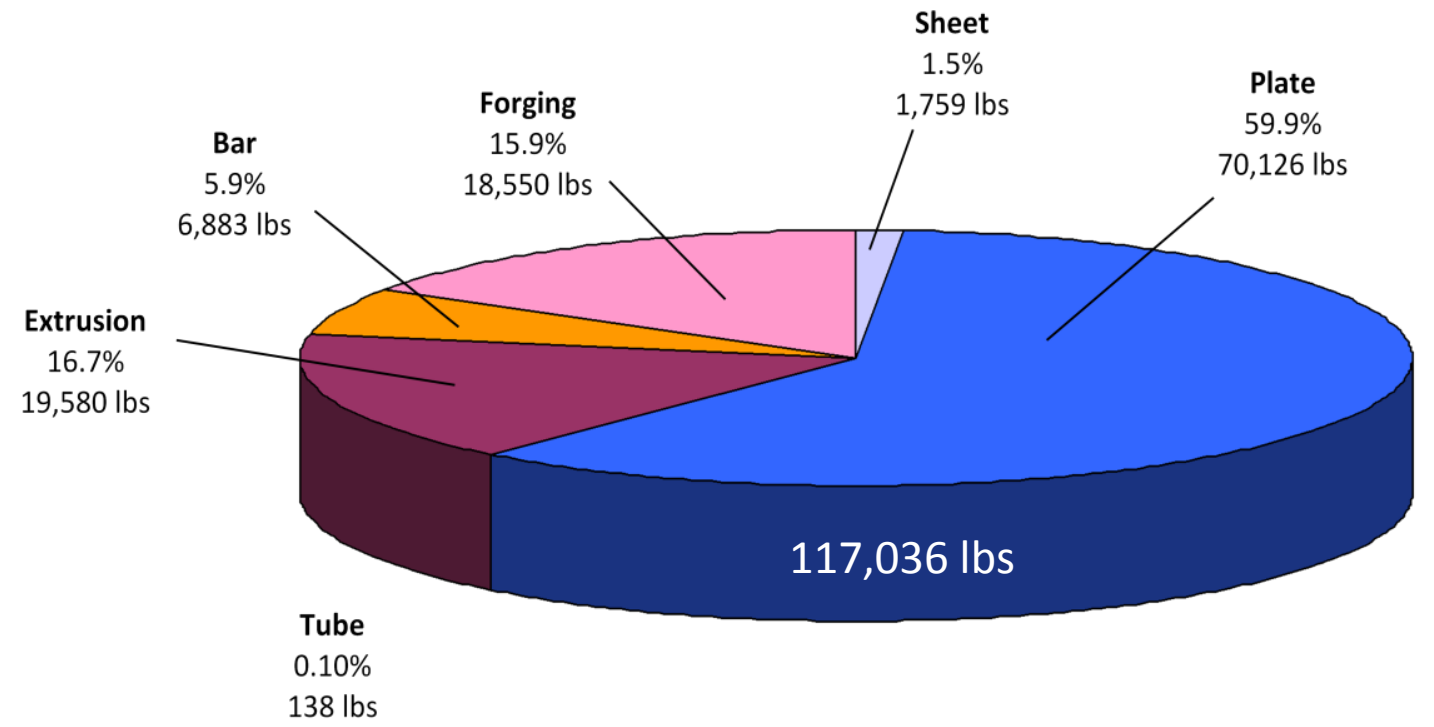

\section{Part Distribution by Weight}

Figure 13. Distribution of titanium parts as a function of material product form by number of parts and total weight of parts. 

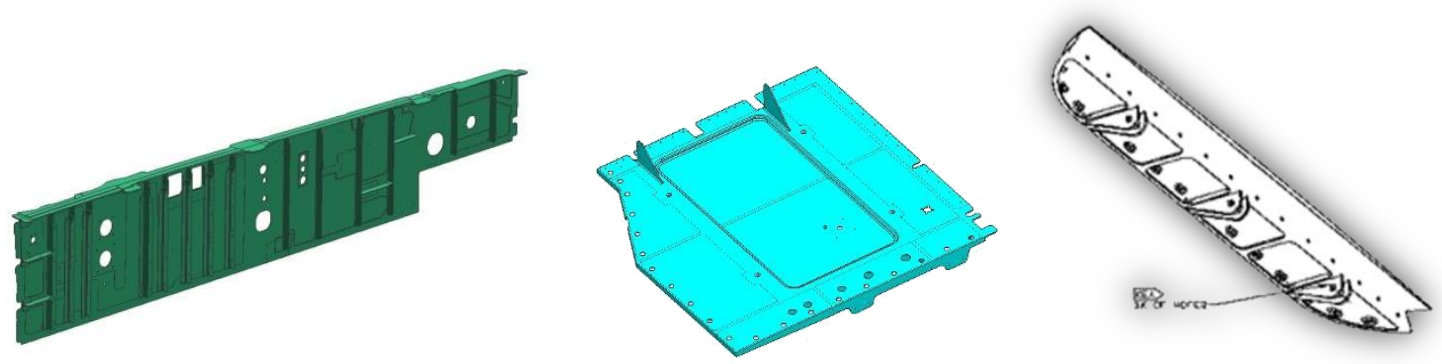

Flat, Planar Parts Machined from Plate Stock
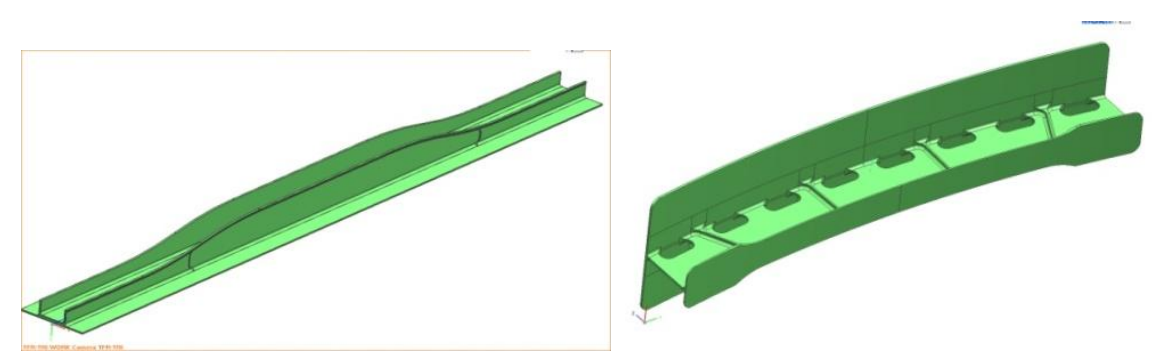

Beams Machined from Extrusion, Bar Stock

Figure 14. Major Titanium Part Types for NNS Preform Technology

We examined various approaches to producing standard mill products from powder, such as plate, bar, and extrusion, which represent the building blocks for the preforms. The specific approach for a given mill product form depends on the type of powder being used to produce it. For three different candidate low-cost powders: Armstrong pre-alloyed powder produced by ITP, pure titanium powder produced using the Cambridge process by Metalysis, and pure titanium powder produced from Kroll sponge fines and processed by ADMA Products, the various approaches to mill product fabrication for plate, hot-rolled bar, and extrusions respectively are listed below. Each processing option is referred to as a processing "track". Note that only the critical processing steps are indicated, and secondary unit operations such as billet trimming are left out for clarity. Those tracks that utilize pure titanium powders would use what is referred to as the "blended elemental" approach to alloy formation, in which titanium powder is blended with aluminum-vanadium master alloy powder (assuming the desired alloy is the standard Ti$6 \mathrm{Al}-4 \mathrm{~V}$ alloy) and then cold isostatic pressed and sintered to form a billet (CIP + Sinter). During sintering at high temperature, the alloying elements diffuse together forming the desired alloy chemistry. Thus, the sintering step is required when pure titanium powders are being used. Prealloyed powders may be consolidated into billet form by hot isostatic pressing (HIP). Billets for extrusion typically have tight dimensional requirements, and billets are machined prior to extrusion. 
Conventional Ingot Metallurgy Approach to Plate Stock:

Kroll Ingot > Ingot Breakdown > Hot Roll > Heat Treat

Low Cost Powder Metallurgy Approach to Plate Stock:

Processing Track P1 (Armstrong Pre-alloyed Powder):

Attrit $>\mathrm{CIP}>\mathrm{Can}>\mathrm{HIP}>\mathrm{Hot}$ Roll $>$ Heat Treat

Processing Track P2 (Armstrong Pre-alloyed Powder):

Attrit $>$ CIP $>$ Sinter $>$ Hot Roll $>$ Heat Treat

Processing Track P3 (Cambridge CP Ti Granules):

Attrit $>$ Blend $>$ CIP $>$ Sinter $>$ Hot Roll $>$ Heat Treat

Processing Track P5 (Kroll CP Ti Sponge Fines):

Blend > CIP > Sinter > Hot Roll > Heat Treat

Conventional Ingot Metallurgy Approach to Bar Stock:

Kroll Ingot > Ingot Breakdown > Hot Work > Heat Treat

Low-cost Powder Metallurgy Approach to Bar Stock:

Process Track B3 (Armstrong Pre-alloyed Powder)

Attrit $>$ CIP $>$ Can $>$ HIP $>$ Hot Work $>$ Heat Treat

Process Track B4 (Armstrong Pre-Alloyed Powder)

Attrit > CIP > Sinter > Hot Work > Heat Treat

Process Track B5 (Cambridge CP Ti Granules):

Attrit $>$ Blend $>C I P>$ Sinter $>$ Hot Work $>$ Heat Treat

Process Track B6 (Kroll CP Ti Sponge Fines):

Blend $>$ CIP $>$ Sinter $>$ Hot Work $>$ Heat Treat

Conventional Ingot Metallurgy Approach to Extrusion:

Kroll Ingot > Ingot Breakdown > Machine > Extrude > Heat Treat

Low-cost Powder Metallurgy Approach to Extrusion:

Process Track E2 (Armstrong Pre-alloyed Powder)

Attrit $>$ CIP $>$ Can $>$ HIP $>$ Machine $>$ Extrude $>$ Heat Treat

Process Track E3 (Armstrong Pre-Alloyed Powder)

Attrit $>$ CIP $>$ Sinter $>$ Machine $>$ Extrude $>$ Heat Treat

Process Track E4 (Cambridge CP Ti Granules):

Attrit $>$ Blend $>C I P>$ Sinter $>$ Machine $>$ Extrude $>$ Heat Treat

Process Track E5 (Kroll CP Ti Sponge Fines):

Blend $>$ CIP > Sinter > Machine > Extrude $>$ Heat Treat

Examples of powder metallurgy mill products are shown in Figure 15. Pieces of Ti-6Al-4V plate and bar stock are shown, produced from hydride/dehydride (HDH) powders and blended elemental (BE) powders. HDH powder is produced by introducing hydrogen into titanium to embrittle the material, then crushing the material into powder, and vacuum annealing to remove the hydrogen from the powder. BE material is produced by blending pure titanium powder, typically in the form of sponge fines, together with Al-V master alloy powder, cold pressing the blend into a compact, and sintering to diffuse the chemical species together and form the alloy 
and densify the compact. Both $\mathrm{HDH}$ and $\mathrm{BE}$ approaches are commercially available technologies. These materials were used for the technical feasibility studies in Task 4.

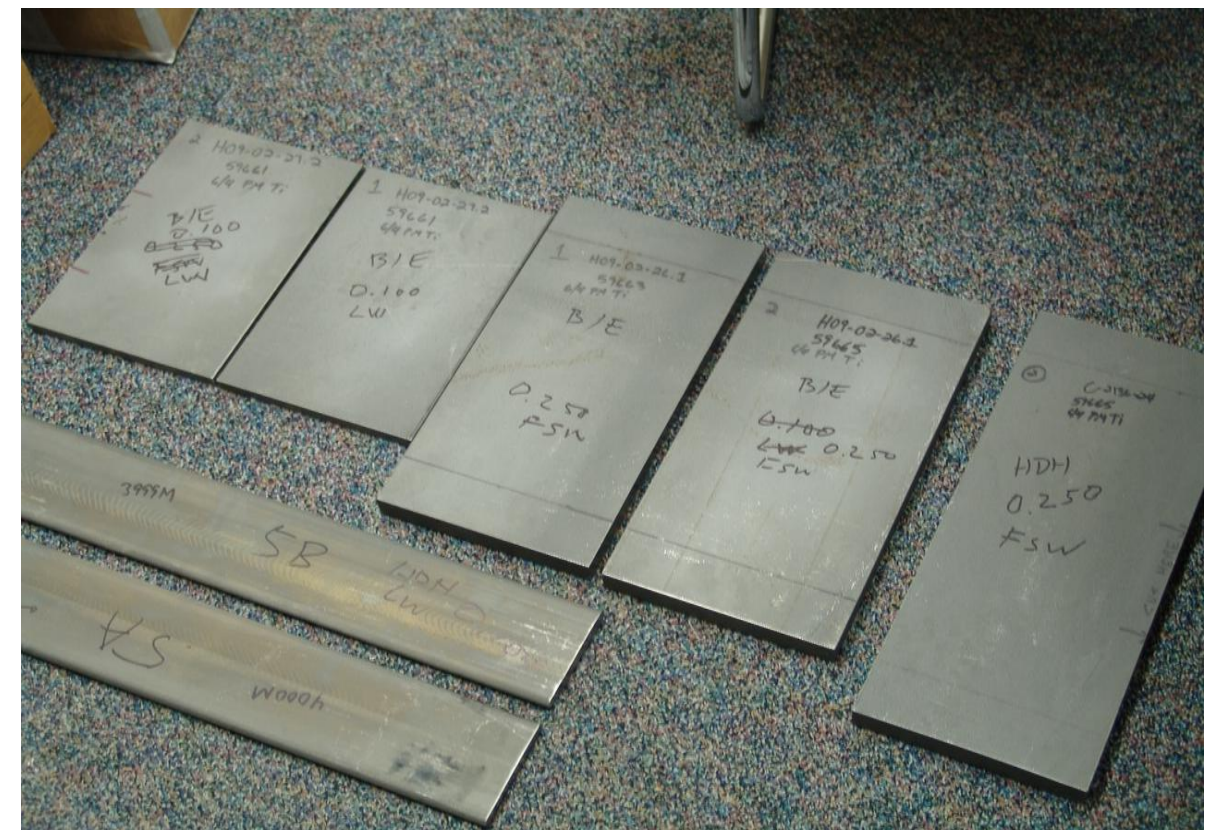

Figure 15. $\mathrm{HDH}$ and BE powder metallurgy plate and bar stock used for joining/assembly trials in technical feasibility studies.

NNS machining preforms for parts fabricated from plate stock could be assembled using plate and bar stock, while multiple pieces of bar and/or extrusion could be used to produce preforms for parts typically machined from long product (bar and extrusion). Based on the benefits analysis performed in Task 2, the conversion energy (from mineral to metal powder) dominates the energy consumed for both conventional machining and the NNS approach. Energy consumption for other unit operations within a given processing track are small compared to the conversion energy. Thus, the benefits analysis assumes a generic NNS preform having a target $\mathrm{B} / \mathrm{F}$ value of 2 , and benefits were estimated irrespective of the specific process track used to convert powder into preform. Similarly, cost reductions associated with NNS preforms are dominated by the reduced material and machining requirements for part fabrication, again irrespective of the specific process track used to convert powder to preform. Based on the results of the benefits analysis and our improved understanding of the contributions of the various processing steps to energy consumption and costs, we chose not to analyze each candidate process track in detail.

\section{Task 3: Evaluate Approaches to NNS Products}

The objectives of this task were to survey potential approaches to processing of low-cost titanium alloy powders and particulates produced by innovative energy-efficient methods such as Armstrong and FFC Cambridge processes into near net shaped products. Key issues include powder consolidation, production of intermediate geometric forms, and joining/assembly 
techniques to produce the optimum preform design for a given part type or family. This survey was to address important technical issues including energy consumption, yields of useful material and yield losses, shape control during densification, and cost of finished parts relative to conventional machinings. As discussed in the previous section, energy and cost benefits are dominated by the conversion process and large reduction in material and machining requirements, respectively, rather than specific unit operations used to fabricate machining performs. Thus, detailed analysis of any individual processing sequence is not necessary for an initial quantification of benefits.

Other technical issues, such as yield losses and shape control during powder consolidation are important, because they impact the amount of material needed for NNS processing. Our original plan was to perform this task by processing Armstrong and Cambridge process materials to quantify yields and their impact on energy consumption and part costs. However, due to delays in bringing the production plant online, ITP was not able to supply the powder needed for this task. A small amount of Cambridge process material was provided by Metalysis, and characterization of this material (described in the Task 4 discussion) identified a number of processing issues that made further processing of this material impractical.

Key to efficient consolidation is shape control during densification. A baseline yield analysis is available for HDH powders consolidated by HIP. A powder consolidation process is required that optimizes the yield of useful material to minimize material cost by provided a fully dense geometric shape as close as possible to that of the desired final component. Poor shape control would require the use of more material than needed, and additional machining to achieve the finished part configuration. The yield analysis presented in Figure 16 is for cylindrical billets consolidated from HDH powder having a 50\% packing density in the steel HIP can. A series of billets were produced at Bodycote, using their standard HIP cycle for titanium powder. As-HIP billets were scanned with an ATOS light system, and a 3D model of the billet was generated. The model was then queried to determine the largest cylindrical billet that could be machined from the as-HIP billet. Further processing, including bar rolling and extrusion, requires a turned cylinder with the steel HIP can removed. The greater the irregular geometry of the HIP billet, the higher the yield losses in turning down to a cylinder. This analysis shows that the average yield of useful material for HIP HDH powder is on the order of $86.8 \%$. Thus, an excess of powder of about $13 \%$ is required to yield a desired billet diameter, and this additional material increases the billet cost on a per pound basis. Because Armstrong powder has a packing fraction on the order of $6 \%$, powder must be processed to increase packing fraction to maximize billet yields. A powder attrition process may be used, or powder could be cold compacted prior to HIP. This step will be critical to achieving affordable billets made from Armstrong powder. Examples of cylindrical HIP billets produced from HDH powders, and turned billets with the steel HIP can removed, are shown in Figure 17. 


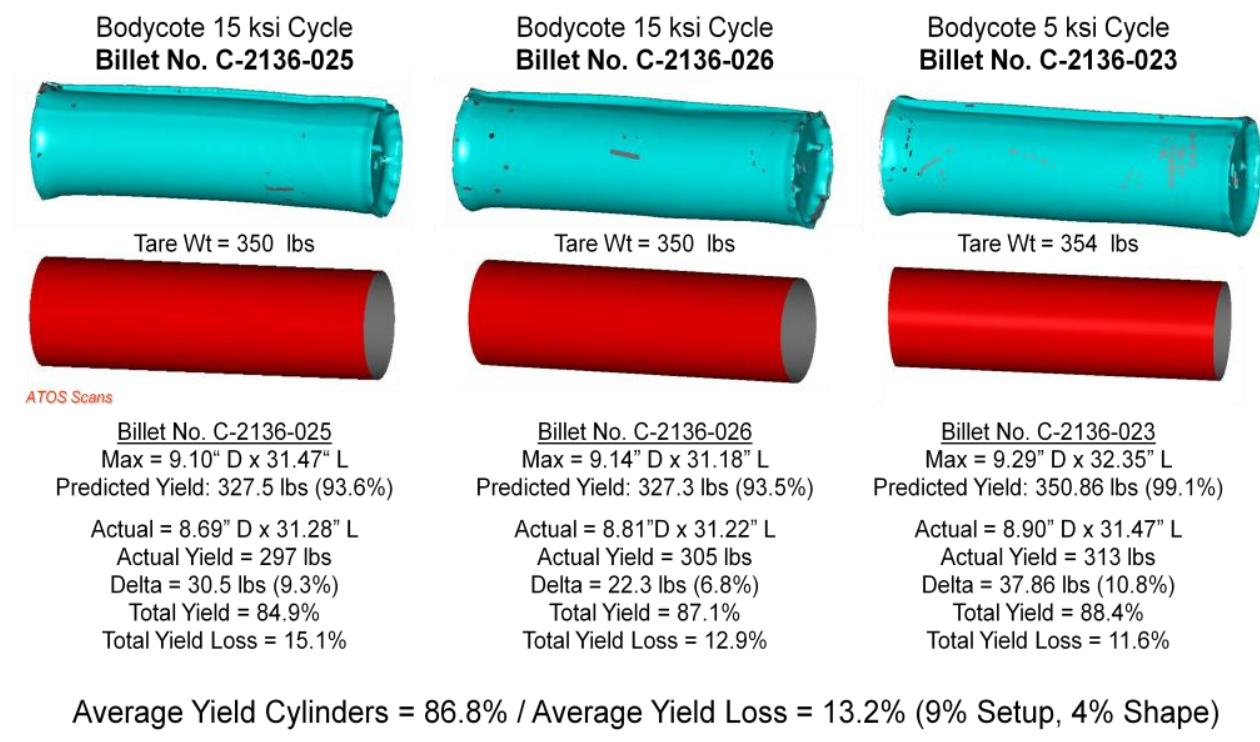

Figure 16. Yield analysis for HDH titanium powder HIP cylindrical billets.
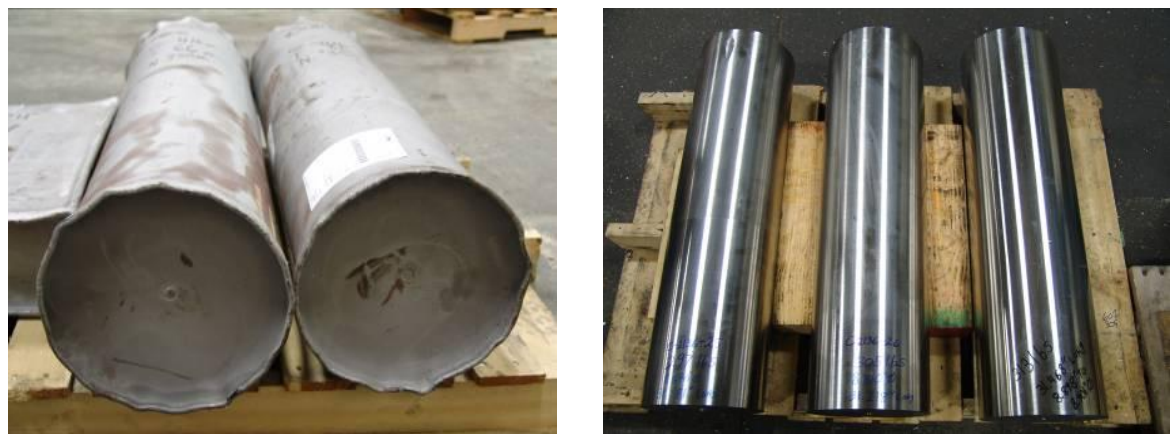

Figure 17. Examples of HDH titanium HIP billets and cylindrical billets after can removal.

\section{Task 4: Determine Technical Feasibility}

The plan for this task included fabrication of conventional mill products from Armstrong Ti-6Al$4 \mathrm{~V}$ powder, demonstrating assembly of the various mill product building blocks into a NNS preform, and characterizing powder, mill product, and NNS preform. However, due to delays in bringing the Armstrong powder production plant online, we were unable to obtain the powder needed for this task. Instead, we utilized powder metallurgy HDH and BE Ti-6Al-4V plate and bar stock that were available from other Boeing internal work. The HDH billets for this material were produced by Bodycote North American HIP, and BE billets were fabricated by ADMA Products. Plate rolling was performed at Niagara Specialty Metals (HDH and BE plate), and rectangular bar was hot rolled at Dunkirk Steel. Materials were processed under an internal Boeing project, and sufficient quantities for our technical feasibility studies were procured by the project. Examples of these materials were shown in Figure 15. The objective of the feasibility study was to demonstrate that NNS preforms could be assembled from PM mill product building 
blocks using advanced joining methods for titanium that exhibited material behavior sufficient for structural applications.

A small amount of Cambridge titanium was procured and characterized. Material was supplied in the form of hollow discs cut in half as illustrated in Figures 18 and 19. The disc format facilitates fabrication of the $\mathrm{TiO}_{2}$ preforms and the conversion reaction. The cross-section photomicrograph shows the porous nature of the converted product.

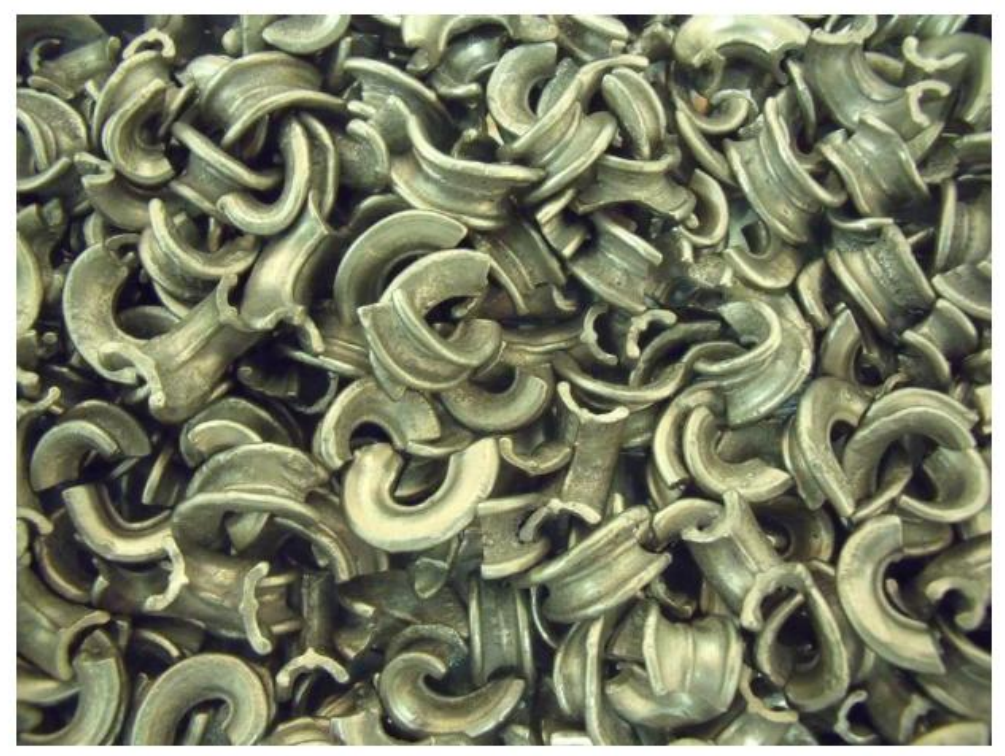

Figure 18. Cambridge process titanium from Metalysis Ltd, Rotherham, UK

Cambridge process titanium was supplied in the form of hollow discs cut in half, referred to a "saddles".
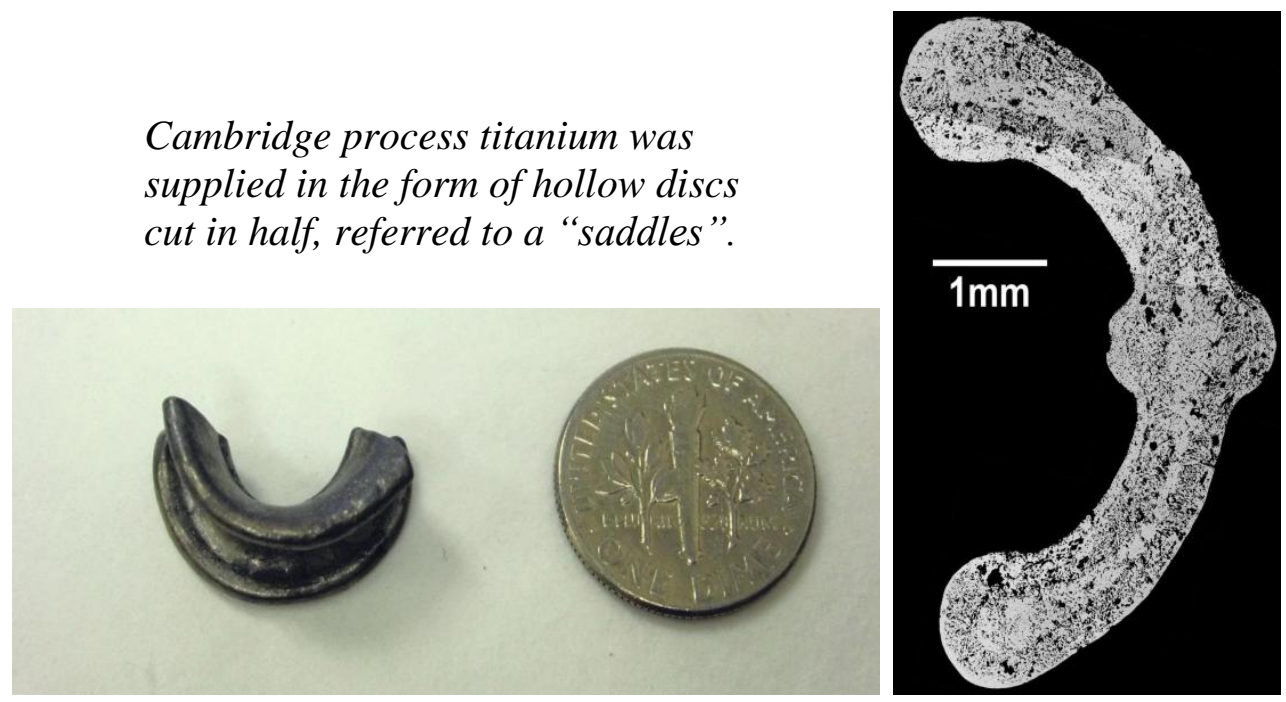

Figure 19. Cambridge process titanium. 
A chemical analysis of the material (Figure 20) indicates a high $\mathrm{Ca}$ content, likely due to entrapment of the $\mathrm{CaCl}_{3}$ salt used as the electrolyte in the conversion process. The oxygen content also exceeds that of commercial grades of titanium. The high oxygen content could be due to incomplete conversion of the $\mathrm{TiO}_{2}$, or post-process contamination due to atmospheric exposure. Energy dispersive x-ray analysis also shows carbon contamination from the graphite electrodes used in the electrochemical processing.

\begin{tabular}{|c|c|c|c|c|c|c|c|c|c|}
\hline & Oxygen & $\underline{\text { Nitrogen }}$ & Carbon & $\underline{\text { Iron }}$ & Aluminum & $\underline{\text { Silicon }}$ & Manganese & Calcium & 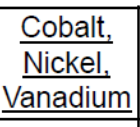 \\
\hline Metalysis & $\%$ & \% & \% & $\underline{\%}$ & \% & $\underline{\%}$ & $\underline{\%}$ & \% & $\%$ \\
\hline Saddles & $\begin{array}{c}0.384+/- \\
0.143^{*} \\
\end{array}$ & $\begin{array}{c}.056+/- \\
0.011^{*} \\
\end{array}$ & 0.051 & 0.085 & 0.0050 & 0.036 & 0.039 & 0.45 & $<0.0005$ \\
\hline \multicolumn{10}{|c|}{ ASTM B265: Grades 1-4 } \\
\hline Grade 1 & 0.18 & 0.03 & 0.08 & 0.2 & -- & -- & N/A & N/A & -- \\
\hline Grade 2 & 0.25 & 0.03 & 0.08 & 0.3 & - & -- & N/A & N/A & -- \\
\hline Grade 3 & 0.35 & 0.05 & 0.08 & 0.3 & - & -- & $\mathrm{N} / \mathrm{A}$ & $\mathrm{N} / \mathrm{A}$ & - \\
\hline Grade 4 & 0.40 & 0.05 & 0.08 & 0.5 & - & -- & $\mathrm{N} / \mathrm{A}$ & $\mathrm{N} / \mathrm{A}$ & - \\
\hline
\end{tabular}

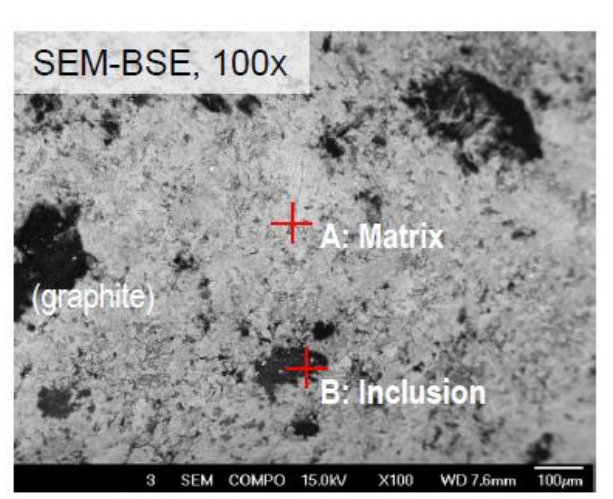

\section{B: Inclusion}

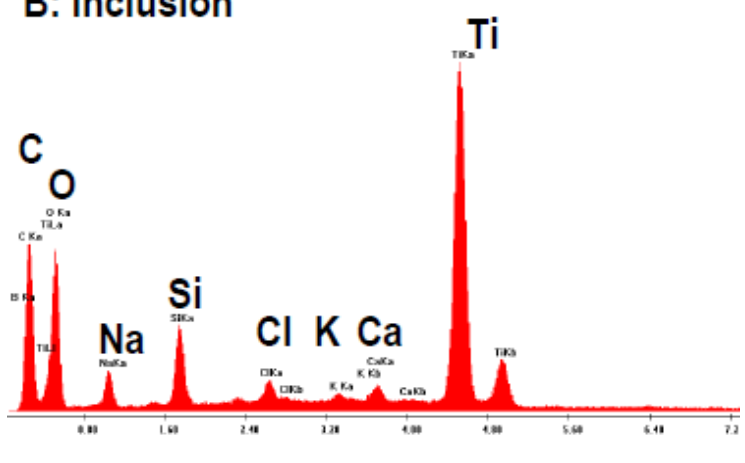

Figure 20. Chemical analysis of pure titanium produced by the Cambridge process.

Several attempts were made to produce a small billet by vacuum hot pressing of Cambridge material. Vacuum hot pressing at $950^{\circ} \mathrm{C}$ for 1 hour at $21 \mathrm{MPa}$ pressure failed to densify the material, as shown in Figure 21. A second attempt at $1100^{\circ} \mathrm{C}$ and 2 hours at $21 \mathrm{MPa}$ pressure achieved better results, producing a small 1.5 -inch diameter cylindrical billet.
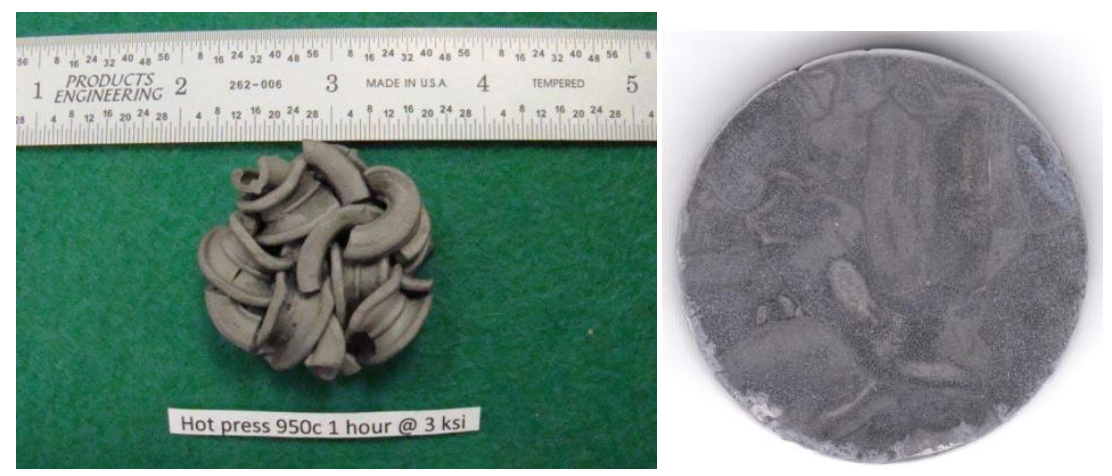

Figure 21. Cambridge titanium after consolidation by vacuum hot pressing. 
Characterization of Cambridge material supplied by Metalysis indicates that additional process development is needed to optimize product chemistry to meet commercial standards. Based on the results of this analysis, and the lack of sufficient material, no further work was done with Cambridge material in this project.

\section{Laser Joining}

We evaluated laser welding (LW) as a method of joining mill product building blocks and forming a NNS preform. For LW, HDH and BE Ti-6Al-4V plate and extrusion stock were machined to 0.100 inch thickness to enable us to use our existing process development setup. Bead-on-plate laser welds were produced at welding speeds ranging from $20 \mathrm{in} / \mathrm{min}$ to 160 in/min to establish optimum process parameters. The weld power was varied from 1000 to 4000W. Typical welds are illustrated in Figure 22 below.
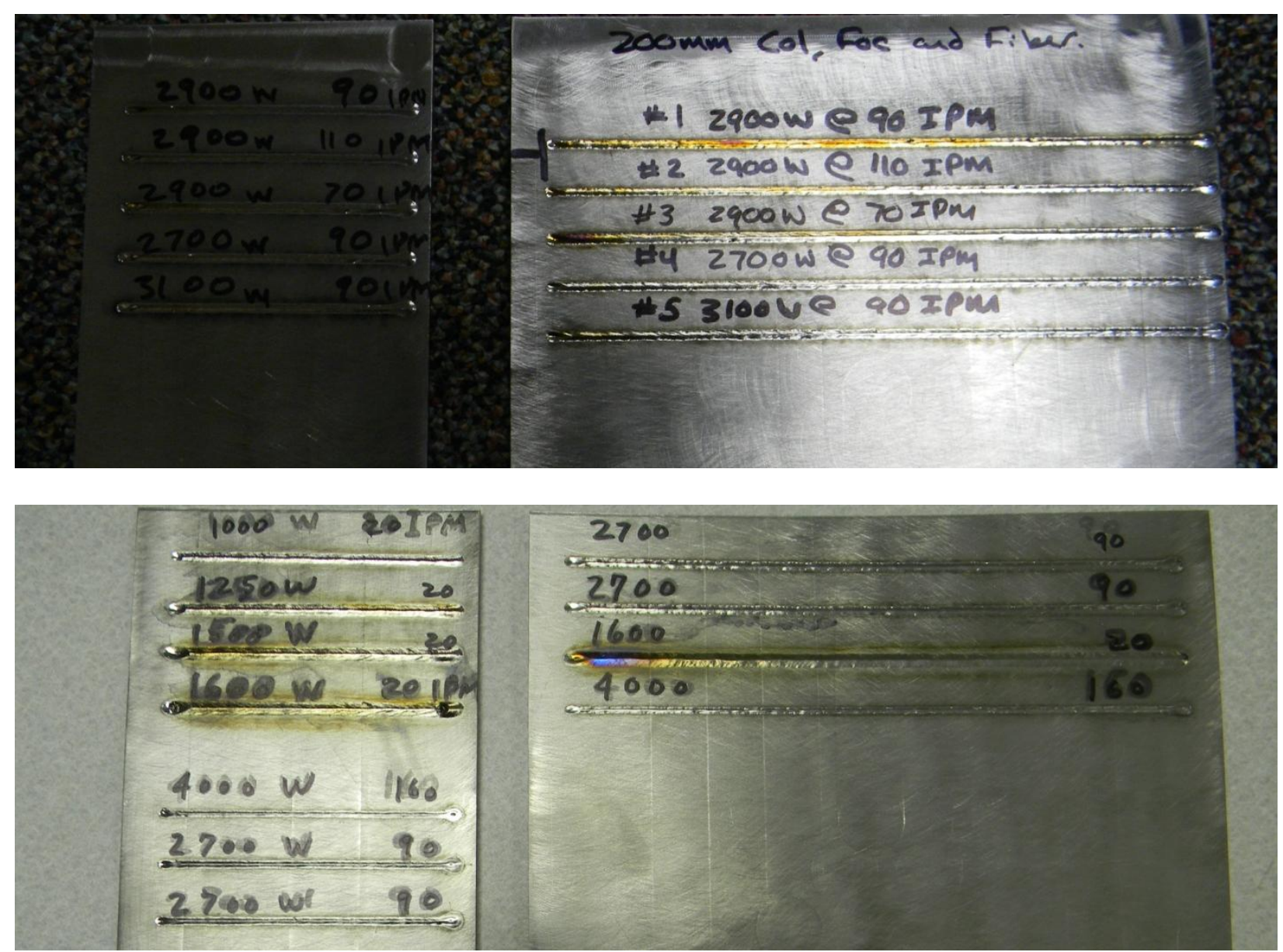

Figure 22. Laser welds on PM Ti-6Al-4V plate and extrusion samples.

Welds were examined by x-ray non-destructive inspection and optical microscopy of weld cross sections. The x-ray photographs in Figure 23 for BE material and Figure 24 for HDH material show that significant porosity is present in the weld zone over the range of weld conditions, and 
the pores appear to be associated with the weld zone - base metal interface for both BE and HDH materials. Porosity is also evident in the cross-sectional photomicrographs shown in Figures 25 and 26. It appears that there is chemical contamination in the material, which heating or melting during welding releases as a gas that creates the porosity. It is possible that the porosity issue can be alleviated by going to very high power levels, but further process development is needed beyond the normal range of parameters for titanium welding.
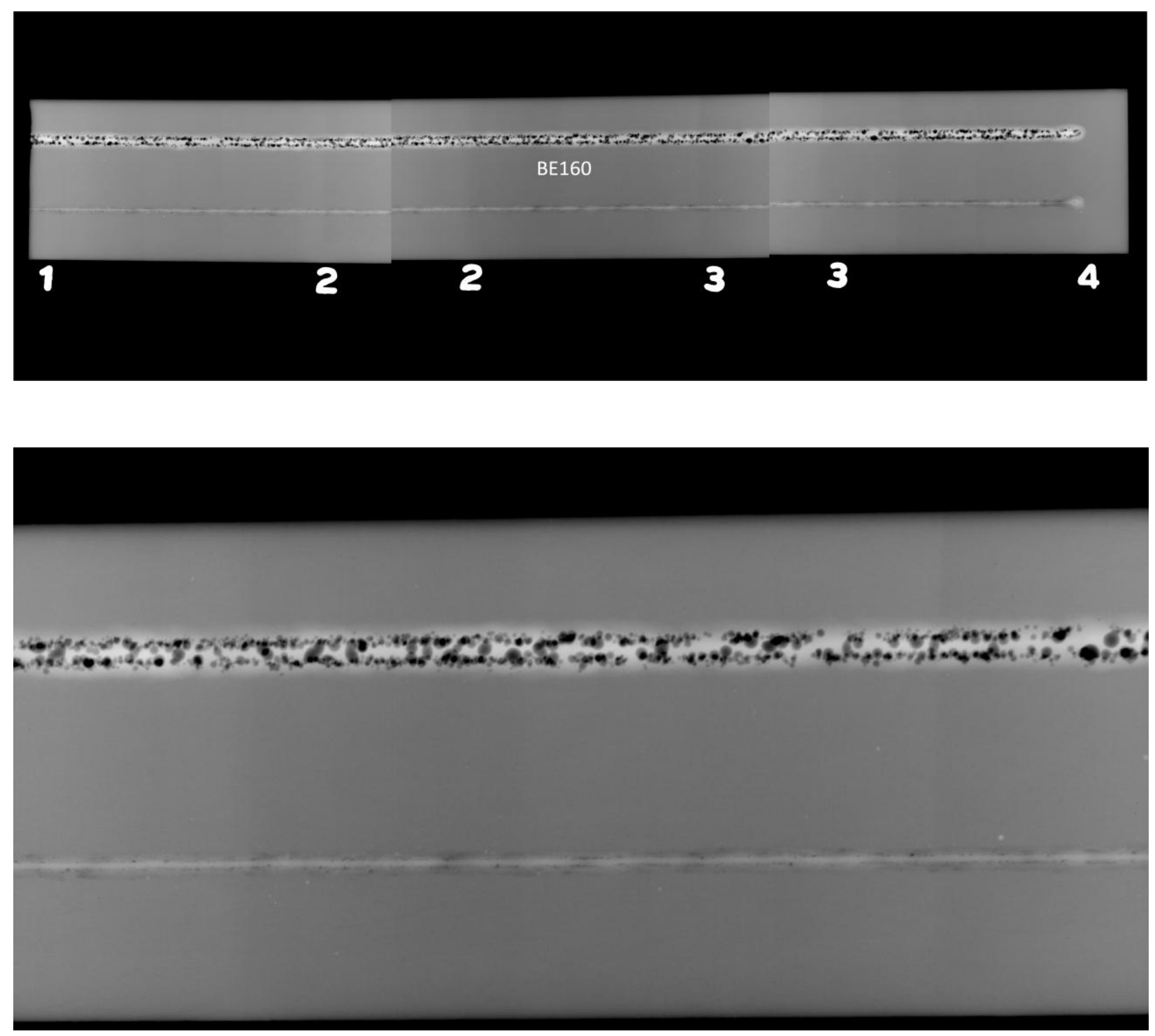

Figure 23. X-ray photographs of laser welds in BE Ti-6Al-4V mill stock produced at 20 and $160 \mathrm{in} / \mathrm{min}$ linear speed. 


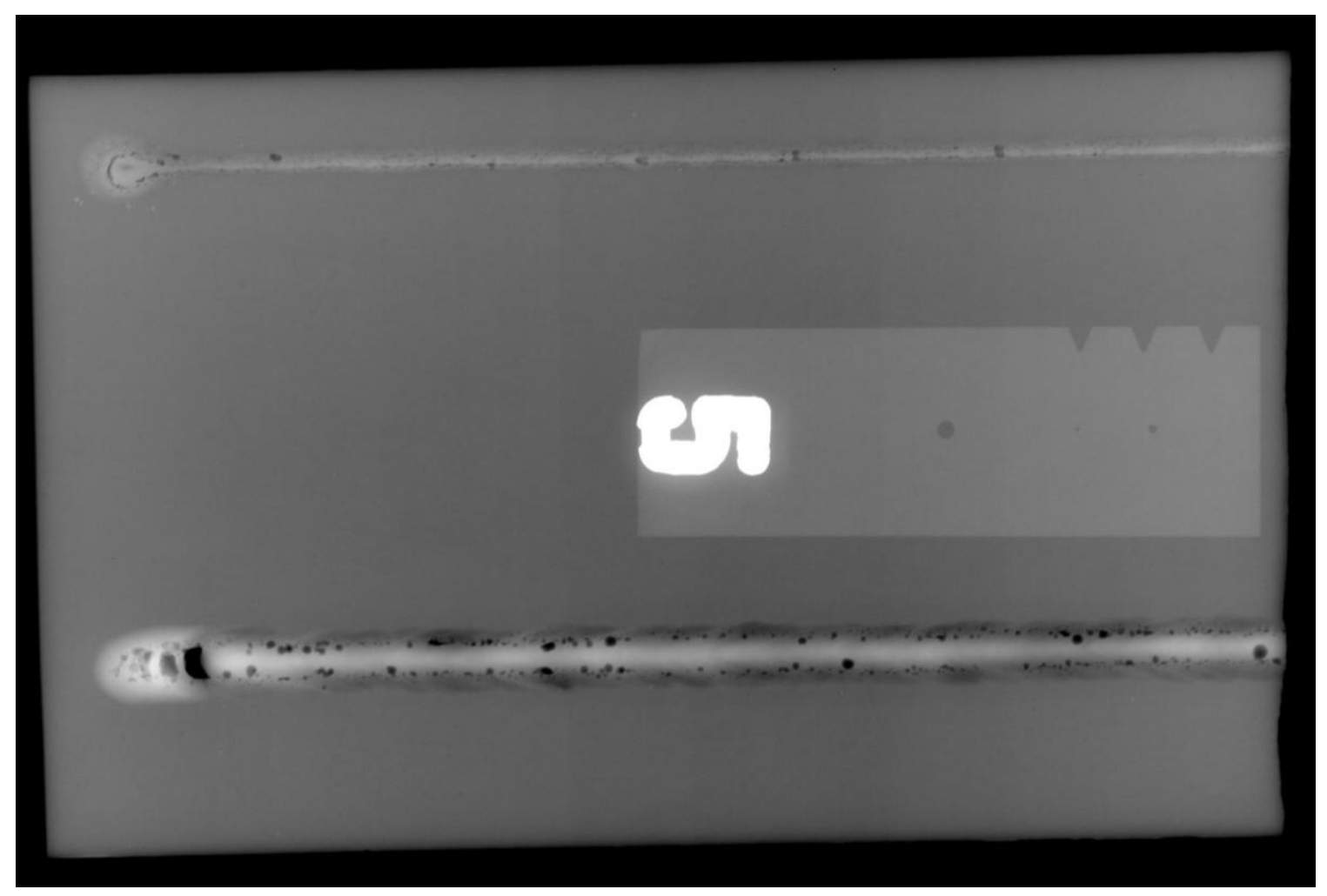

Figure 24. X-ray photographs of laser welds in HDH Ti-6Al-4V mill stock produced at 20 and $160 \mathrm{in} / \mathrm{min}$ linear speed. 

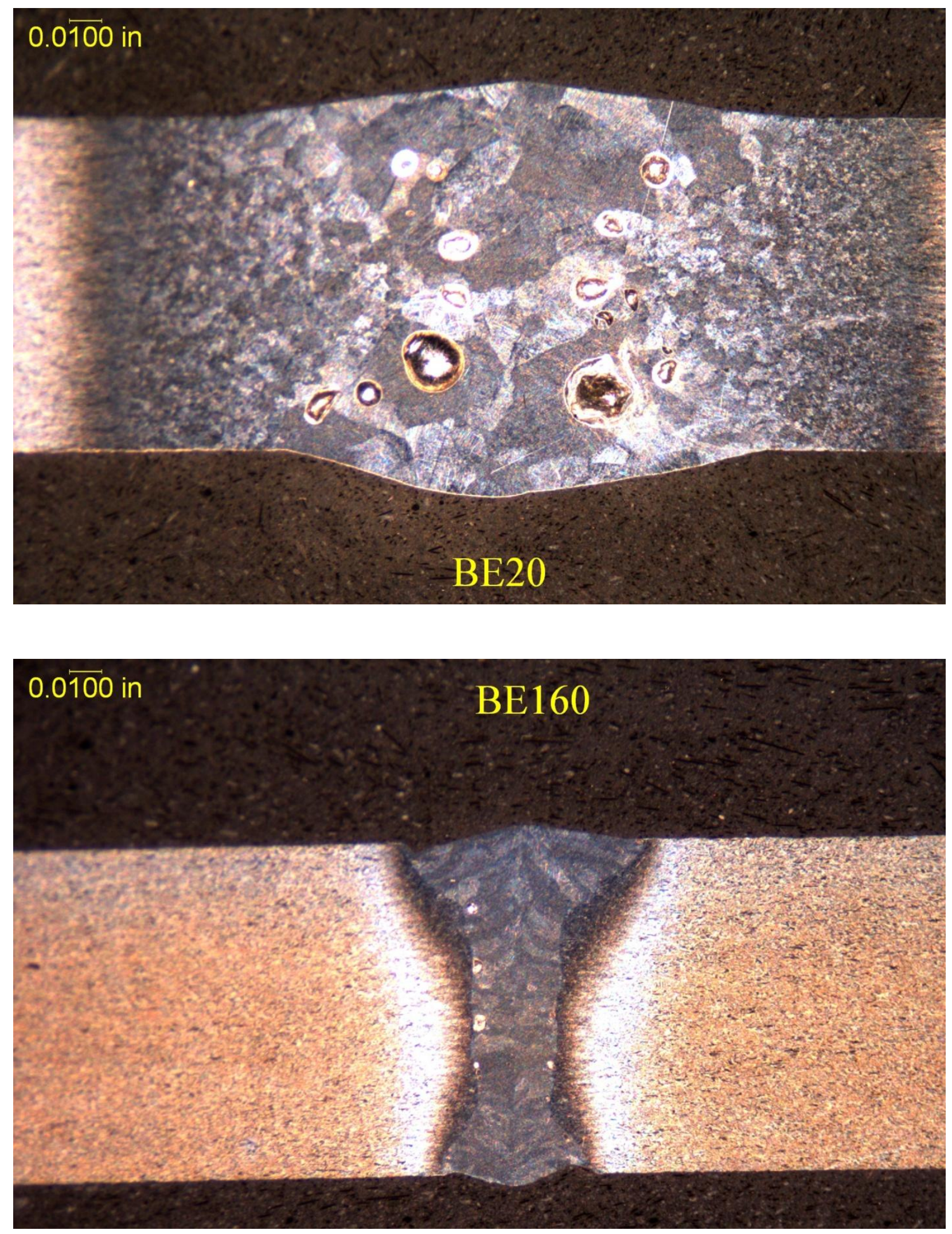

Figure 25. Effect of welding speed on weld zone characteristics in BE Ti-6Al-4V plate. 

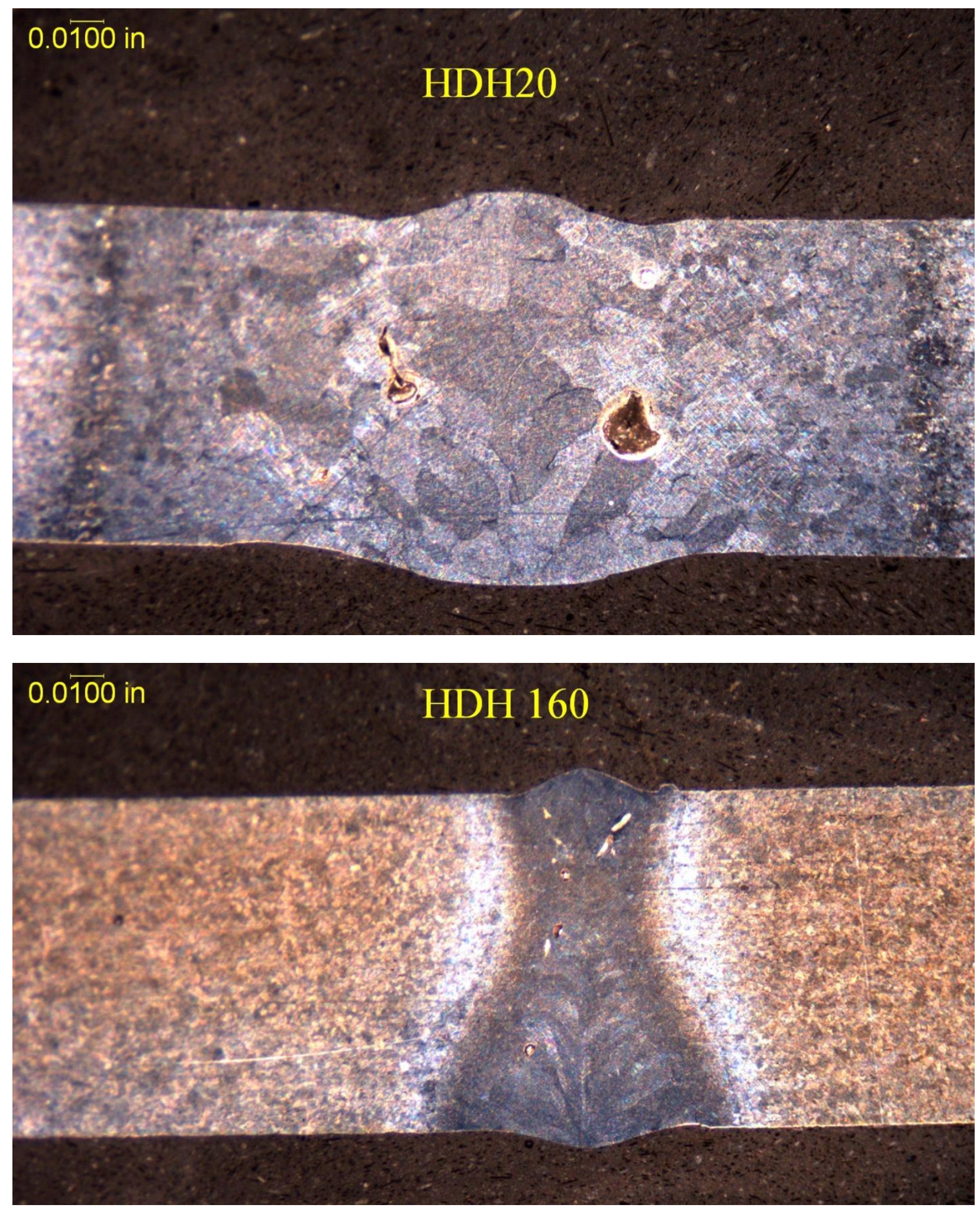

Figure 26. Effect of welding speed on weld zone characteristics in HDH Ti-6Al-4V material. 


\section{Gas Tungsten Arc (GTA) Welding}

Gas tungsten arc (GTA) welding studies of titanium PM materials were performed at ORNL. A series of bead-on-plate welds were produced using different power levels and speeds, as illustrated in Figure 27.
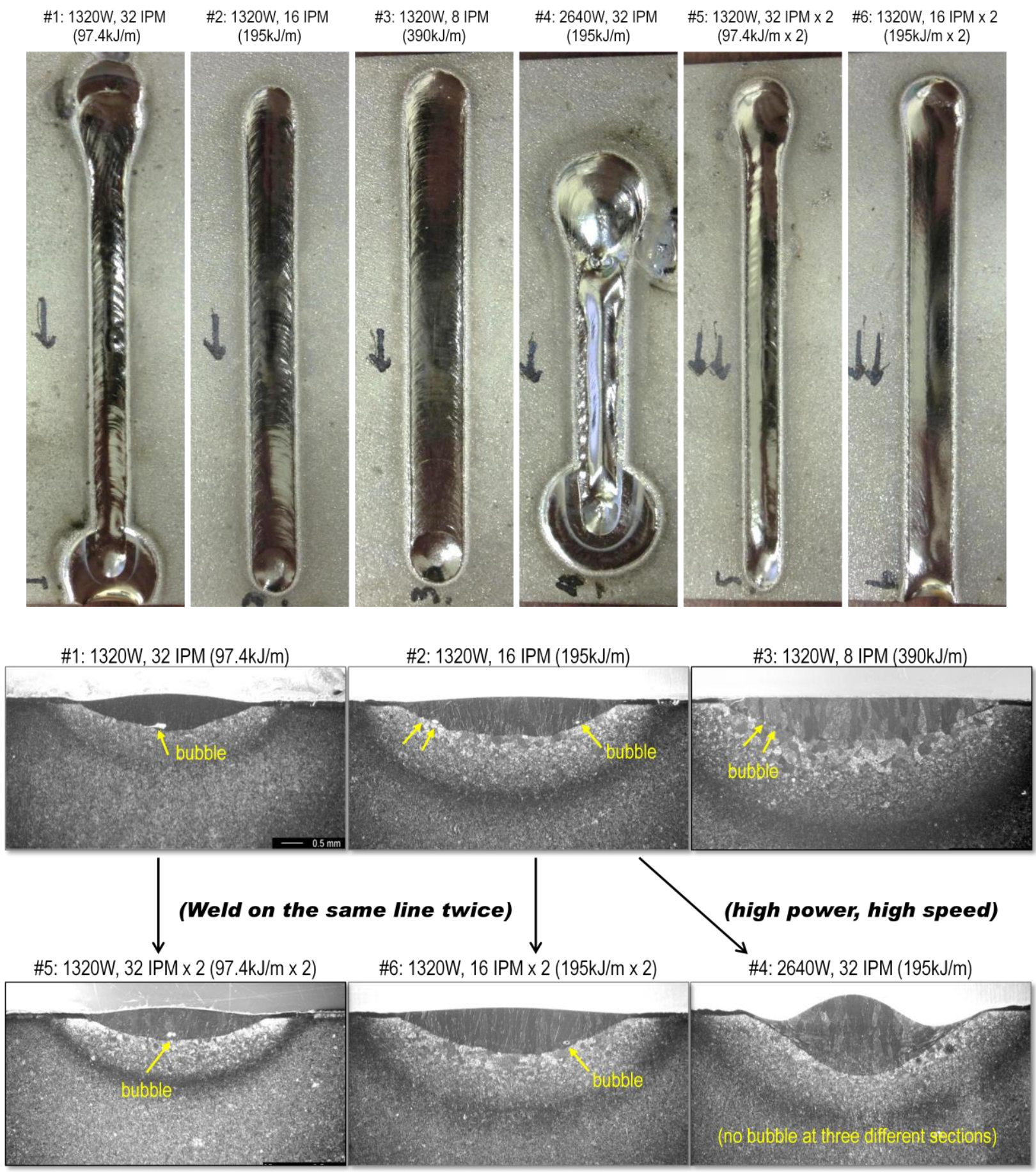

Figure 27. GTA welds and cross sectional views of PM HDH Ti-6Al-4V plate. 
Porosity is observed similar to that found in the laser welded materials. Also, the pores are again concentrated along the melt zone - base metal interface, rather than the weld centerline. Slowing the linear speed to allow more time for outgassing of molten metal did not affect the porosity. Also, remelting the weld bead with a second weld pass showed no significant change in outcome, as evidenced by comparing weld samples \#1 and \#5 and \#2 and \#6 in Figure 27. The power was increased in sample \#4 substantially to induce stirring of the weld pool and attempt to promote outgassing, and no pores were observed in this sample.

A small amount of available Ti-6Al-4V Armstrong powder, produced in ITP's pilot plant facility in Lockport, IL, was used to prepare a small plate by vacuum hot pressing at ORNL. GTA welding was performed on this plate as shown in Figure 28, welded at a speed of $32 \mathrm{in} / \mathrm{min}$ with $11 \mathrm{~V}$ and $120 \mathrm{~A}(97 \mathrm{~kJ} / \mathrm{m})$ with argon gas shielding. The weld specimen was cross-sectioned and examined by optical metallography. The optical micrograph in Figure 29 again shows porosity along the edge of the weld fusion zone. There does not appear to be any difference in behavior between HDH Ti-6Al-4V plate and Armstrong Ti-6Al-4V plate.

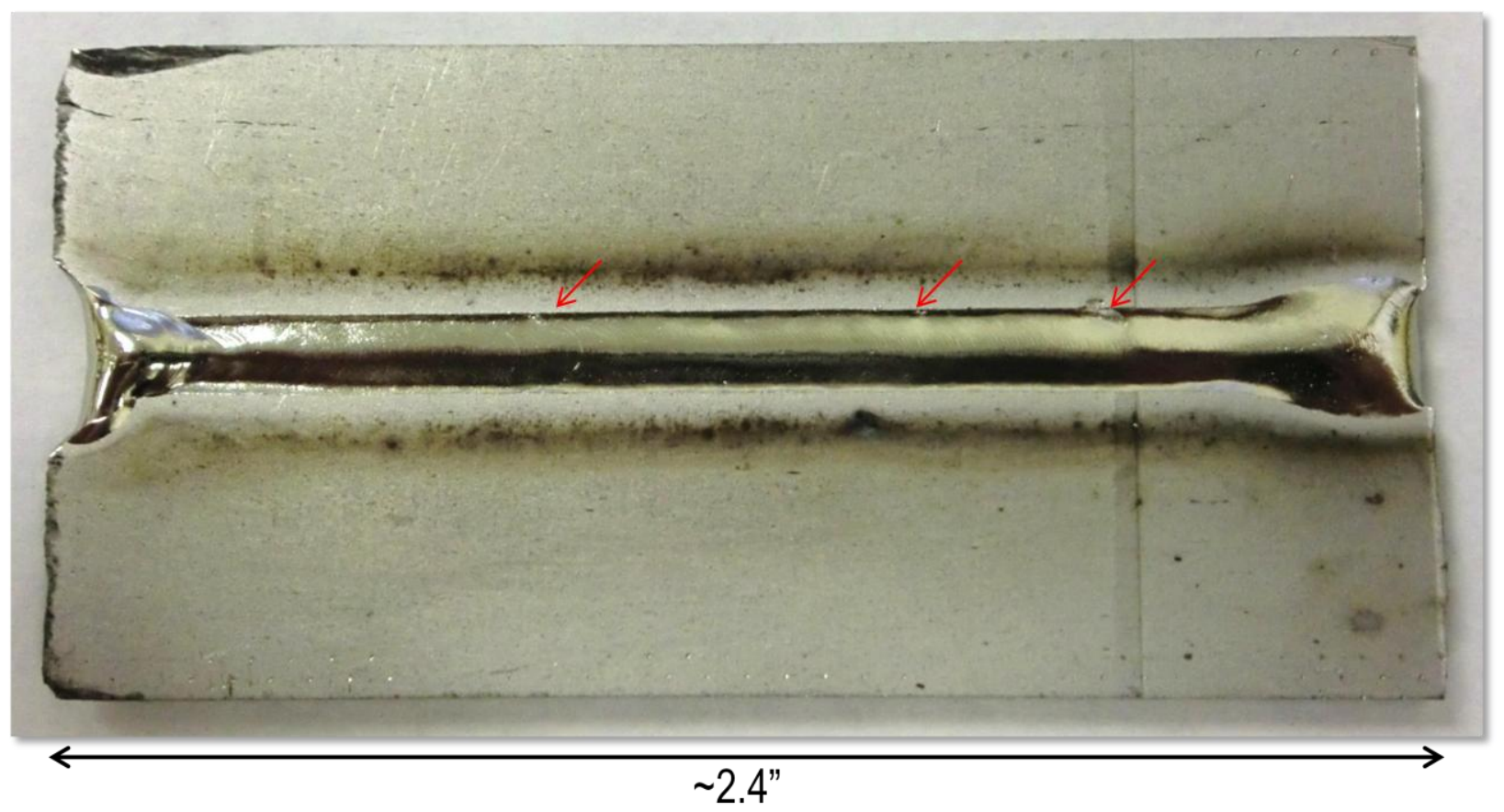

Figure 28. GTA weld on experimental Armstrong Ti-6Al-4V PM Plate 


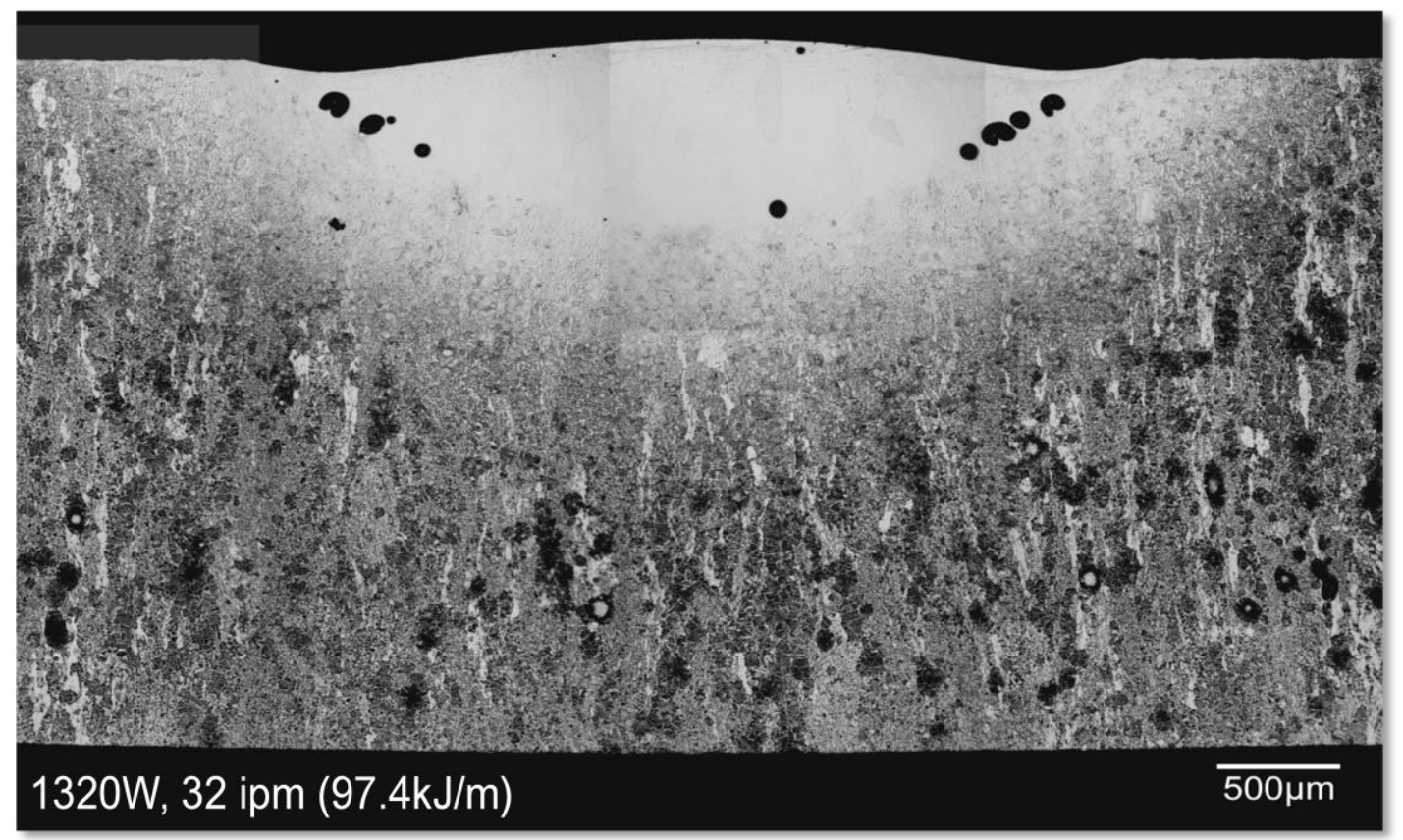

Figure 29. Cross section of GTA welded Armstrong Ti-6Al-4V Plate

Electron beam (EB) welding studies were also performed at ORNL on both PM and conventional titanium materials. EB welds were produced on commercial Ti-6Al-4V plate, HDH Ti-6Al-4V PM plate, and a small experimental Armstrong Ti-6Al-4V plate fabricated at ORNL. The two bead-on-plate welds shown in Figure 30 were produced in vacuum at $125 \mathrm{kV}, 7.5 \mathrm{~mA}$, and 25 in $/ \mathrm{min}(88.6 \mathrm{~kJ} / \mathrm{m})$ for weld $\# 1$ and $125 \mathrm{kV}, 19 \mathrm{~mA}$, and $65 \mathrm{in} / \mathrm{min}(86.3 \mathrm{~kJ} / \mathrm{m})$ for weld \#2. Weld \#2 showed large pores on the surface along the weld bead - base metal interface. Welds were sectioned and the cross section was observed by optical metallography. Weld cross sections in Figure 31 show the extensive porosity present in both EB welds.

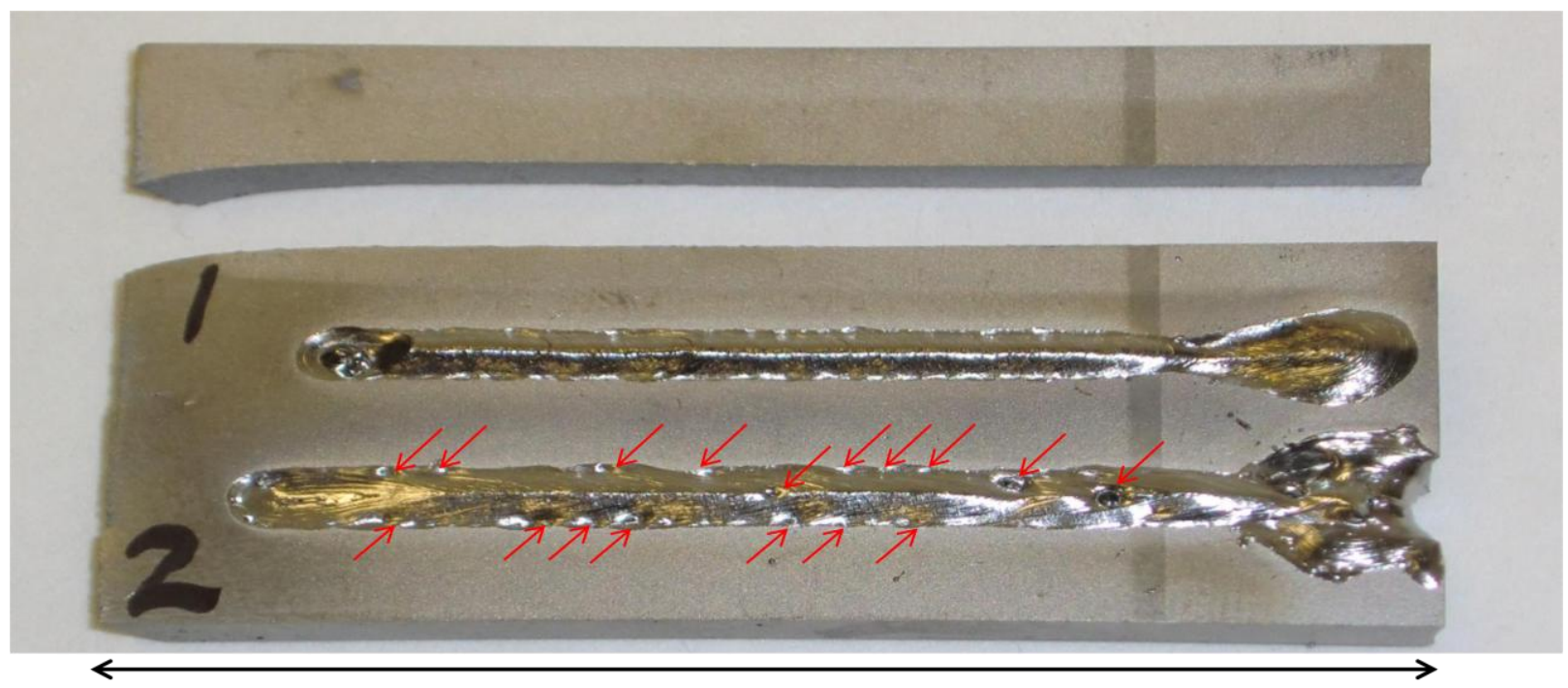

Figure 30. Electron beam welded Armstrong Ti-6Al-4V plate. 


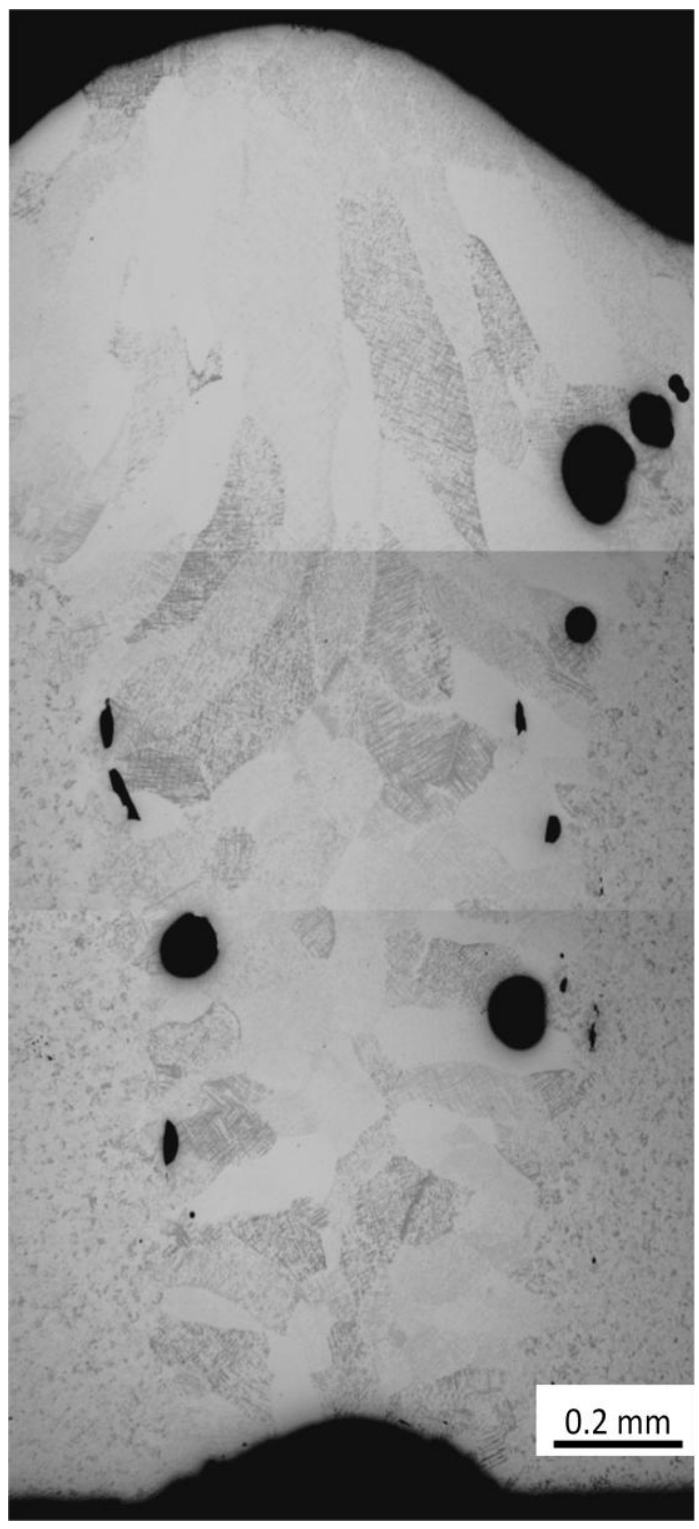

938W, $25 \mathrm{ipm}(88.6 \mathrm{~kJ} / \mathrm{m})$

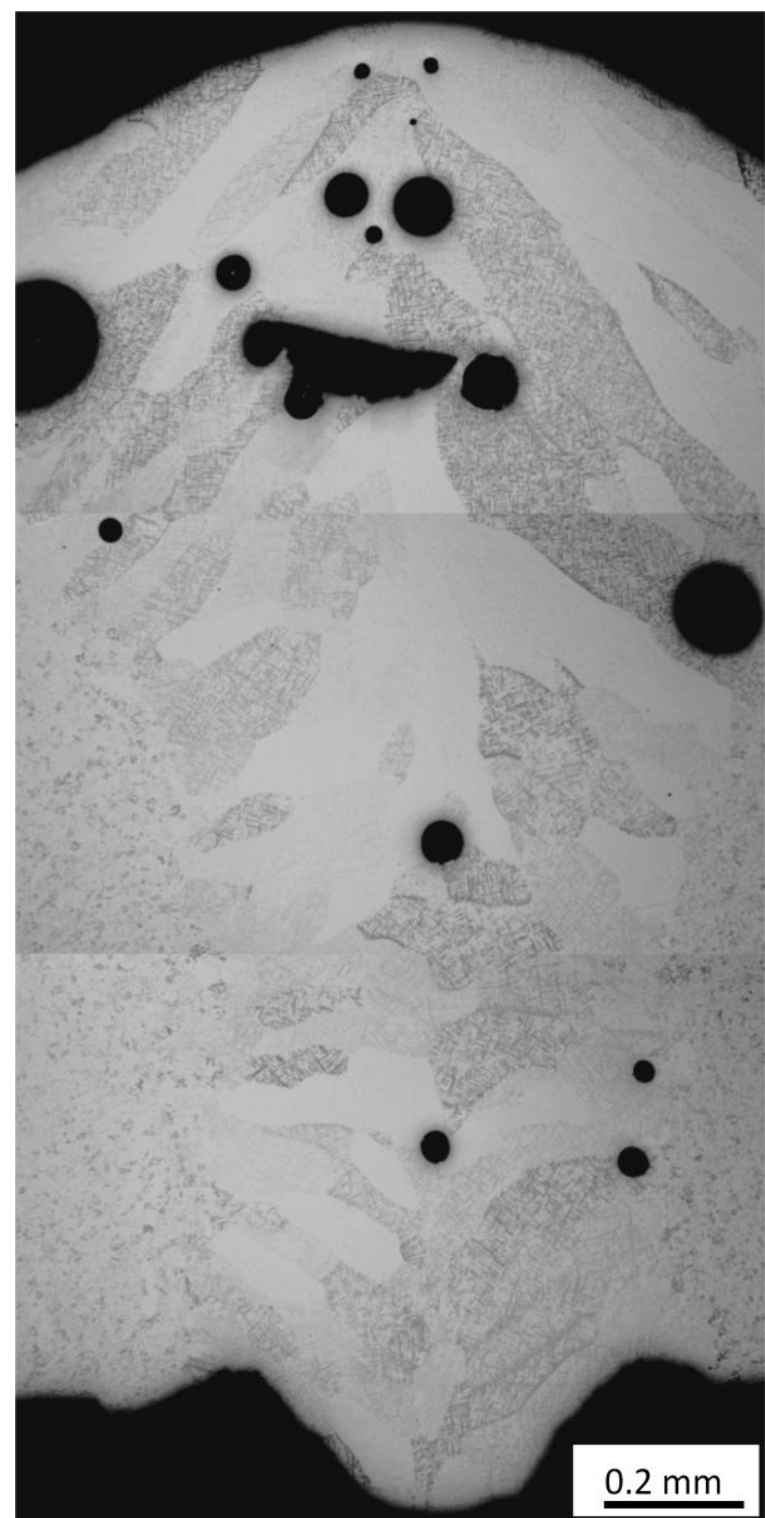

$2375 \mathrm{~W}, 65 \mathrm{ipm}(86.3 \mathrm{~kJ} / \mathrm{m})$

Figure 31. Optical micrographs of EB welds in Armstrong Ti-6Al-4V plate.

To determine if a second weld pass would alleviate the porosity, a series of five materials were welded as shown in Figures 32-36: commercial ingot metallurgy $\mathrm{CP}$ Ti and Ti-6Al-4V plate, and experimental powder metallurgy Armstrong $\mathrm{CP}$ Ti and Ti-6Al-4V and HDH Ti-6Al-4V plates. For each of these materials, welds were examined after a single weld pass and then after a second pass to determine if an additional melt cycle could eliminate the contaminant causing the porosity issue. This approach was taken, since melting is a very effective approach to eliminating common contaminants and producing clean metal chemistries. The weld parameters used for each specimen are indicated in the figures. 


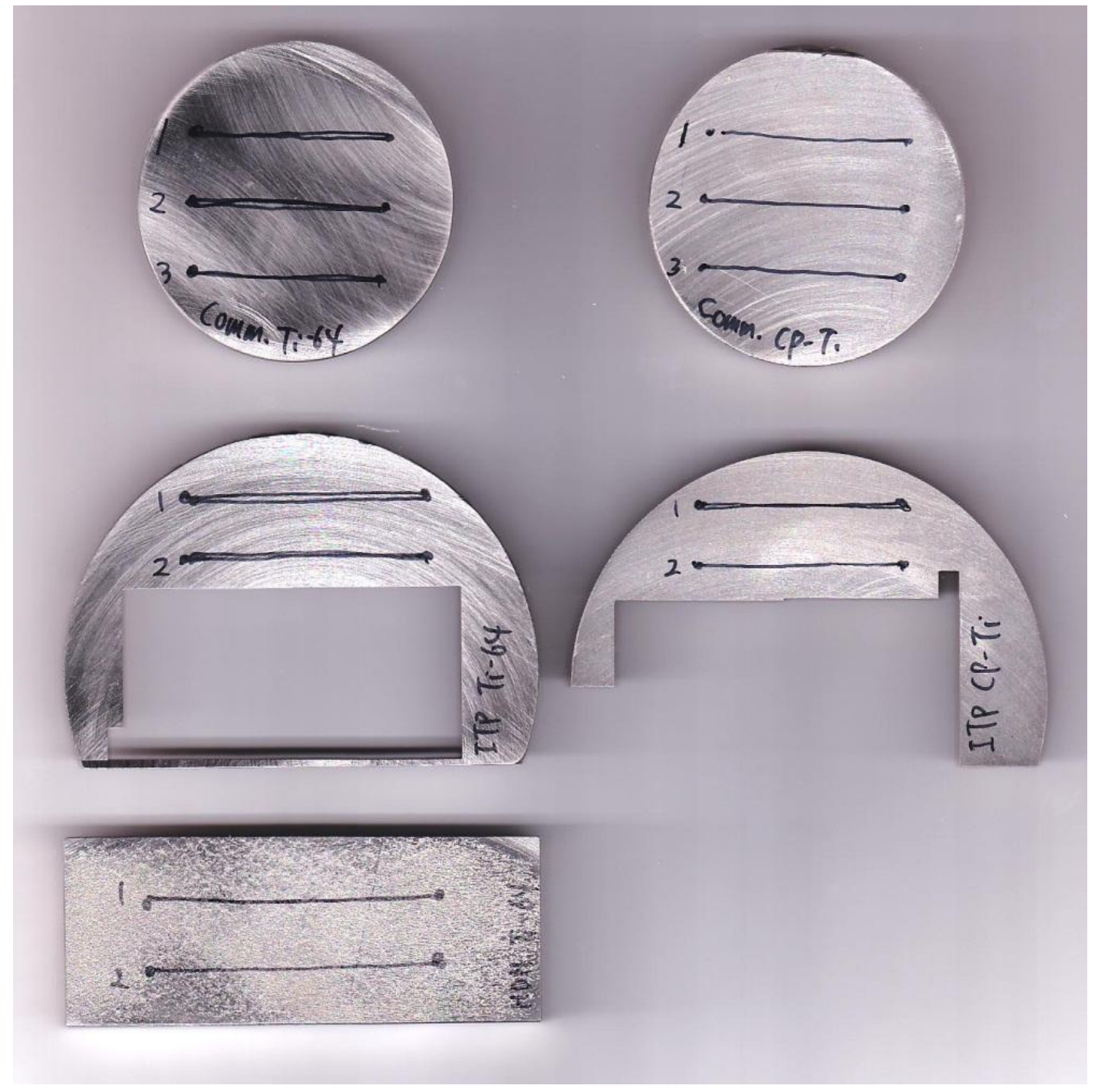

Figure 32. Electron Beam (EB) Weld Titanium Test Specimens 


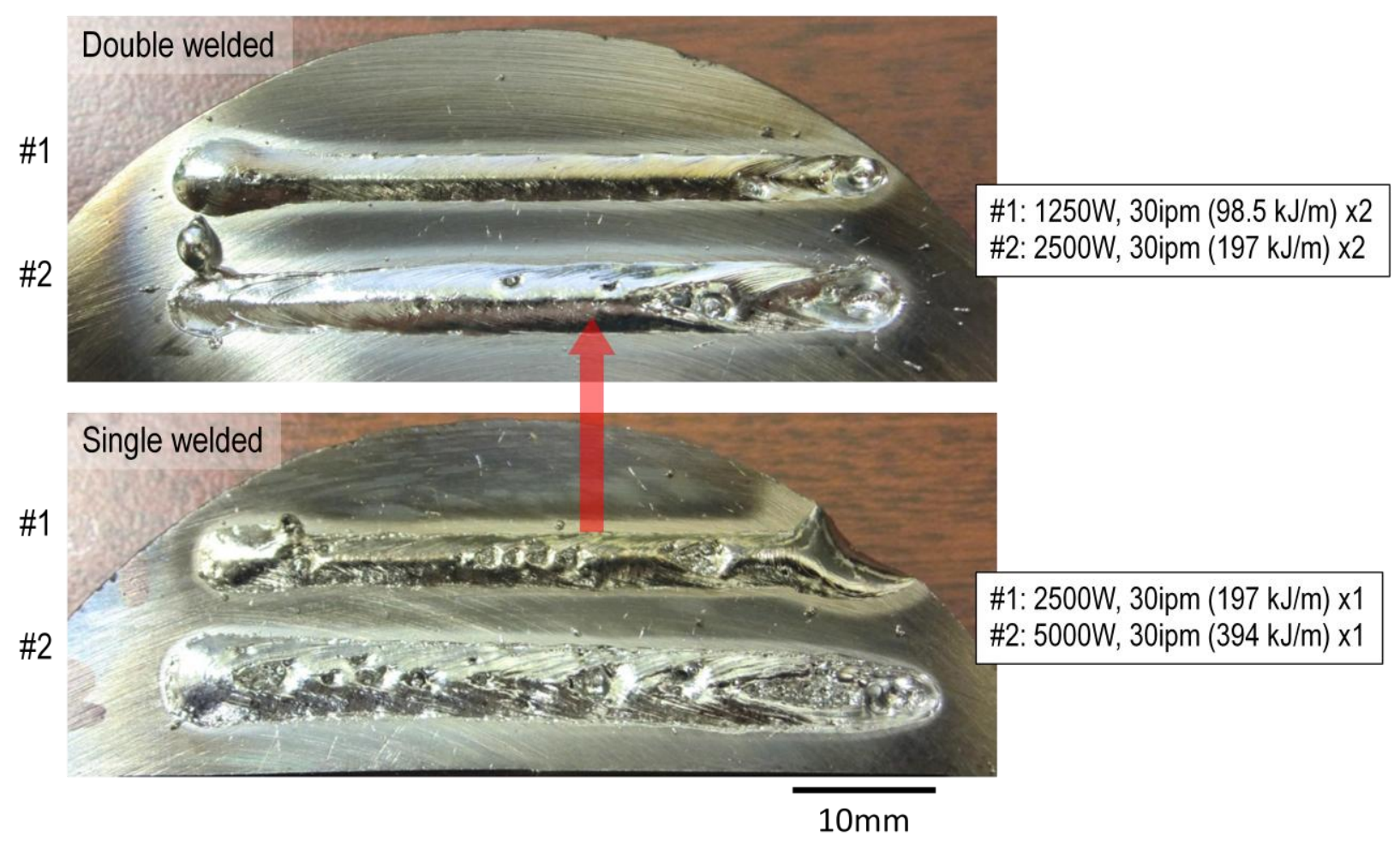

Figure 33. Electron beam welded Armstrong CP Ti plate.

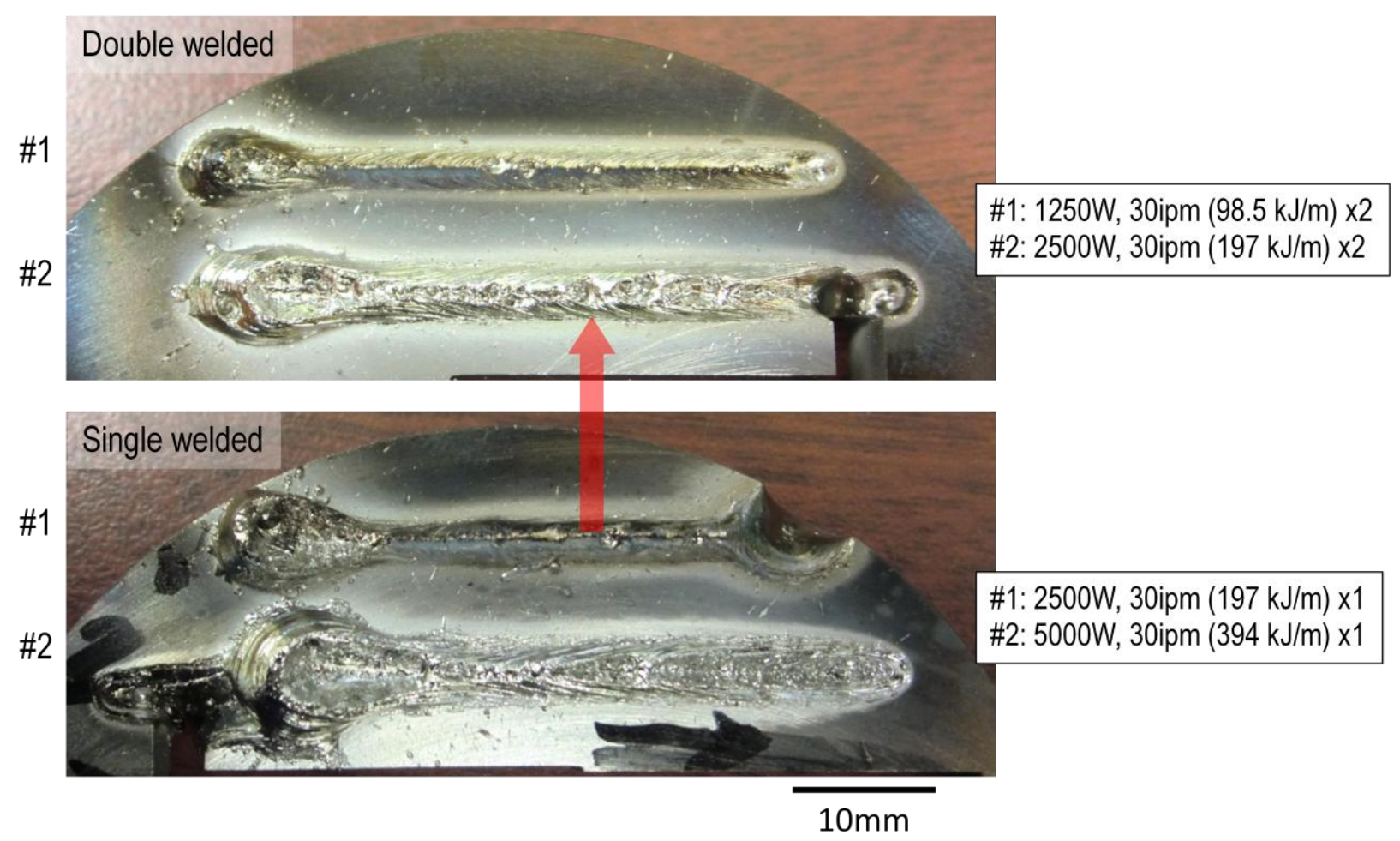

Figure 34. Electron beam welded Armstrong Ti-6Al-4V PM plate. 


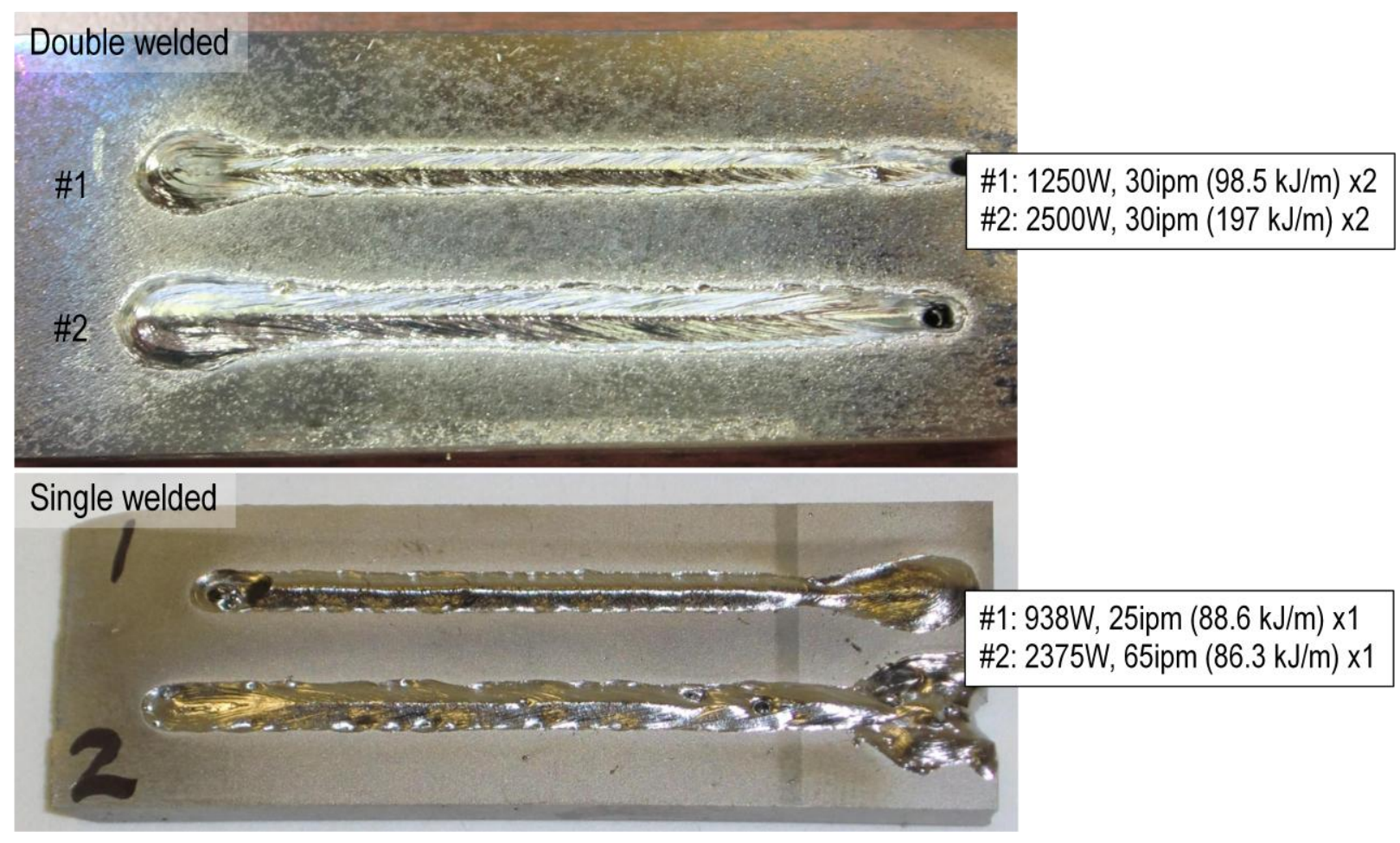

Figure 35. EB welded HDH Ti-6Al-4V PM plates.

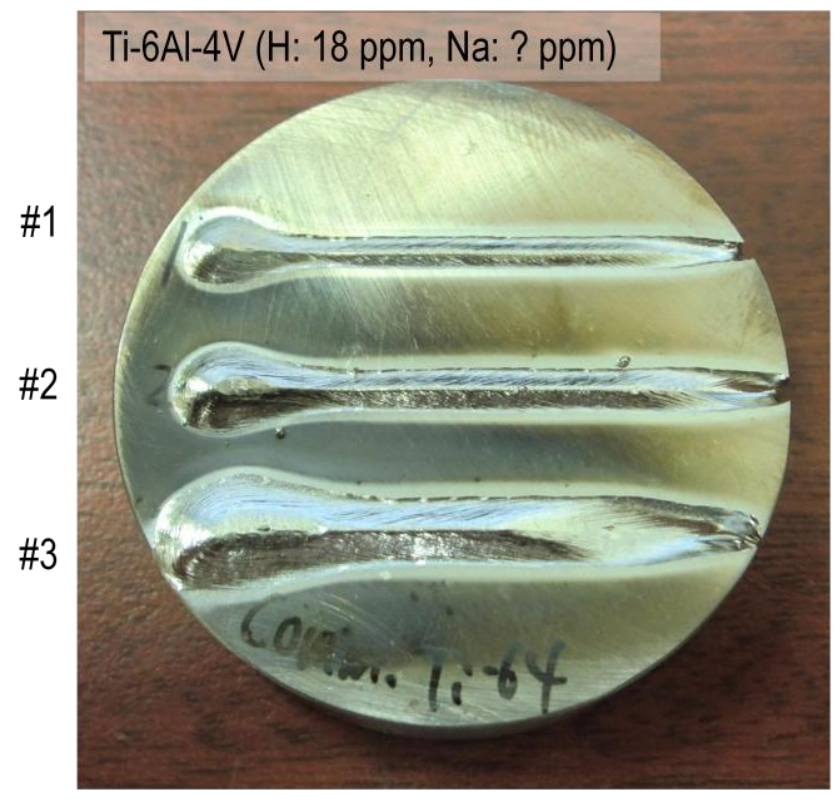

- No bubbling can be observed at any weld conditions studied.

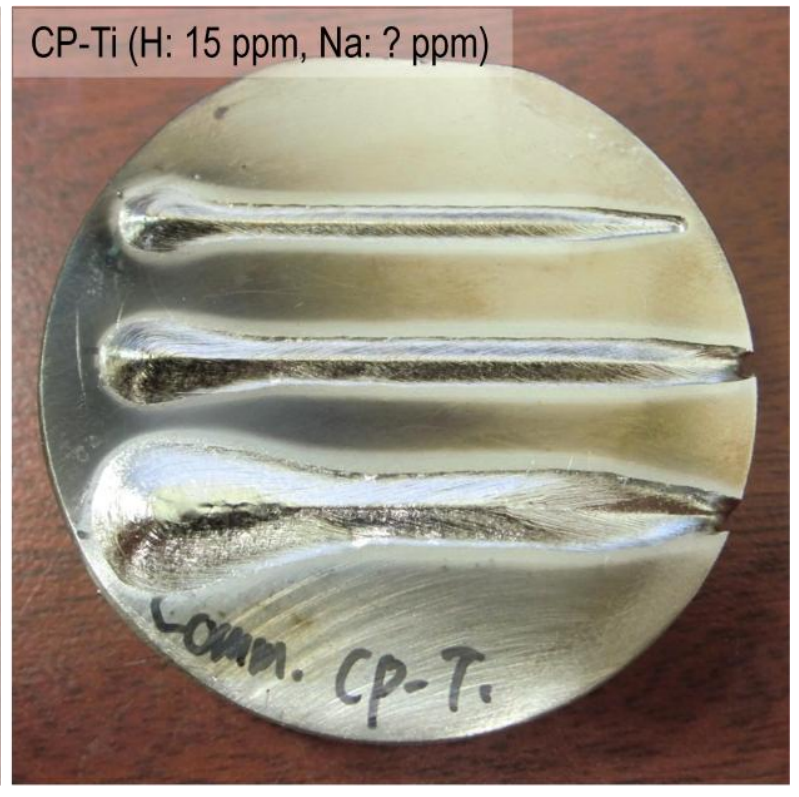

1. $125 \mathrm{kV} \times 10 \mathrm{~mA}(1250 \mathrm{~W}), 30 \mathrm{ipm}=98.5 \mathrm{~kJ} / \mathrm{m}$

2. $125 \mathrm{kV} \times 20 \mathrm{~mA}(2500 \mathrm{~W}), 30 \mathrm{ipm}=197 \mathrm{~kJ} / \mathrm{m}$

3. $125 \mathrm{kV} \times 40 \mathrm{~mA}(5000 \mathrm{~W}), 30 \mathrm{ipm}=394 \mathrm{~kJ} / \mathrm{m}$

Figure 36. EB welded commercial CP Ti and Ti-6Al-4V plates. 
Similar results were obtained for laser welds in pre-alloyed HDH material, as shown in Figures 35 and 36. These results are very similar to those obtained for the blended elemental (BE) plate. For each of the powder metallurgy materials, porosity was observed after the first weld pass, evidenced by small bubbles along the surface of the weld bead. A second pass over the same material did not appear to reduce the incident of bubbling. However, for the ingot metallurgy materials, no porosity was observed after either one or two weld passes. These results indicate that fusion welding of powder metallurgy materials is problematic, due to some type of contamination. It is not clear what the contaminant is for a given powder source, or if there is a chemical issue common to PM materials. Solid state joining methods, such as linear friction welding and friction stir welding, may be required to fabricate machining performs using these powder metallurgy mill products. And, in fact, these joining methods may be enabling technologies for fabrication of welded structures and performs using PM materials.

In an attempt to identify the chemical issues related to porosity, a series of melting studies were performed at ORNL. A sample of Armstrong CP Ti powder was melted and a temperatureprogrammed desorption mass spectrometer (TPD-MS) was used to analyze any gases given off during melting. Powder was vibratory milled in deionized water for 10 minutes and dried in an air oven at $50^{\circ} \mathrm{C}$ for 12 hours. After drying, the oxygen content of the powder was determined to be $0.24 \mathrm{wt} \%$, and the nitrogen content was $0.02 \mathrm{wt} \%$. The analysis was performed after flushing at $25^{\circ} \mathrm{C}$ for 2 hours with $\mathrm{He}$ gas followed by continuous heating at $10^{\circ} \mathrm{C} / \mathrm{min}$ to a peak temperature of $950^{\circ} \mathrm{C}$. A second analysis was performed with step heating at $10^{\circ} \mathrm{C} / \mathrm{min}$ to $300^{\circ} \mathrm{C}$ and holding for 2 hours, followed by heating at $10^{\circ} \mathrm{C} / \mathrm{min}$ to $950^{\circ} \mathrm{C}$. Results of these experiments are presented in Figures 37 through 40. 


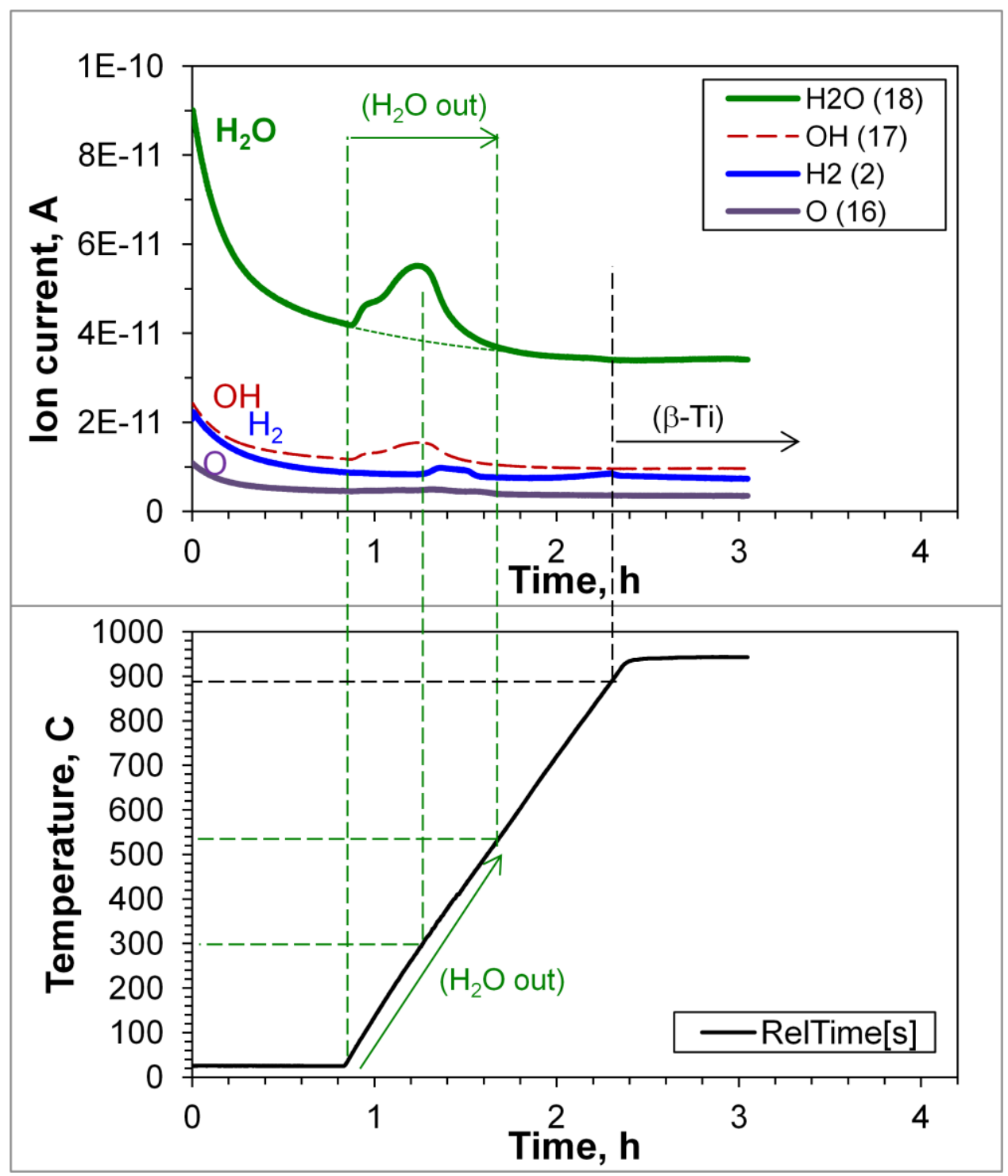

Figure 37. Results of temperature-programmed mass spectrometry (TPD-MS) of Armstrong CP Ti powder showing gases driven off during continuous heating. 


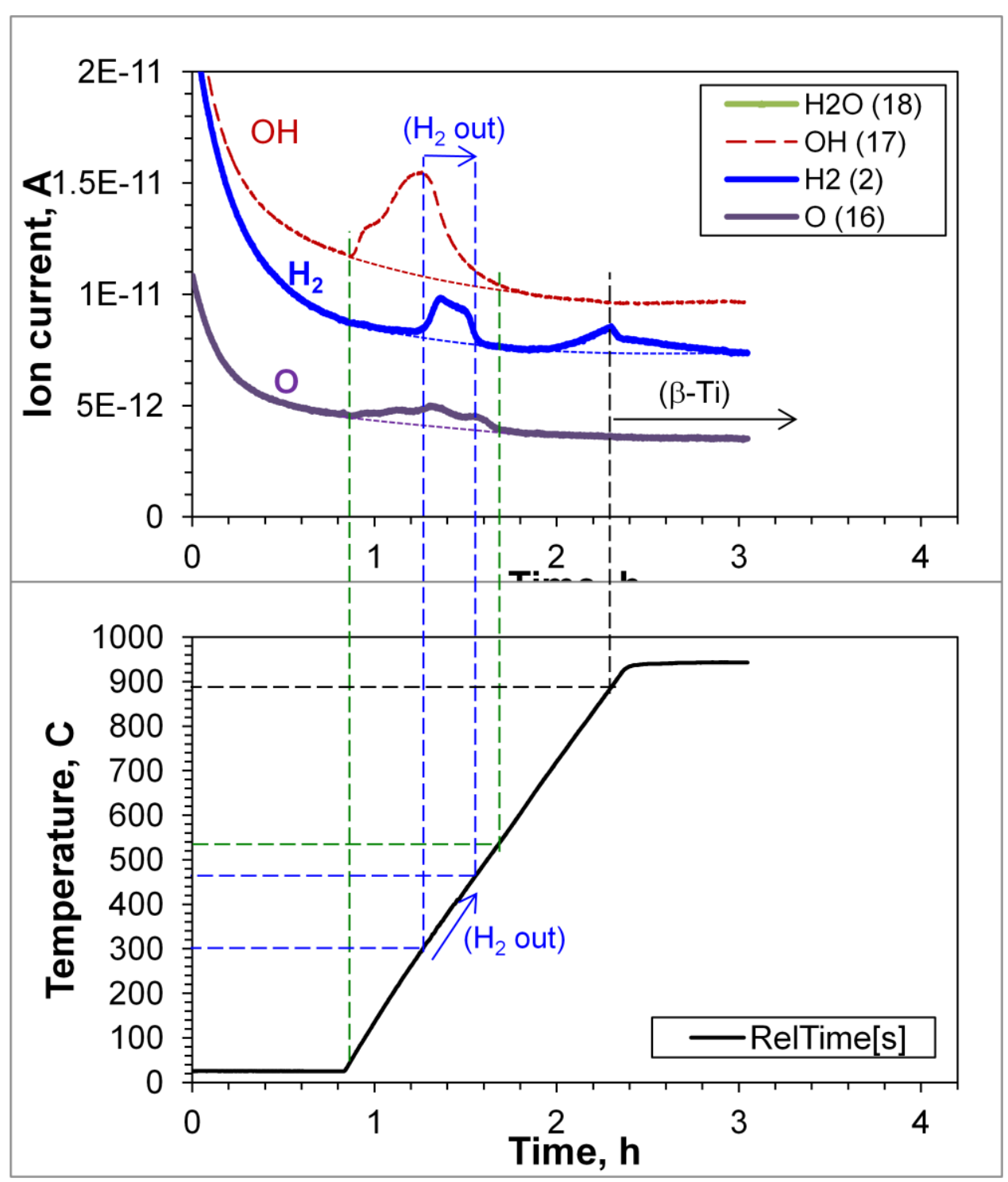

Figure 38. Results of temperature-programmed mass spectrometry (TPD-MS) of Armstrong CP Ti powder showing gases driven off during continuous heating (expanded scale to show details). 


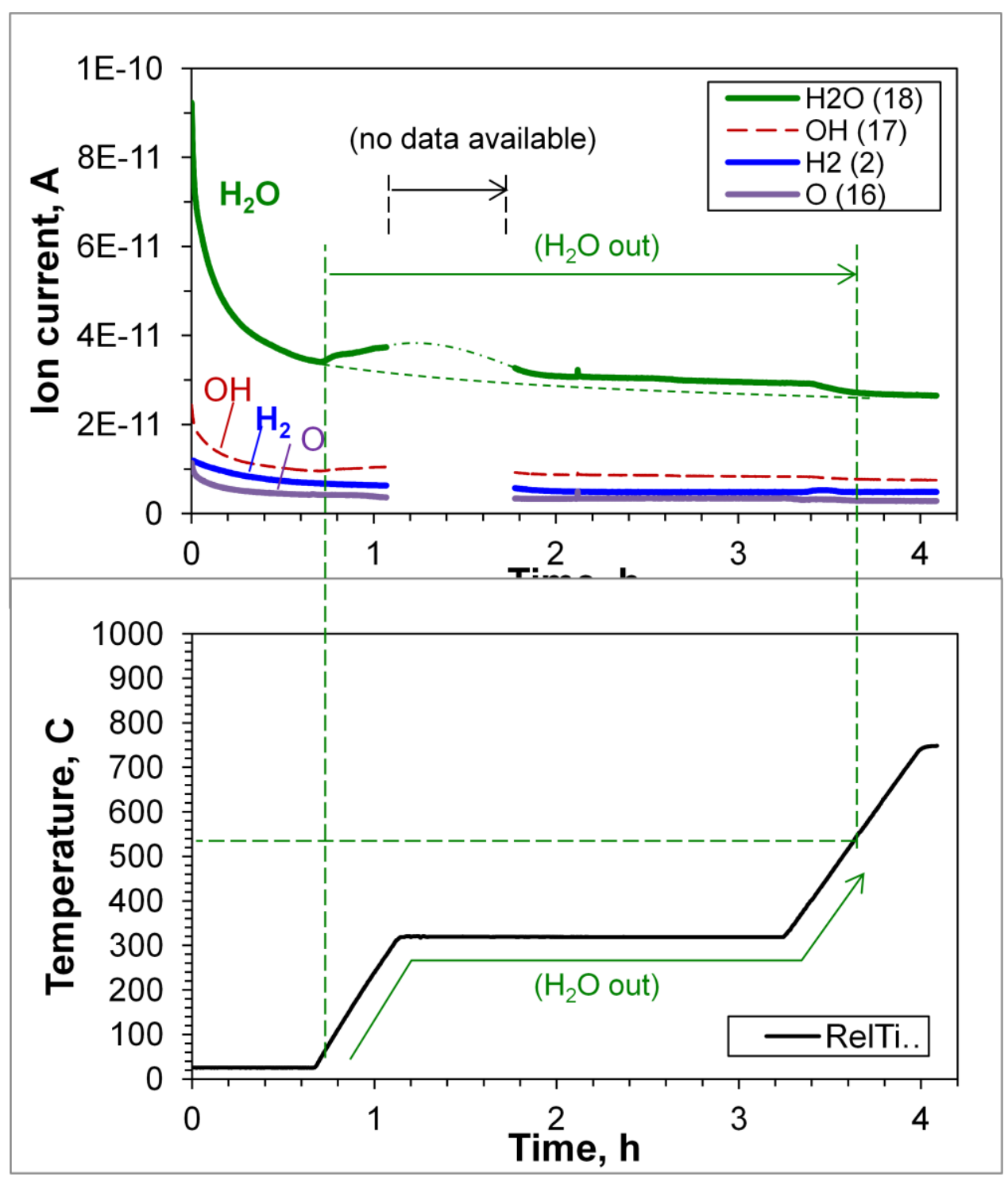

Figure 39. Results of temperature-programmed mass spectrometry (TPD-MS) of Armstrong CP Ti powder showing gases driven off during step heating. 


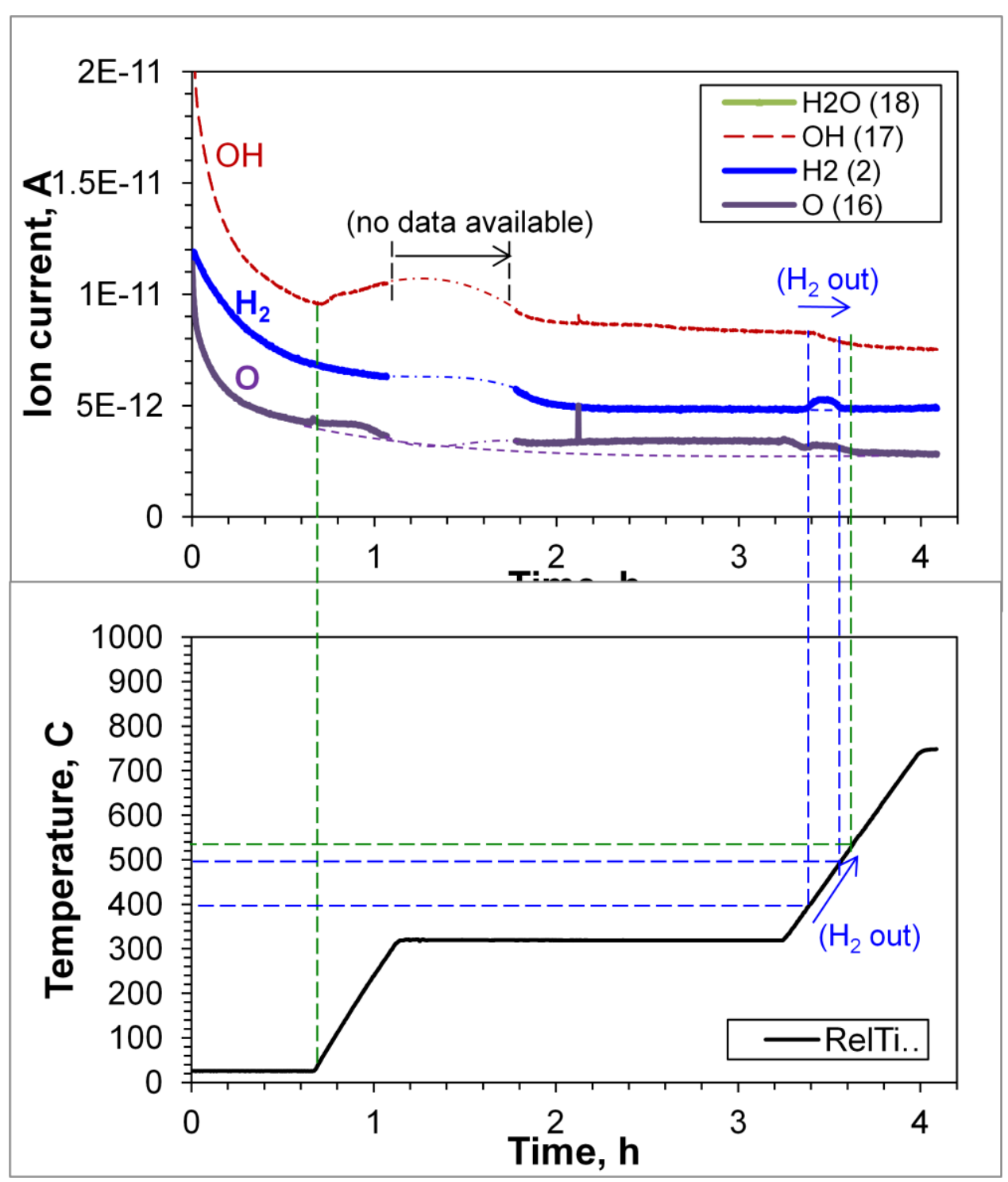

Figure 40. Results of temperature-programmed mass spectrometry (TPD-MS) of Armstrong CP Ti powder showing gases driven off during step heating (expanded scale to show details). 
Analysis of the TPD-MS results shows that $\mathrm{H}_{2} \mathrm{O}$ water vapor was driven off from the powder from room temperature up to about $520^{\circ} \mathrm{C}$, with peak expulsion at around $300^{\circ} \mathrm{C}$. Hydrogen gas $\mathrm{H}_{2}$ was driven off from $300^{\circ} \mathrm{C}$ to approximately $460^{\circ} \mathrm{C}$, indicating decomposition of $\mathrm{H}_{2} \mathrm{O}$ into $\mathrm{H}$ and $\mathrm{O}$. For step heating, $\mathrm{H}_{2} \mathrm{O}$ degassed continuously during baking at $300^{\circ} \mathrm{C}$, and $\mathrm{H}_{2}$ degassed from about $400^{\circ} \mathrm{C}$ after baking, with much less $\mathrm{H}_{2}$ gas observed than for continuous heating. It is possible that titanium is cracking the $\mathrm{H}_{2} \mathrm{O}$, forming $\mathrm{H}_{2}$ gas and elemental oxygen which is absorbed by the titanium into solid solution.

Additional arac melting trials were performed on various powder metallurgy materials to provide additional insight into why PM materials are difficult to fusion weld. Before and after melting chemical analysis was performed to see if either or both $\mathrm{H}$ or $\mathrm{Na}$ were gas-generating species and to determine if $\mathrm{Na}$ contamination was present in Na-reduced Armstrong powders as $\mathrm{NaCl}, \mathrm{Na}_{2} \mathrm{O}$, $\mathrm{Na}$ or $\mathrm{NaOH}$ (Figure 41).

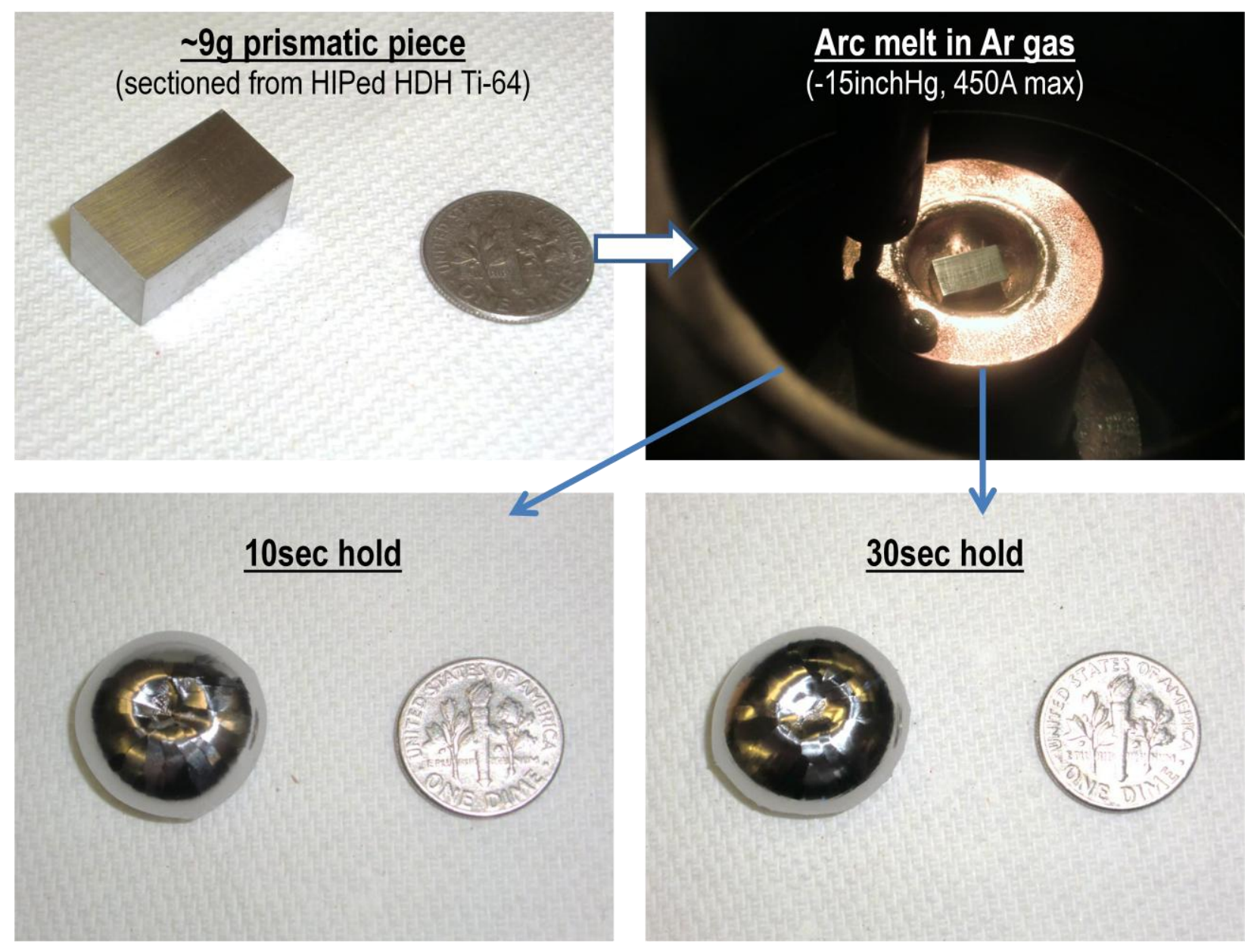

Figure 41. Arc melting experiments of powder metallurgy titanium samples.

Based on the results of chemical analysis, summarized in Tables 17 and 18, the amount of hydrogen and $\mathrm{Mg} / \mathrm{Na}$ in the powder materials decreased significantly after melting. The Armstrong powder sample showed high weight loss due to aggressive bubbling at the beginning of arc melting. 


\begin{tabular}{|c|c|c|c|c|c|c|c|c|c|}
\hline ID & $\mathrm{C} 1-1$ & $\mathrm{C} 1-2$ & $\mathrm{C} 2-1$ & $\mathrm{C} 2-2$ & $\mathrm{C} 2-3$ & C3-1 & $\mathrm{C} 3-2$ & D1-1 & D1-2 \\
\hline Sample & \multicolumn{2}{|c|}{ I/M Ti-6Al-4V } & \multicolumn{3}{|c|}{ PM HDH Ti-6Al-4V } & \multicolumn{2}{|c|}{ PM BE Ti-6Al-4V } & \multicolumn{2}{|c|}{ PM Armstrong Ti-6Al-4V } \\
\hline status & no melt & melt 30sec & no melt & melt $10 \mathrm{sec}$ & melt 30sec & no melt & melt 30sec & no melt & melt 30sec \\
\hline Hydrogen & $18 \mathrm{ppm}$ & 16 ppm & $150 \mathrm{ppm}$ & $59 \mathrm{ppm}$ & $51 \mathrm{ppm}$ & $26 \mathrm{ppm}$ & $15 \mathrm{ppm}$ & $14 \mathrm{ppm}$ & $10 \mathrm{ppm}$ \\
\hline Oxygen & 0.159 & 0.178 & 0.139 & 0.147 & 0.143 & 0.197 & $0.205 / 0.208$ & $0.423 / 0.424$ & $0.395 / 0.393$ \\
\hline Nitrogen & 0.009 & 0.010 & 0.025 & 0.027 & 0.026 & 0.024 & 0.024 & 0.031 & 0.034 \\
\hline Aluminum & 6.26 & 6.32 & 6.28 & 6.23 & 6.35 & 6.18 & 6.06 & 6.68 & 7.12 \\
\hline Magnesium & $<5 \mathrm{ppm}$ & $<5 \mathrm{ppm}$ & $<5 \mathrm{ppm}$ & $<5 \mathrm{ppm}$ & $<5 \mathrm{ppm}$ & $22 \mathrm{ppm}$ & $<5 \mathrm{ppm}$ & - & - \\
\hline Sodium & - & - & - & - & - & - & - & $<5 \mathrm{ppm}$ & $<5 \mathrm{ppm}$ \\
\hline Chloride & $<10 \mathrm{ppm}$ & $<10 \mathrm{ppm}$ & $<10 \mathrm{ppm}$ & $<10 \mathrm{ppm}$ & $<5 \mathrm{ppm}$ & $<5 \mathrm{ppm}$ & $<5 \mathrm{ppm}$ & $<10 \mathrm{ppm}$ & $<10 \mathrm{ppm}$ \\
\hline $\begin{array}{c}\text { Weight } \\
\text { loss } \\
\text { after } \\
\text { melting, \% }\end{array}$ & - & 0.01 & - & 0.06 & 0.04 & - & 0.04 & - & 1.23 \\
\hline
\end{tabular}

Table 17. Chemistry of conventional wrought and powder metallurgy Ti-6Al-4V specimens before and after melting. 


\begin{tabular}{|c|c|c|c|c|c|c|c|}
\hline \multirow{2}{*}{$\begin{array}{l}\text { ID } \\
\text { sample }\end{array}$} & A11 & A $1-2$ & A2-1 & A2-2 & B1-1 & B $1-2$ & \\
\hline & \multicolumn{2}{|c|}{ I/M Ti-6Al-4V } & \multicolumn{2}{|c|}{ PM HDH Ti-6Al-4V } & \multicolumn{2}{|c|}{ PM Armstrong Ti-6Al-4V } & \\
\hline status & no melt & melt 30sec & no melt & melt 30sec & no melt & melt $30 \mathrm{sec}$ & \\
\hline Hydrogen & $15 \mathrm{ppm}$ & $18 \mathrm{ppm}$ & $120 \mathrm{ppm}$ & $54 \mathrm{ppm}$ & $44 \mathrm{ppm}$ & $19 \mathrm{ppm}$ & $\mathrm{H}$ \\
\hline Oxygen & 0.144 & 0.134 & $0.231 / 0.225$ & $0.236 / 0.233$ & $0.311 / 0.316$ & $0.312 / 0.299$ & $\mathrm{O}$ \\
\hline Nitrogen & 0.012 & 0.012 & 0.008 & 0.009 & 0.029 & 0.031 & $\mathrm{~N}$ \\
\hline Magnesium & $<5 \mathrm{ppm}$ & $<5 \mathrm{ppm}$ & $92 \mathrm{ppm}$ & $<5 \mathrm{ppm}$ & - & - & $\mathrm{Mg}$ \\
\hline Sodium & - & - & - & - & $240 \mathrm{ppm}$ & $<5 \mathrm{ppm}$ & $\mathrm{Na}$ \\
\hline Chloride & $<10 \mathrm{ppm}$ & $<10 \mathrm{ppm}$ & $<10 \mathrm{ppm}$ & $<10 \mathrm{ppm}$ & $<10 \mathrm{ppm}$ & $<10 \mathrm{ppm}$ & $\mathrm{Cl}$ \\
\hline $\begin{array}{l}\text { Weight loss } \\
\text { after melting, \% }\end{array}$ & - & 0.01 & - & 0.41 & - & 5.03 & \\
\hline
\end{tabular}

Table 18. Chemistry of conventional wrought and powder metallurgy Ti-6Al-4V specimens before and after melting. 


\section{Linear Friction Welding}

For linear friction welding feasibility studies, we utilized HDH Ti-6Al-4V rectangular bar stock as a representative powder metallurgy material that was purchased by the program, machined to sample blocks measuring $3.5 \times 3 \times 2$ inches. APCI, Inc., South Bend, IN, produced a total of 12 joints using 6 variations of joining parameters, as illustrated in Figure 42. For LFW, one piece is held stationary while the other piece is pressed against it and vibrated at a high frequency to generate heat. Once the material at the interface becomes plastic, a forging force is applied that forces the two pieces together, with flash squeezing out of the joint as shown in the figure. Specimens were fabricated with the joint plane perpendicular to the longitudinal (L) and long transverse (LT) directions of the bar. LFW material was then heat treated to the mill annealed condition. Specimens were then machined for tensile testing Westmoreland Mechanical Testing \& Research Inc., Youngstown, PA. Tensile testing was performed per ASTM E8 standards for specimens oriented to the longitudinal (L) direction of the bar. Test results are presented in Table 19.

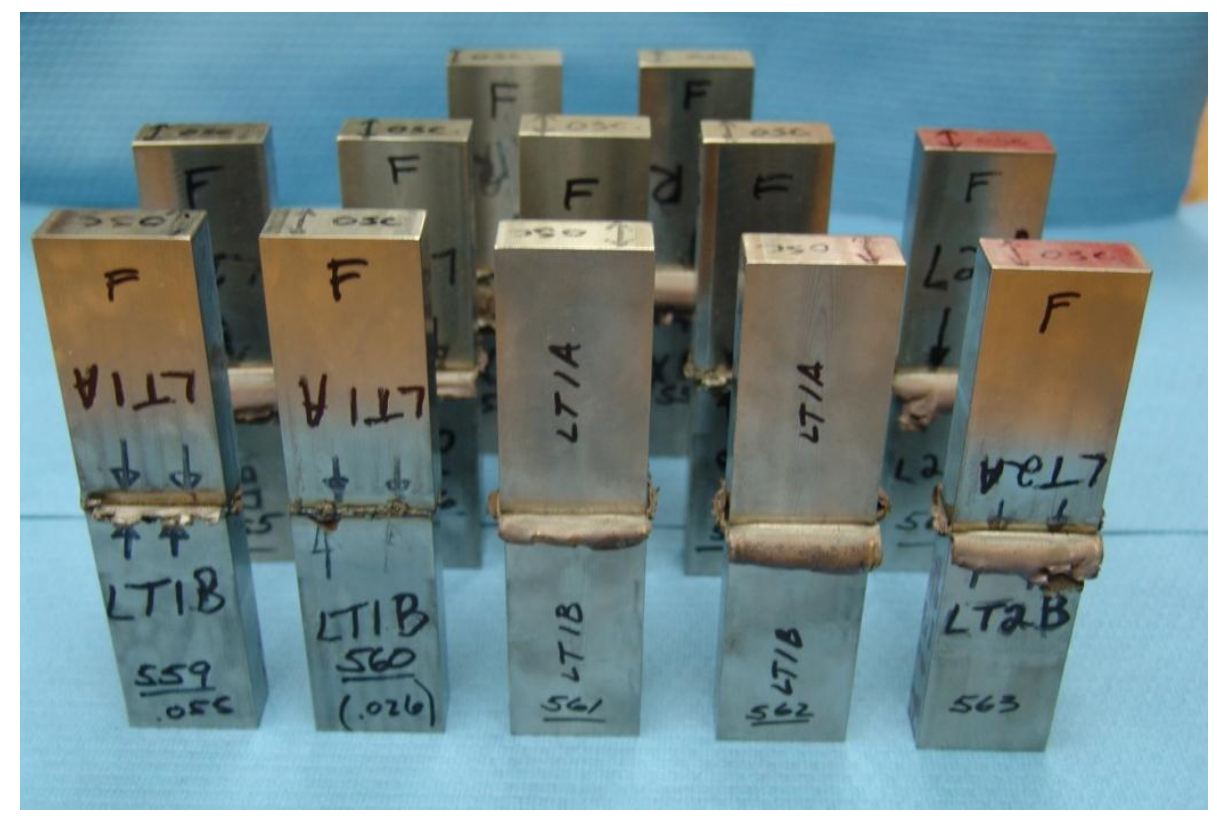

Figure 42. Linear Friction Welded (LFW) HDH Ti-6Al-4V specimens.

Tensile data illustrates that excellent strength and ductility can be achieved in NNS performs fabricated using linear friction welding. There are anomalies to the data, however, with a few very low strength and ductility values which require further investigation. However, a simple test program could be performed to refine the processing window for LFW and produce material that satisfied design property minimums with statistical confidence. 


\begin{tabular}{|c|c|c|c|c|}
\hline \multicolumn{5}{|c|}{ Tensile Properties of Linear Friction Welded HDH Ti-6Al-4V } \\
\hline $\begin{array}{l}\text { Specimen } \\
\text { No. }\end{array}$ & UTS, ksi & YS, ksi & Elong, \% & RA, \% \\
\hline 553-1 & 139.4 & 128.2 & 12 & 16 \\
\hline $553-2$ & 138.8 & 124.4 & 17 & 41 \\
\hline $553-3$ & 137.2 & 124.4 & 19 & 49 \\
\hline $554-1$ & 139.2 & 129.8 & 19 & 43 \\
\hline $554-2$ & 140.1 & 128.0 & 12 & 16 \\
\hline $554-3$ & 140.5 & 131.0 & 15 & 23 \\
\hline $555-1$ & 138.5 & 128.4 & 19 & 49 \\
\hline $555-2$ & 139.6 & 127.5 & 19 & 49 \\
\hline $555-3$ & 140.0 & 131.6 & 8 & 13 \\
\hline 556-1 & 139.2 & 127.7 & 20 & 52 \\
\hline $556-2$ & 138.9 & 125.3 & 15 & 39 \\
\hline $556-3$ & 139.7 & 128.5 & 18 & 47 \\
\hline $557-1$ & 52.2 & - & 0 & 3 \\
\hline $557-2$ & 117.4 & - & 5 & 4 \\
\hline $557-3$ & 138.0 & 125.2 & 18 & 40 \\
\hline $558-1$ & 108.7 & - & 0 & 3 \\
\hline $558-2$ & 140.5 & 129.3 & 16 & 42 \\
\hline $558-3$ & 140.2 & 131.4 & 18 & 46 \\
\hline $559-1$ & 142.8 & 133.4 & 16 & 40 \\
\hline $559-2$ & 142.2 & 131.7 & 16 & 34 \\
\hline 559-3 & 143.6 & 133.8 & 17 & 34 \\
\hline $560-1$ & 76.4 & - & 0 & 6 \\
\hline $560-2$ & 87.4 & - & 0 & 3 \\
\hline $560-3$ & 97.3 & - & 0 & 1 \\
\hline $561-1$ & 142.5 & 134.0 & 13 & 26 \\
\hline $561-2$ & 141.6 & 130.8 & 16 & 30 \\
\hline 561-3 & 142.3 & 133.2 & 8 & 10 \\
\hline $562-1$ & 142.4 & 133.6 & 17 & 38 \\
\hline $562-2$ & 141.2 & 129.7 & 16 & 36 \\
\hline $562-3$ & 141.7 & 133.5 & 6 & 6 \\
\hline 563-1 & 142.5 & 132.8 & 16 & 30 \\
\hline $563-2$ & 141.8 & 130.7 & 12 & 20 \\
\hline 563-3 & 143.3 & 134.6 & 13 & 34 \\
\hline $564-1$ & 140.0 & 130.2 & 18 & 50 \\
\hline $564-2$ & 140.5 & 128.1 & 17 & 42 \\
\hline 564-3 & 140.4 & 130.6 & 19 & 53 \\
\hline
\end{tabular}

Table 19. Tensile data for linear friction welded Ti-6Al-4V alloy subscale performs. Tests performed per ASTM Standard E8. 


\section{Task 5 - Define a Viable Process}

Because we were unable to obtain the production Armstrong powder as planned for this project, we were unable to fully define a viable approach to NNS preform fabrication using this powder. We do know that Armstrong powders have low packing fraction, on the order of $6 \%$ density, which presents special problems in powder packaging and handling and in selecting a consolidation process to produce a fully dense billet for further processing. Powder could be consolidated by cold isostatic pressing followed by sintering (CIP + Sinter approach) (Figure 43). Or, powder could be attritted to increase packing density to a minimum of 50\%, and powder could be consolidated into billet by hot isostatic pressing (HIP) of powders loaded into a steel can. For either approach, geometry control of the billet is critical to achieving a process that maximizes yield of useful material and in turn keeps the cost of billet product as low as possible on a per pound basis. Billets would be further processed by hot working into conventional mill product forms such as rolled plate, rectangular hot rolled bar, or extruded shapes. These shapes would in turn serve as the building blocks for fabricating NNS machining performs by use of various joining methods.
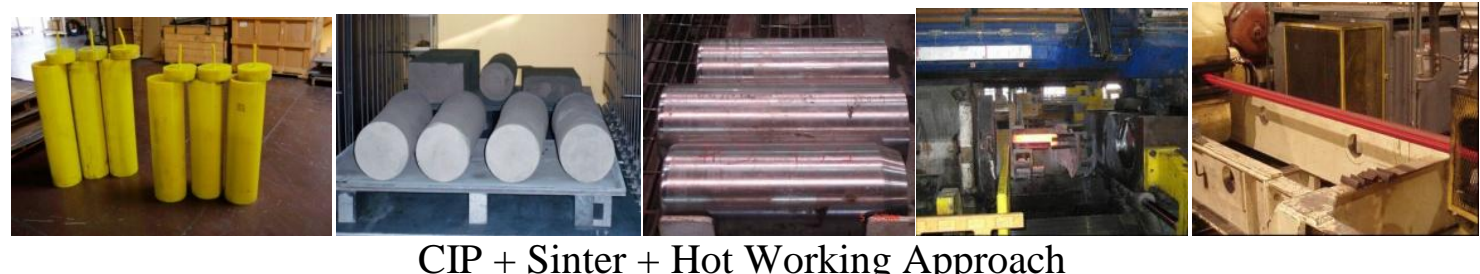

\section{CIP + Sinter + Hot Working Approach}
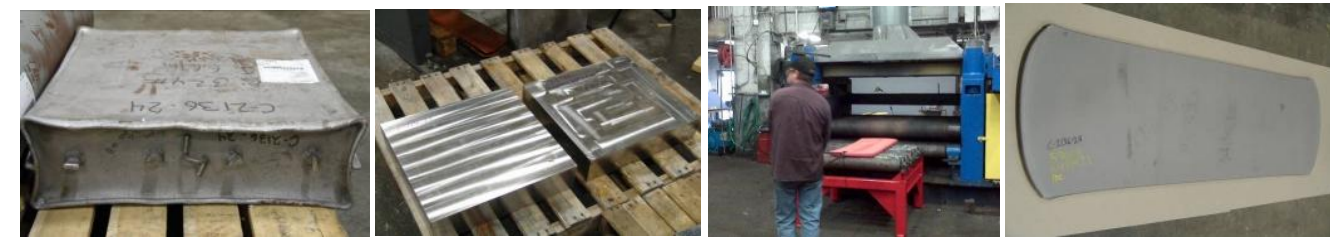

HIP + Hot Working Approach

Figure 43. Processing of titanium powders into mill products.

Based on the results of our technical feasibility studies, it appears that powder metallurgy based titanium materials are not fusion weldable. All fusion welds in all PM-based materials exhibit significant porosity and surface weld defects, which render the material unsuitable for structural applications. Results for the solid state joining process linear friction welding, however, are promising. Due to geometric limitations of friction joining equipment, manufacturing strategies would have to be developed specific to the particular part configuration of interest. Friction stir welding (FSW) could provide a more flexible process for solid state joining of large machining preforms. However, we were unable to perform any FSW experiments in this program due to unavailability of our FSW unit.

Finally, the mechanical properties of NNS performs fabricated from production Armstrong Ti6Al-4V powders will need to be established in order to establish the viability of the NNS approach. Properties of interest include the properties of mill product forms such as plate and bar stock, as well as those of solid state joined preform assemblies. A post-join heat treatment 
that optimizes a balance of engineering properties will need to be established. And, design allowables will need to be established to provide statistical confidence in material behavior to support design activities and enable qualification and certification of titanium components produced from these preforms.

\section{BENEFITS ASSESSMENT}

Successful development of the proposed technology will have numerous environmental benefits. With regards to commercial aircraft, the environment benefits from increased applications of titanium. Titanium has outstanding resistance to corrosion in a wide range of aggressive conditions, which eliminates or substantially reduces metal loss and any energy inputs for repair or replacement. The low density reduces fuel consumption in aircraft, and reduces shortfalls in payload, range, speed, and other critical factors. In addition, titanium can be recycled to ensure maximum recovery of every form of reverted material and scrap, with an overall reduction of energy input to sustain the metal supply.

Due to the increased use of lightweight composite materials and titanium structure, new engine technologies, more efficient systems, and modern aerodynamics, the Boeing 787 delivers significant environmental benefits. The primary direct greenhouse gas emissions of aircraft are carbon dioxide $\left(\mathrm{CO}_{2}\right)$ and water vapor $\left(\mathrm{H}_{2} \mathrm{O}\right)$. Other emissions are oxides of nitrogen $\left(\mathrm{NO}_{\mathrm{x}}\right)$, particles containing sulphur oxides $\left(\mathrm{SO}_{\mathrm{x}}\right)$, and soot. The amount of aviation fuel burned and the total emissions of $\mathrm{CO}_{2}, \mathrm{NO}_{\mathrm{x}}$, and water vapor alter the concentration of ozone $\left(\mathrm{O}_{3}\right)$ and methane $\left(\mathrm{CH}_{4}\right)$. These emissions may trigger the formation of condensation trails and increase cirrus clouds, both of which may contribute to climate change. Specific regulations have been established for future aircraft, using a complex formula based on the thrust ratings of an airplane's engines. Increasing use of advanced materials such as composites and titanium in commercial aircraft results in improved fuel efficiency and a reduction in harmful emissions. For example, the 787 achieves $20 \%$ better fuel efficiency, with a $20 \%$ reduction in carbon emissions and a reduction in nitrous oxide emissions of over $30 \%$ compared to the older 767 , satisfying the regulations being incorporated by the International Civil Aviation Organization (ICAO) Committee on Aviation Environmental Protection (CAEP).

The emerging conversion processes such as Armstrong and Cambridge are also more environmentally friendly processes overall, requiring less energy for titanium extraction. The near net shaped manufacturing process utilizing low-cost titanium powders enabled by these new metal extraction processes would also be more environmentally friendly. Since less material is used, less scrap is generated. Since machining requirements are reduced by up to $80 \%$, significantly less electricity, machine tools, and cutting fluids are required for fabrication.

The potential benefits of the technology should also be considered in terms of the anticipated market for commercial aircraft over the next 25 years. As previously noted, the use of titanium in commercial aircraft has increased steadily over the last 50 years. Today, over 58 tons of titanium are needed to build a single Boeing 787, and almost 900 of these aircraft have been sold since introduction. The market for large twin-aisle aircraft such as the 787 over the next 25 years has been estimated at almost 7,000 airplanes, having a market value of $\$ 1.5$ trillion dollars. 
Assuming that new aircraft currently under development, such as the Airbus A350 follow similar design trends in the use of advanced structural materials, the titanium requirements for the commercial aircraft industry could approach 2 billion pounds over the period. In addition, as composite technology transitions into the next generation of smaller, single-aisle aircraft such as the 737, with a market estimated at almost 20,000 aircraft over the next 25 years worth an additional \$1.36 trillion dollars, titanium requirements could grow even further. Our analysis also does not include military aircraft, which use large amounts of titanium but which have smaller rates of production, and which would also benefit from the technology. Using existing titanium technology, with its characteristic high buy-to-fly ratios, those 2 billion pounds would be used to produce approximately 250 million pounds of finished titanium components, along with 1.75 billion pounds of titanium scrap mostly in the form of machining chips. Costs associated with the large excess of material needed, together with the machining costs to convert that material into finished products, place a significant burden on the commercial aircraft industry.

\section{COMMERCIALIZATION}

The powder metallurgical processes used to convert titanium powders into mill product forms such as plate, bar, and extrusion, are existing commercial processes with a supply chain already in place. The key element that does not currently exist on a reliable commercial basis is the new energy-efficient conversion process capable of supplying affordable titanium powder. ITP is currently working to bring their new Armstrong powder production plant in Ottawa, IL, online later this year. While they face technical challenges in establishing a commercial Armstrong process, these challenges appear to be solvable. If powder in sufficient quantity is made available, then the key step to using the current titanium powder metallurgy supply chain will be addressing the characteristic low packing fraction of as-produced Armstrong powder. The existing supply chain is capable of producing material in the quantities needed to achieve the energy and cost benefits identified in Task 2. Given Armstrong powder of sufficient quality, the processing strategies to convert that powder into useful products that meet the requirements for aerospace structures are available and have been demonstrated for conventional titanium powders (hydride/dehydride and sponge-fines based powders). Our objective will be to develop the technology when powder is available, and qualify it for use in commercial aircraft. We will include it in a portfolio of manufacturing approaches for titanium components. Then, individual approaches may become more or less attractive depending on the market conditions for titanium at any point in time.

\section{ACCOMPLISHMENTS}

$\checkmark$ Completed analysis of the energy and cost benefits of near net shape titanium technology for commercial aircraft;

$\checkmark \quad$ Identified opportunities for near net shape titanium technology for over $60 \%$ of titanium airframe structure in the modern commercial aircraft;

$\checkmark$ Determined that solid state joining is likely an enabling technology for fabrication of near net shape machining performs from powder metallurgy mill products; 
$\checkmark$ Established cost targets for near net shape machining performs.

\section{CONCLUSIONS}

Conversion processes such as the Armstrong and Cambridge processes are not sufficiently mature to consider for commercialization at this time. The Armstrong powder production facility being constructed by ITP in Ottawa, IL, is not yet online. A variety of processing issues are currently being addressed, and we believe that all of these technical issues are solvable. Some effort remains to define a baseline process that addresses the characteristic low packing fraction of this material and the impact of powder characteristics on shipping and handling, and efficient conversion to useful product. And, once a baseline process is established to convert the powder made by this process into usable mill products with reliable properties for use in commercial aircraft, additional effort will be required to qualify the material for service in commercial aircraft structural applications. Similarly, a sufficient quantity of powder derived from the Cambridge process is needed to define a baseline process for the conversion of powder into useful products. The benefits for affordability and manufacturing efficiency of using powder-based near net shape preforms are significant, but process development on a commercial level must be performed to establish realistic cost models for the approach.

\section{RECOMMENDATIONS}

Further work is needed with powders produced from emerging conversion methods such as the Armstrong process. While conversion of titanium powders to mill products have been demonstrated for conventional powder such as $\mathrm{HDH}$ and $\mathrm{BE}$ materials, Armstrong powder presents special challenges due to the low packing fraction of the powder. A baseline processing approach needs to be developed that achieves affordable products to enable the NNS approach to achieve the planned cost savings for finished titanium parts. And, a significant test program must be performed on commercial material produced using that baseline process to provide statistically-based design allowable mechanical properties to support design activities. There is also a need to develop approaches to rapidly qualify and certify new materials for service that reduces the time and resources required by the current building block approach.

\section{REFERENCES}

Reference 1: R. Kirchain and R. Roth, Report: The Role of Titanium in the Automobile, Camanoe Associates, Cambridge, MA, July 2002.

Reference 2: Kraft, E. H., Summary of Emerging Titanium Cost Reduction Technologies: A Study Performed for the U.S. Department of Energy and Oak Ridge National Laboratory, Vancouver, WA.: EHK Technologies, January 2004.

Reference 3. W. Peter, S. Borys, et al, Solid State Processing of New Low Cost Titanium Powders Enabling Affordable Automotive Components, $13^{\text {th }}$ Diesel Engine Efficiency \& Emissions Research Conference (DEER), August 2007. 